\title{
ملضص البحث
}

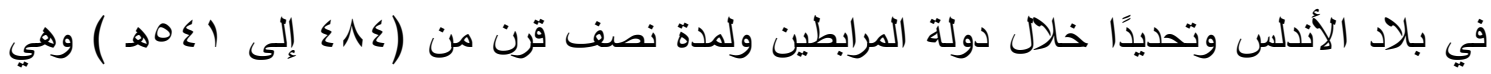

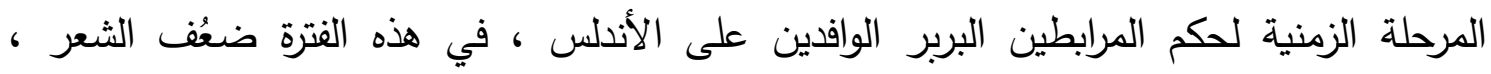

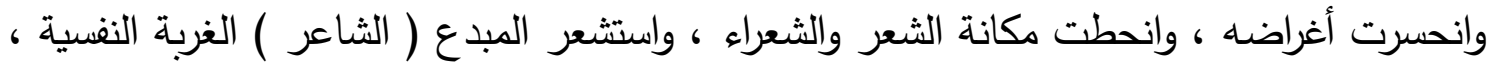
وأحس بشرنقة الذات العاجزة عن مواصلة الإبداع - خاصة بعد عصر الطوائف بإلقعه الفني ، وتوهجه

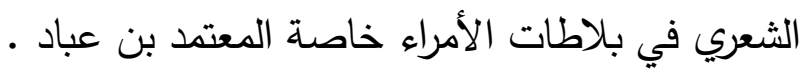

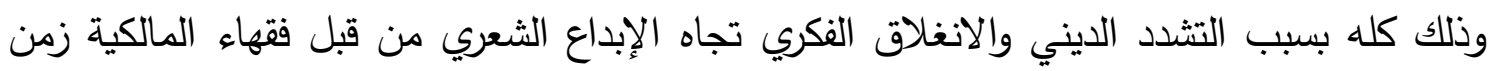

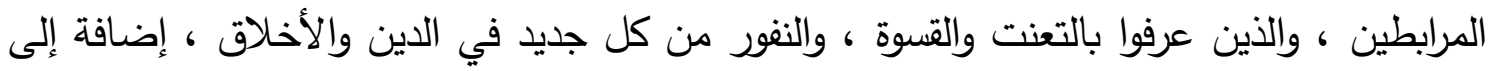

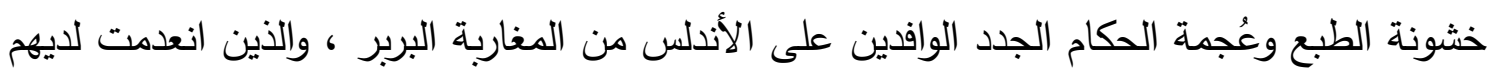

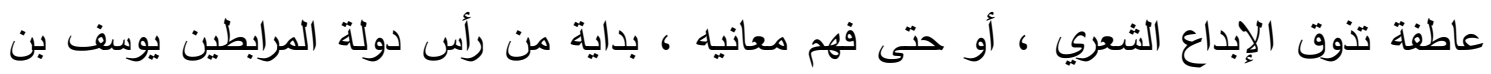
تاشفين ، وكل رجال دولته الذين ولاهم أمارات الأندلس. وقد ظهر ذلك الفكر المنغلق حيال الإبداع الثعري بوضوح في كتاب مثل خلاصة الإنه الانغلاق والتثدد

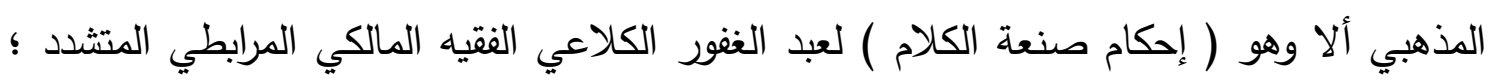

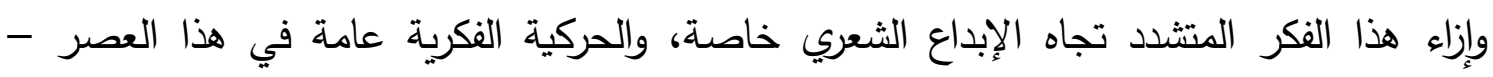
يَصدق الدكتور / محمد عبد الله عنان إذ أطلق عليه (عصر الديكتاتورية الدينية ) .

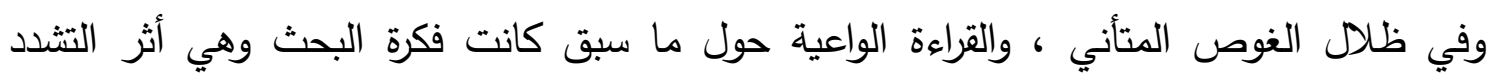

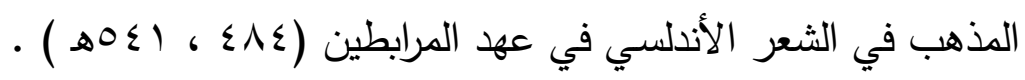

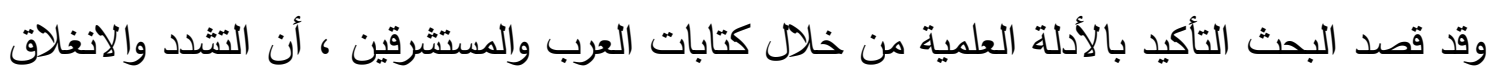
الفكري من قِبل فقهاء المالكية ، قد ظهر بوضوح وأثر على الثعر والثعراء زمن حكم المرابطين للأندلس ، مما أدى إلى ضعف فئ الثعر وانحطاطه وانحساره .

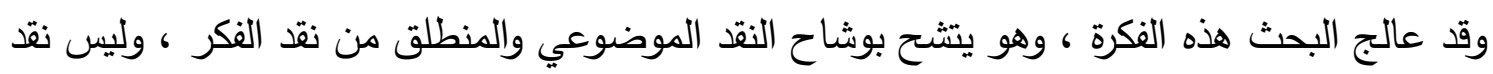

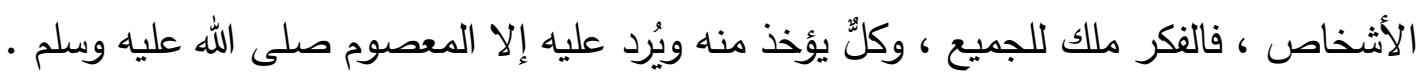
الكلمات المفتاحية : التثدد المذهبي - الثعر الأندلسي - عهد المرابطين -

الباحث/ محمد طه صالح خضر 


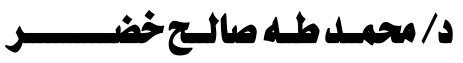

\section{Research Summary}

In the country of Andalusia, specifically during the Almoravid state and for half a century from ( $\leqslant \wedge \varepsilon$ to $0 \leqslant) A H$ ), which is the time period for the rule of the Almoravids, the Berbers who came to Andalusia. The self incapable of continuing creativity - especially after the era of cults with its artistic brilliance and poetic glow in the courts of princes, especially al-Mu'tamid ibn Abbad.

All this is due to religious strictness and intellectual isolation towards poetic creativity on the part of the Maliki jurists at the time of the Almoravids, who were known for their intransigence and cruelty, and aversion to everything new in religion and morals, in addition to the harshness of nature and the arrogance of the new rulers who came to Andalusia from the Moroccan Berbers, who had no passion for a taste of creativity. Al-Sha'ari, or even understood its meanings, starting with the head of the Almoravid state, Yusuf bin Tashfin, and all the men of his state who appointed the principalities of Andalusia to them.

This closed thinking about poetic creativity was clearly shown in a book such as the summary of closing and doctrinal extremism, which is (Ikmaan craftsmanship of speech) by Abd al-Ghafoor al-Kala'i, the hard-line Maliki jurist, al-Murabit. And in the face of this strict thought towards poetic creativity in particular, and intellectual movement in general in this era - Dr. / Muhammad Abdullah Annan is right when he called it (the era of religious dictatorship).

In the shadows of careful diving, and conscious reading about the foregoing, the idea of the research was the effect of doctrinal strictness in Andalusian poetry in the era of the Almoravids $(\varepsilon \lambda \leqslant, 0 \leqslant 1 \mathrm{AH})$.

The research aimed to confirm with scientific evidence through the writings of Arabs and orientalists, that strictness and intellectual isolation by the Maliki jurists, has clearly appeared and affected poetry and poets at the time of the rule of the Almoravids of Andalusia, which led to the weakness of poetry and its decline and decline.

The research has dealt with this idea, and it is covered with the veil of objective criticism and stemming from criticism of thought, not criticism of individuals, for thought belongs to everyone, and everyone is taken from it and replied to it except for the infallible, peace and blessings of God be upon him.

Keywords:

Doctrinal extremism - Andalusian poetry - Almoravid era. researcher 
الحمد الله رب العالمين والصلاة والسلام على أشرف المرسلين ، سيدنا محمد سلى الله عليه وسلم

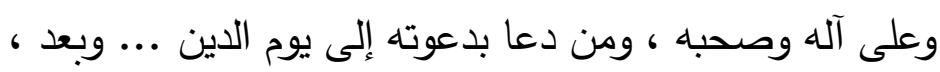

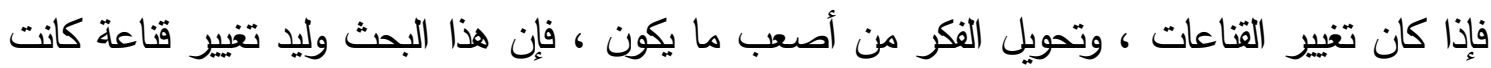

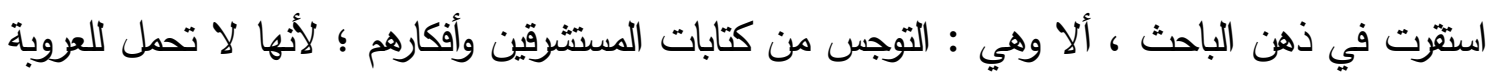
والإسلام إلا البغض والحقد والكراهية والعنصرية ... ولكن في مؤتمر ( أعلام العربية في مرايا المستشرقين )

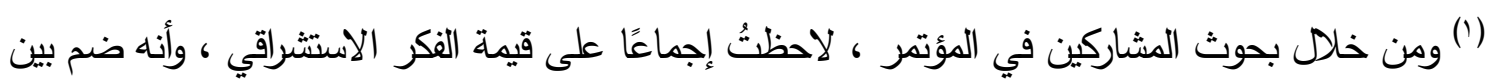

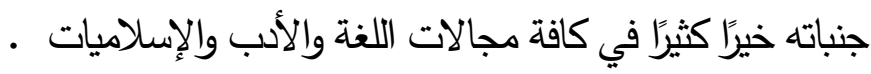
وقد شُغلْتُ منذ زمن بالتراءة في الشعر الأندلسي في مرآة الاستشراق الإسباني ، فلفت نظري ما كتبه غرسيه

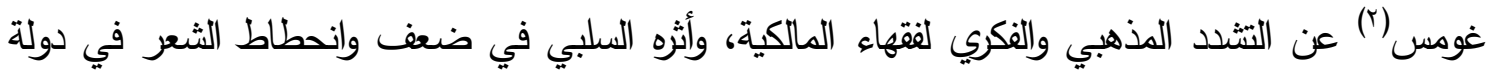

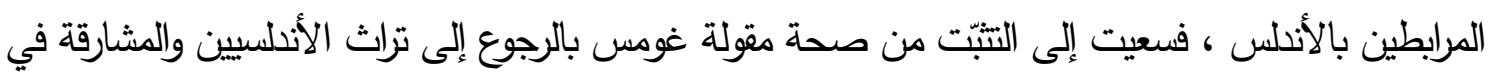

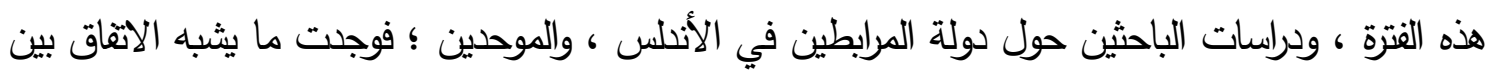

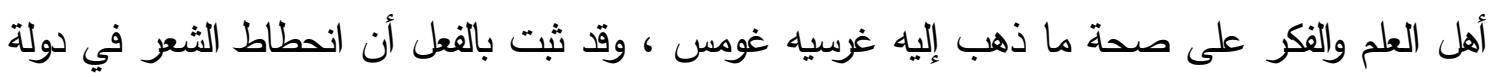

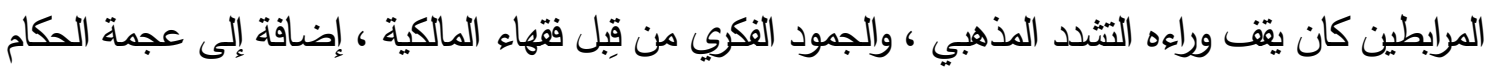

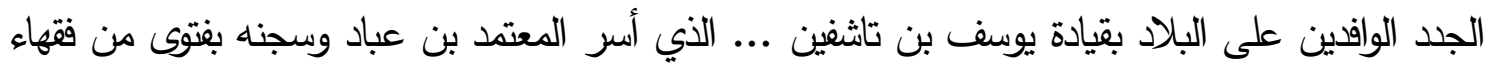

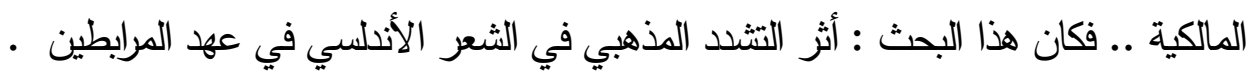

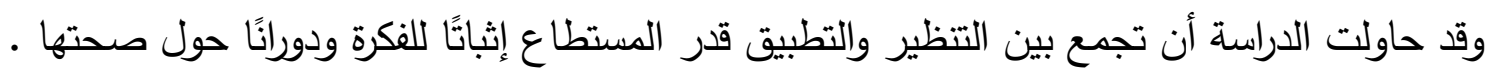

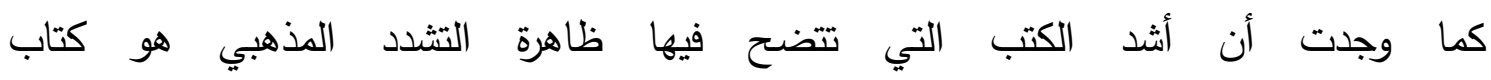

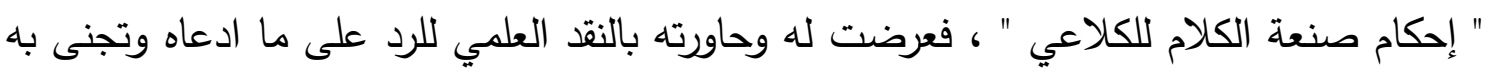
على الثعر كما سيتضح إن شاء الله . ثم تعرضت لتداعيات هذا التثدد وأثره في الثعر والثعراء ، كما بينت على أثر هذا التشدد والجمود

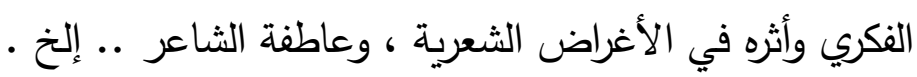
ولقد كان منهجي الذي يتقق وطبيعة الدراسة هو المنهج الاستقرائي ، إضافة إلى المنهج التحليلي

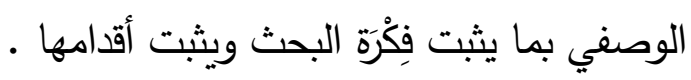
وعليه فقد جاء البحث في مقدمة ، وتمهيد ، وثلاثة مباحث ، وخاتمة ، ثم فهرسين أحدهما للمراجع

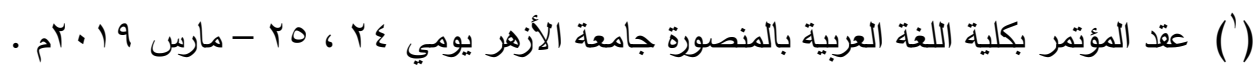

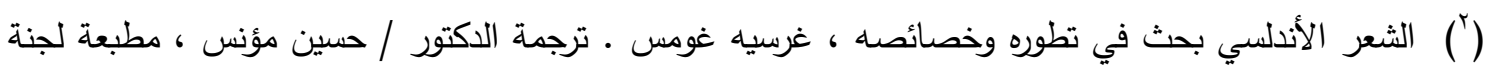

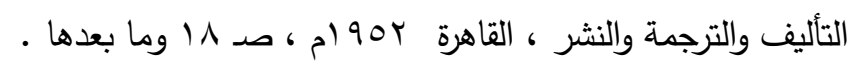


والآخر للموضوعات .

- ففي المقدمة أشرت إلى منبع الفكرة وانطلاق شرارتها في نفس الباحث ، ومنهج البحث . - وجاء التمهيد - ليؤصل نظريًا لفكرة التثدد والجمود في ظل سيطرة فقهاء المالكية على مقاليد

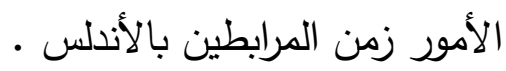

- ثم جاء المبحث الأول بعنوان / الكلاعي ( وكتابه إحكام صنعة الكلام ) نموذجًا تطبيقيًا : وتحته ستة مطالب :

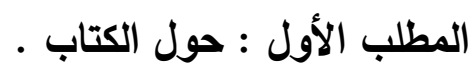

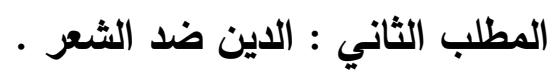

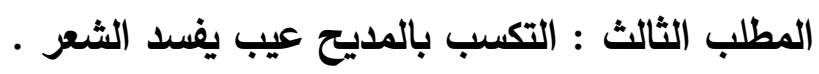

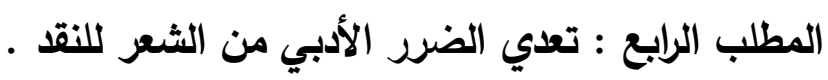
المطلب الخامس : الادعاء بتنافر الثعر والكتابة .

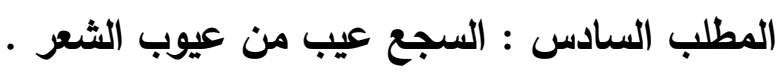
- وأما المبحث الثاني : فيحمل عنوان : تداعيات التشدد المذهبي على على حركية الثعر • وتحته أربعة مطالب : المطلب الأول : الثعراء وحس الاغته : المطراب .

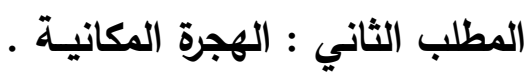

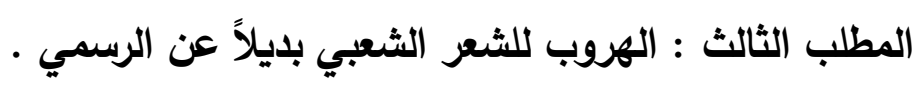

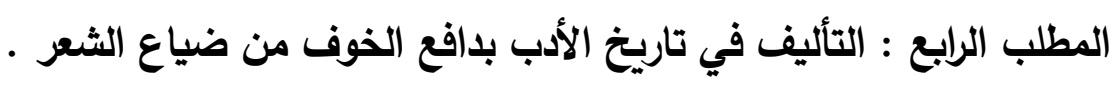

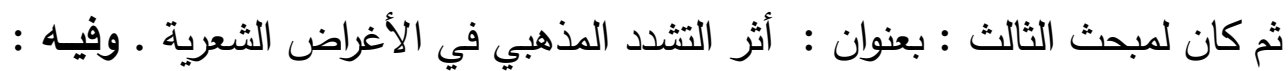
مدخل : المطلب الأول : شعر المديح وأغراض أخرى .

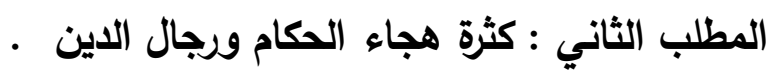

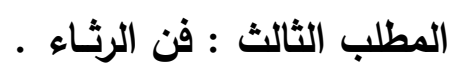
المطلب الرايع : وصف الطبيعة .

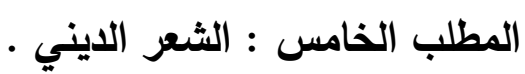
ثم أعقبت ذلك بخاتمة متضمنة أهم نتائج البحث ، ثم فهرس المصادر والمراجع ، وآخر للموضوعات. 


\section{تمهيــــ \\ التنظير النقدي للفكر المتثدد في دولة المرابطين}

$$
\text { - }
$$

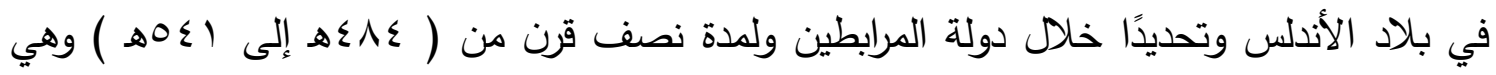

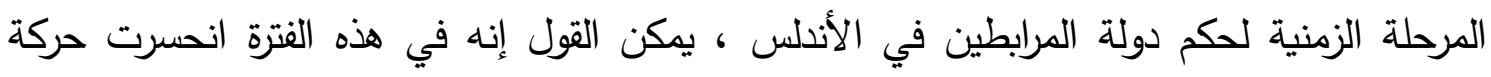

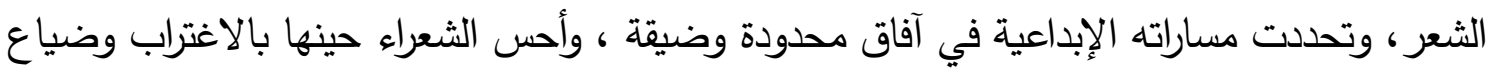

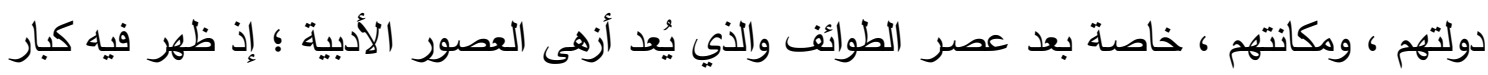

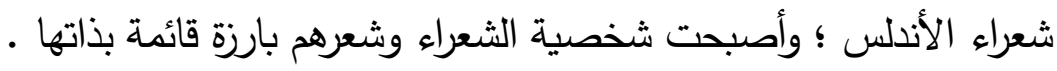
ومرد الحكم السابق يرجع إلى أمرين : أولهما :- التشدد الديني من فقهاء المالكية في دولة المرابطين، إذ اتسموا بالتعنت والقسوة والنفور من

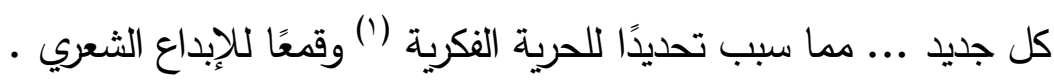

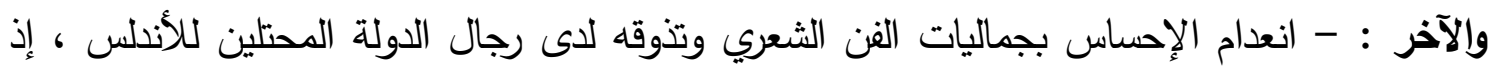

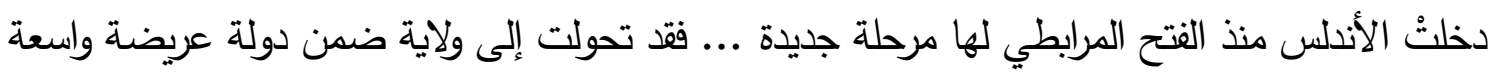

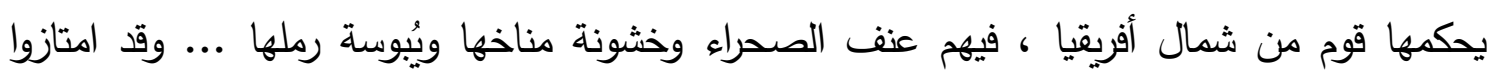

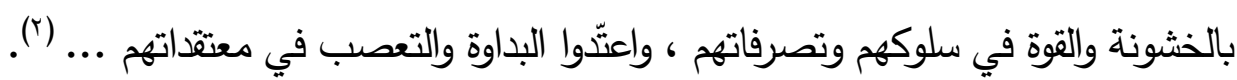

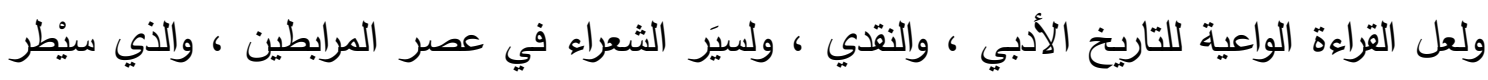
عليه فقهاء المالكية لتؤكد أن هذه الدولة كانت :

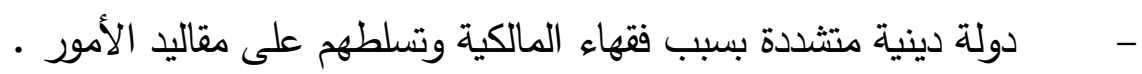
دولة حربية عسكرية ظلت في جهاد مستمر وحروب دائمة وهو ما ينسجم مع طبيعة الفاتحين

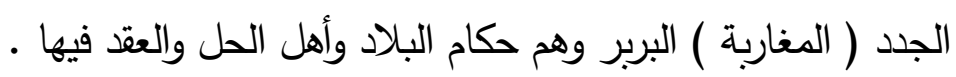

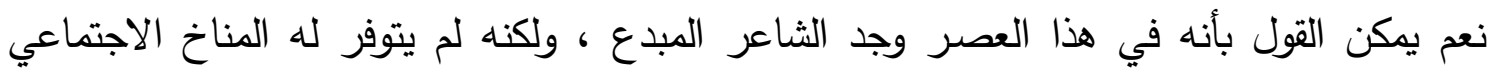
للإبداع،

(') الثعر في عصر المرابطين والموحدين بالأندل، د/محم مجيد السعيد، الدار العربية للموسوعات ، بيروت ، طץ ،

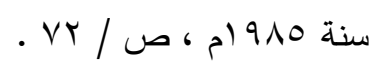

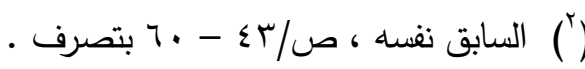




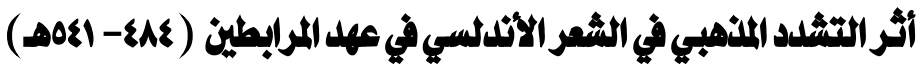

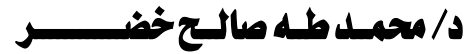

وهنا نتفق مع الناقد الإنجليزي أرنولد(') في قوله : ( إن الرجل المبدع لا يكفي بدون العصر ) (ז) فإذا كان النقد السياقي في قراءة النص الثعري يؤكد أنه ( لا يمكن أن يتم خلق العمل الفني العظيم إلا بتوفر عاملين : الطاقة الإبداعية الكامنة في الفنان ، والطاقة الثقافية الكامنة في العصر ، وأنه لابد للطاقتين أن يلتقيا لينتج عن التقائهما الأدب العظيم ) () ، فإن البحث ليؤكد أنه بقدوم المرابطين الأندلس هبطت راية الشعر ، وانحسرت أوديته وتُلَّتُ عروش الثعراء ، وتأخرت طبقتهم بسبب : تسلط الفقهاء وتثددهم المنغلق ، وسيطرتهم على مقاليد الدولة ورجال السياسة . خشونة الطبع وانعدام الذوق الإبداعي للشعر عند المرابطين المحتلين للأندلس • فقد قامت دولة المرابطين منذ بدايتها الأولى على أساس جهود ثلة من فقهاء المالكية بالمغرب الإسلامي، فهم الذين نظروا للمشروع الإصلاحي ، ومهدوا السُبل لتحقيقه على مسرح التاريخ داخل الأندلس... ولذا استمرت دولة الأندلس قائمة على أساس فقهي وخاصة في دولة المرابطين. وعلى طول العصر ، ازداد منهج الفقهاء تثددًا بقوة مكانتهم السياسية ، فقد ثبت هذه الطبقة أقدامها ووققت شامخة تأمر وتتهى ، وتسيطر وتوجه ، وبالجملة فالفقهاء هم الذين حكموا الأندلس زمن المرابطين مختفين وراء لثامهم وتزمتهم الديني (ء). بواكير الظاهرة :

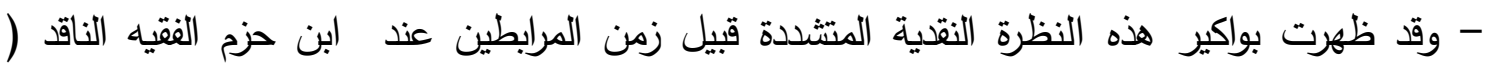
ت 07 §ه ). والذي أعتقدها الثرارة الأولى لتأسيس هذه الفكرة . فقد نظر للنص الثعري من منظور ديني فقهي متشدد ، ويكأني به أمام مسائل فقهية قام بتطبيق أحكام أصول الفقه عليها ، وليس إبداعًا شعريًا نابعًا من إلهام وعاطفة دئة ...

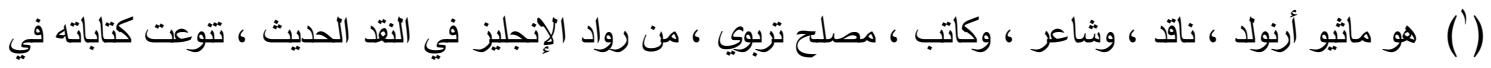

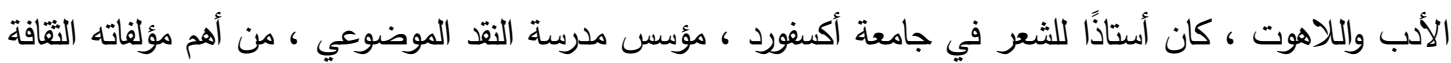

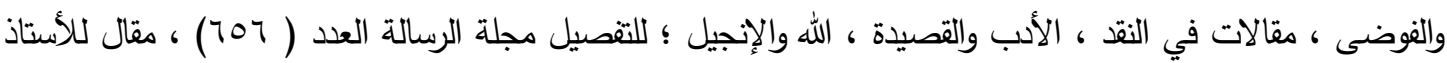

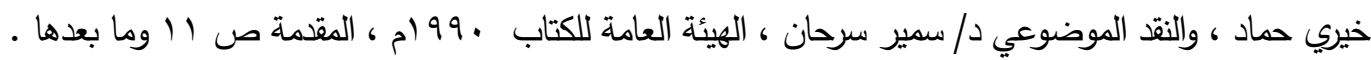
وكذا الموقع الالكتروني . wikllar. M.wlkpoor

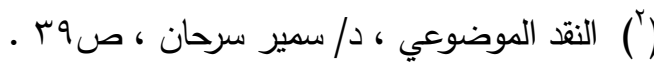

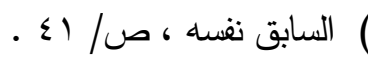
(راسات أدبية في الثعر الأندلس ، د/ سعد شلبي ، دار نهضة مصر - الفجالة - ص/ 10\% بتصرف .

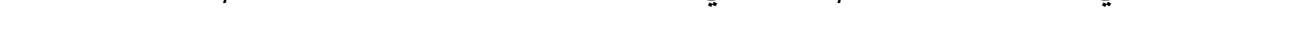


( أ ) فمنه المحرم (') وهي :

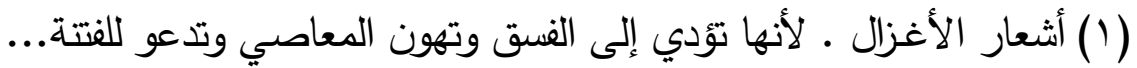
(Y) أشعار التصعلك وذكر الحروب كثعر عنترة - لأنها تثير النفوس وتهيج الطبيعة وتدعو للظلم

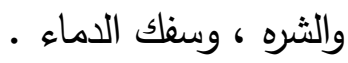
(r) أشعار التغرب وصفات المفاوز والبيد والمهامه لأنها تسهل على الناس التحول والتغرب ، وتتشب

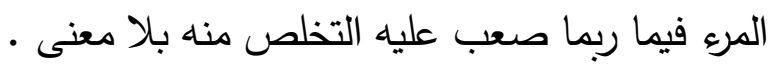
(؛) الهجـاء • وهو أفسد الضروب السابقة لأنه يمزق الأعراض ويذكر العورات وينتهك حرمات الآباء والأمهات ، وفي هذا حلول الأمار في الدنيا والآخرة .

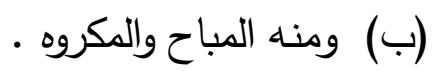
وهما المدح والرثاء لأن فيهما ذكر فضائل الميت والمددوح ، ولأن أكثر ما فيه كذب ولا خير في الكنب. وأخيرًا فإن رواية الثعر والإكثار منه كسب غير محمود لكونه طريقًا للباطل والفضول لا طريقًا للحق والفضائل (「) هذا - ولا شك - تأسيس مبكر لنظرة فقهية منغلقة ، لا تتماشى وطبيعة الإبداع الثعري، والذي هو في

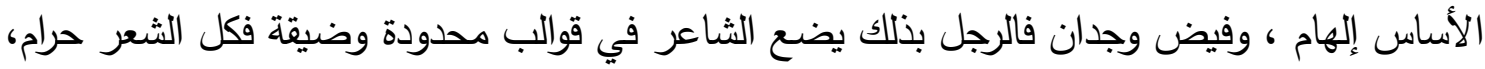

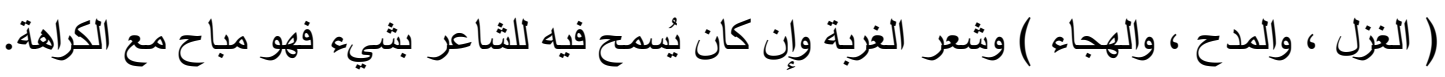

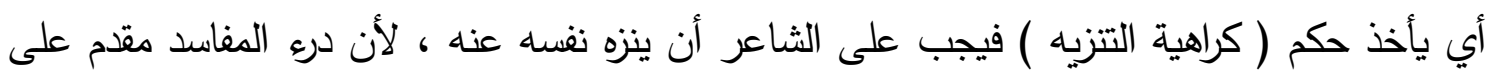
جلب المصالح كما تقول القاعدة الأصولية عند الفقهاء.

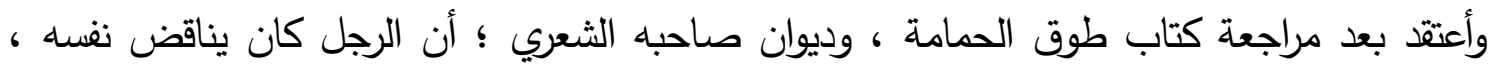

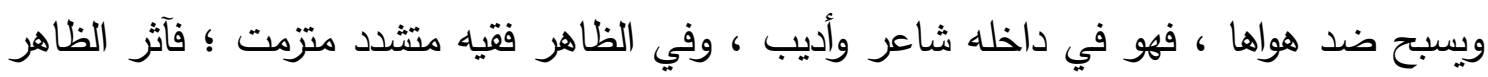
وأخفى الباطن ، فعاش بينه وبين نفسه في صراع (الطبع والدور ) (r) أو ثنائية العقل والعاطفة

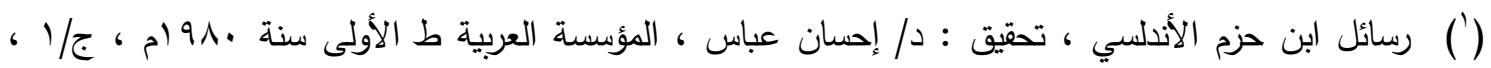

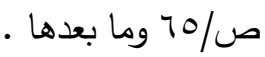

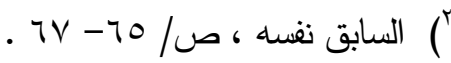

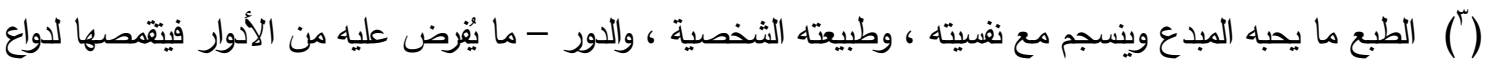

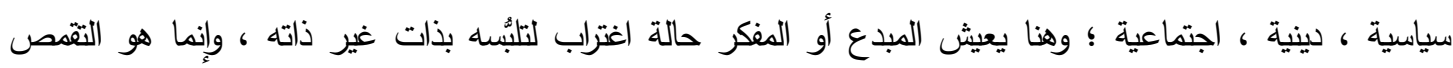

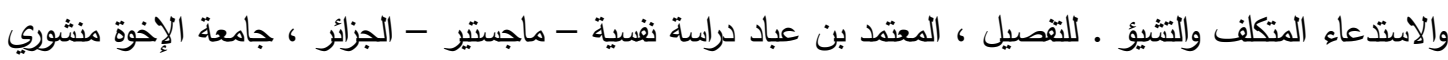

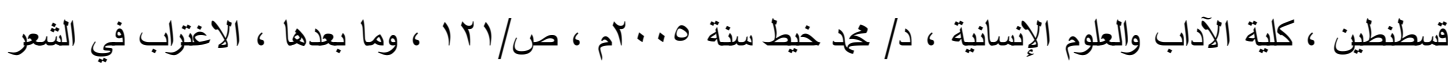

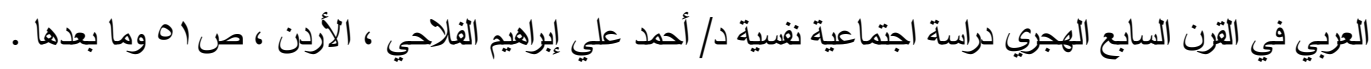




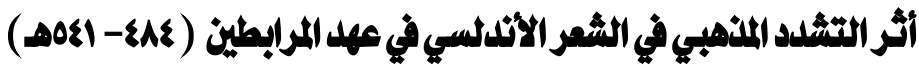

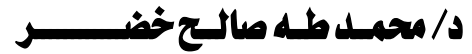

المتضادة التي أحيانًا ما تسيطر على أهل الإبداع والفكر بسبب الغربة النفسية والاجتماعية ؛ كما وجدناها عند الثريف الرضي ، وأسامة بن منقذ ، وأبي فراس الحمداني، فالظاهر الطموح والثجاعة والباطن الانكسار والقلق النفسي • - وهنا تتأتى عملية القهع الفكري ، والقهر السلطوي للإبداع الشعري " من أصحاب الموقف الأخلاقي من المفكرين والنقاد - إزاء الفن - الذين يوجهون إلى الفن عامة وإلى الأدب خاصة تهمة خطيرة ، مفادها أنه من خلا تأثيره في النفس الإنسانية قادر ، إذا هو خرج عن محوره الطبيعي ، أن يفسد الأذواق ، ويحطم القيم، ويكون أداة تخريب في بنية المجتمع الصالح ، ومن ثم يكون مسئولاً - ضمنيّاً - عن انحطاط الحضارة وانهيارها " ('). الأمر الذي يؤكد على ضعف الثعر وانحساره لخضوعه للرقابة الأخلاقية والفقهية على امتداد العصر الأندلسي ، وقد لاحظ د/ إحسان عباس ذلك إذ يقول: " إنني أقرر منذ البدء أن الشعر الأندلسي لم يفقد صلته بالتوجه الأخلاقي في أية خطوة أو مرحلة .. وقد كان لهذا التيار النقدي الأخلاقي آثار يجب ألا

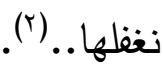
وقد ظهرت هذه الآثار فيما بعد بالسلب وآتت أُكلها ؛ إذ ساد هذا الفكر النقدي المتعسف بعد ابن حزم وسرى سريان النار في الهشيم في دولة المرابطين وعشش وفرّخ الأمر الذي أضر بالشعر والشعراء ، وقد ظهر ذلك عند أدباء هذا العصر من أمثال:

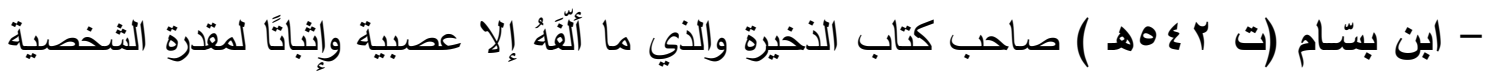

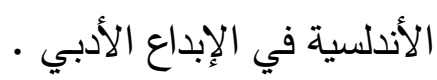
إذ غاظه ما يصنع الأندلسيون من تقديس لأدب أهل المشرق العربي ، ولذا وجدناه يُعرِض بالأدب المشرقي " إذ كل مرددٍ ثقيل ، وكل متكررٍ مملول ، وقذّ مجتْ الأسماع يا دارميةٌ ، ... ولخولة أطلدل، ومجت قفانبك (r) (ب) وعلى منهج النقد الفقهي الديني المتثدد نراه يتابع ابن حزم إذ يستكر شعر المديح قائلاً عنه : " لم أرضده مركبًا ، ولا اتخذته مكسبًا ، ولا ألفته مثوى ولا منقلبا"(ء).

(') دراسات في الأدب الأندلسي ، د/ إحسان عباس ، د/ وداد القاضي ، د/ ألبير مطلق ، طبع الدار العربية للكتاب ، لبيا

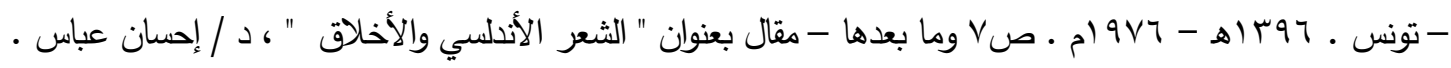

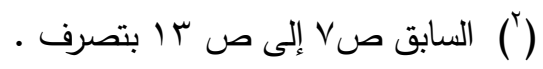

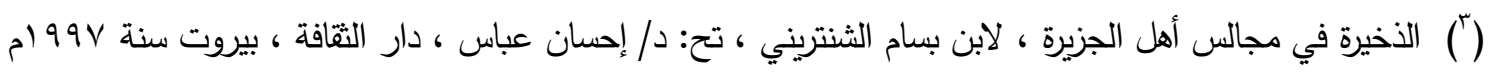

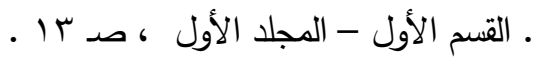

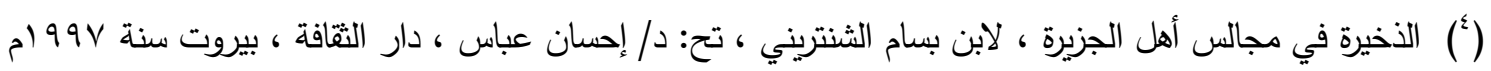

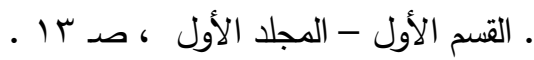


وكذا رفض شعر الهجاء إذ يقول ( وقد صُنتُ كتابي هذا عن شين الهجاء ، وأكبرته أن يكون ميدانًا

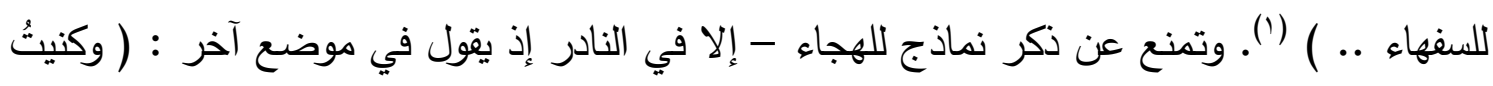

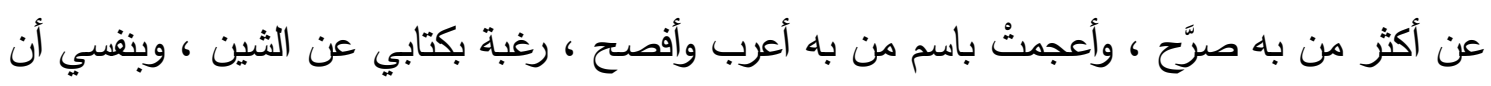

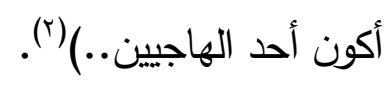
وإنا لنعجب له .. فقد نقل النص الترآني كلام الكفار من منطلق أن نقل الكفر ليس بكفر ؟! وفي ظني

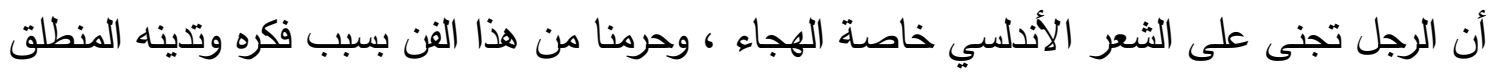

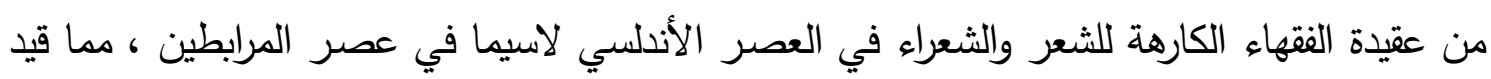

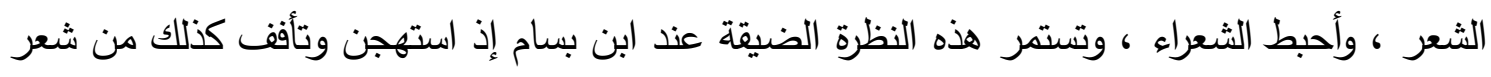

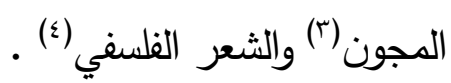
- - ابن السيد البطليوسي : والعجب كل العجب أن نجد هذا النهج النقدي الماضي على منهج

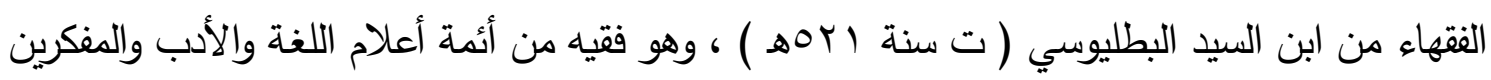

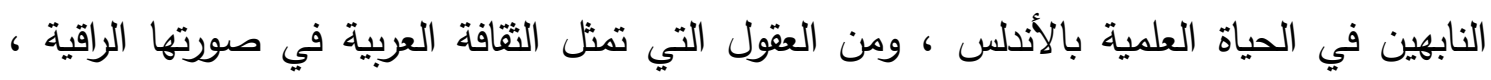

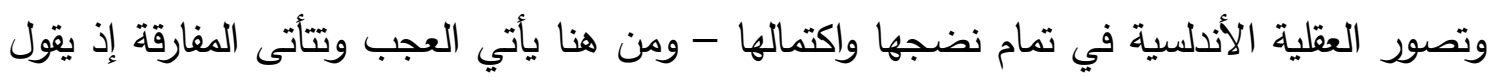

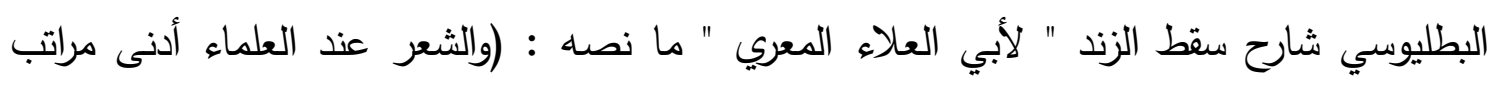

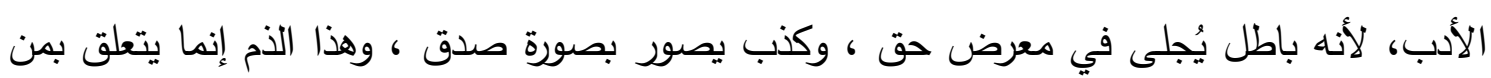

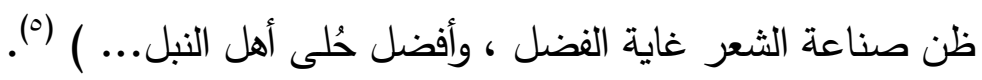

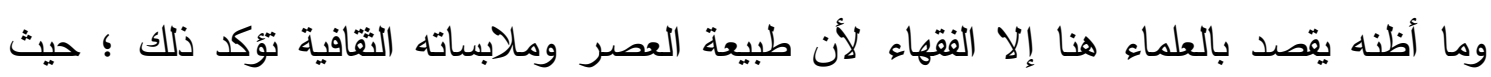

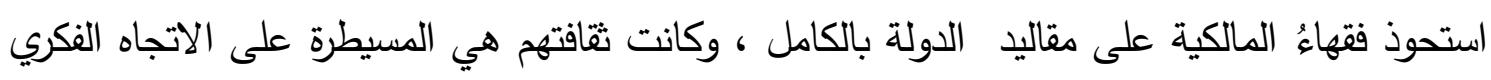
في عهد المرابطين سواء في أمور الدنيا ، أو الجانب الروحي من إصدار الفتاوى في القضائا الفيا القانونية

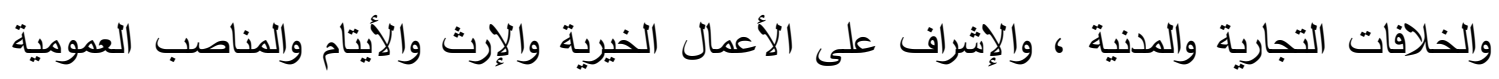

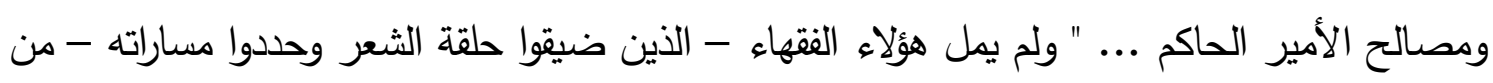
تكرار أن بِلمهح مما يُقرب إلى الله ، لكنهم وبكل بساطة كانوا يُسنِّرون هذا العلم لخدمة مصالح الأمير

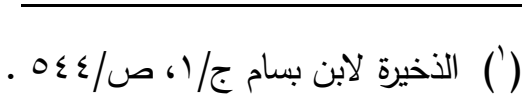

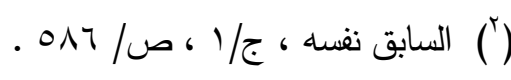

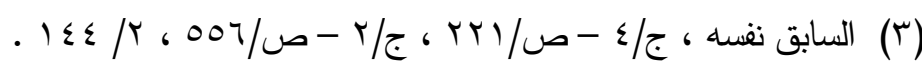

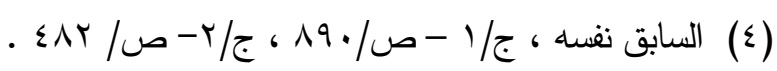

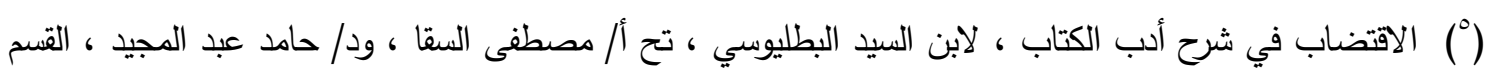

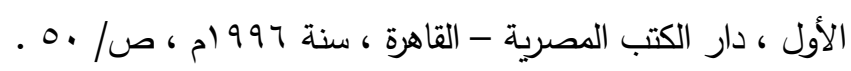




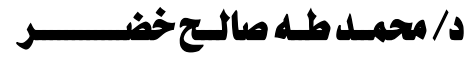

الذي يعملون تحت سلطته ، والذي لم يبخل عليهم في المقابل بتعيينهم في المناصب الرفيعة ، وهكذا تحول الفقه معهم إلى وسيلة يكرسون بها الوضع القائم ، ... " ( ) . وقد طال هذا التعصب والفكر المنغلق من فقهاء المالكية كل ما في الحياة بما في ذلك الإبداع الشعري ، فضعف الثعر وضاعت دولة الثعراء لتسلط الثقافة الفقهية على عهد المرابطين على الثعر تسلطًا

جعل الثعراء في حالة من الذهول والحيرة ... (؟).

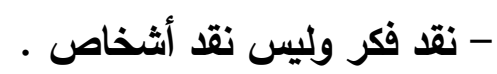
هذا - وإذا كانت الفكرة المطروحة هنا تقصد التأكيد على انحسار وضعف الثعر أيام المرابطين بسبب تثدد فقهاء المالكية وموقفهم من الثعر والثعراء ، وبسبب بداوة وخشونة طباع رجال الدولة وهم من البربر المغاربة المحتلين لبلاد الأندلس في عهد المرابطين ؛ فإن الباحث ليؤكد أنه ينقد فكرًا ، ولا ينقد أشخاصًا أشنا لأن الفكر ملكية عامة ، خاضع للقبول أو الرفض . وإذا كان العلم ميراث العلماء ، وهو رحم بين أهله ولنا في السابقين قدوة ، فإن الباحث ليقتفي أثر عالمين كبيرين نقدوا الفكر ، وأثبتوا أن ذلك لا يقدح في أحد، ولا ينقص من قدر من نقدوهم ، وأما أولهما فهو ابن قتيبة الدينوري (ت TVT Tه) في التتبيه على مآخذه على أبي عُبيد القاسم بن سلام

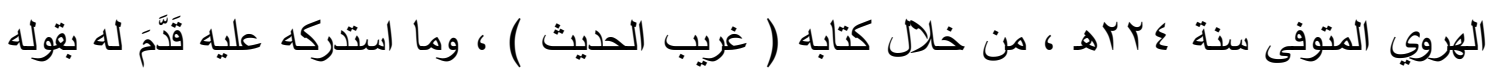
مُتَحَليَّا بأدب العلماء: ( ... قد يظن من لا يعلم من الناس ولا يضع الأمور في مواضعها أن هذا

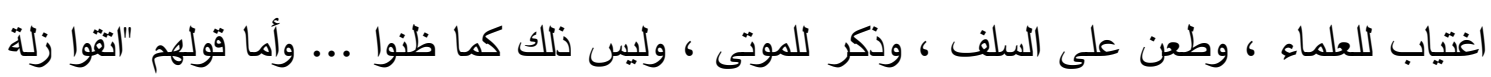
الصالح " فزلة العالم لا تعرف حتى تُكشف ، وإن لم تعرف هلك بها المقلدون ولا نعلم أن الله عز وجل أعطى أحدًا من البشر موثقًا من الغلط وأمانًا من الخطأ ، بل وصل عباده بالعجز وقرنهم بالحاجة ...

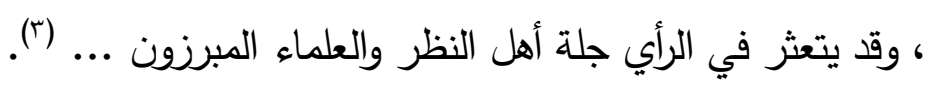
وما أظن ذلك من ابن قتيبة إلا ليدفع عن نفسه مظنة الطعن في العلماء - وأن ما اجتهد فيه واستدركه على أبي عبيد القاسم ابن سلام هو نقد للعلم والفكر - وليس للأشخاص ، وهذا هو ما قصد البحث إثباته هنا

(') (التاريخ السياسي للامبراطورية الموحدية ، للمستشرق الأسباني أمبر وسيو هويثي ميراندا ، ترجمة : عبد الواحد

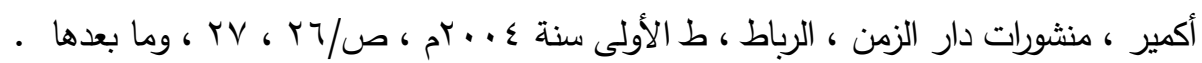

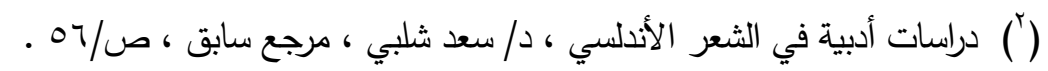

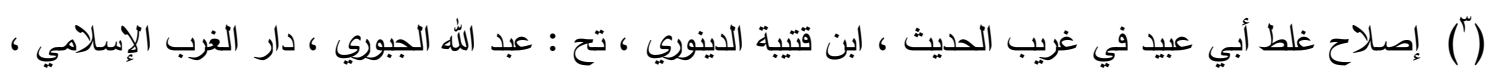

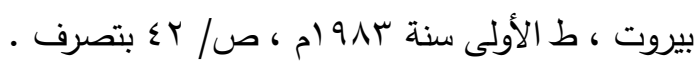


وأما ثانيهما فهو ابن السيد البطليوسي الأندلسي ( ت (أYOه ) والذي يؤلف كتابًا باسم: ( الحلل في

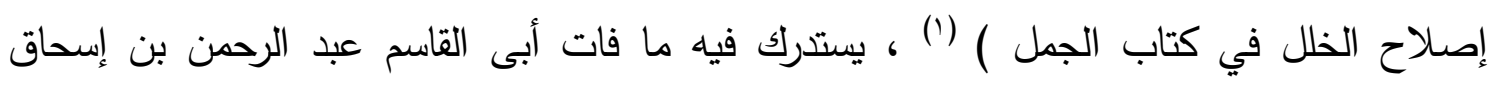

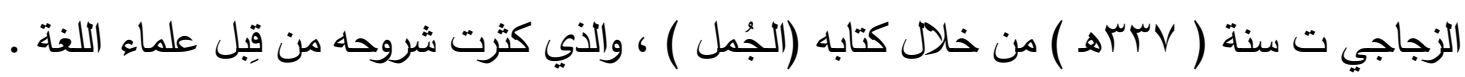
يقول البطليوسي في صدر كتابه : ( وليس اختلال بعض عبارته - يعني كتاب الجمل للزجاجي -

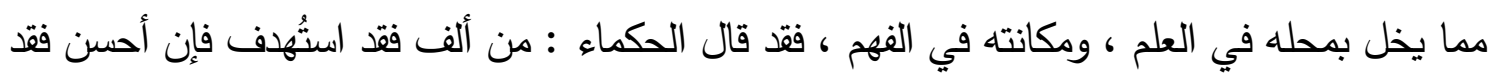

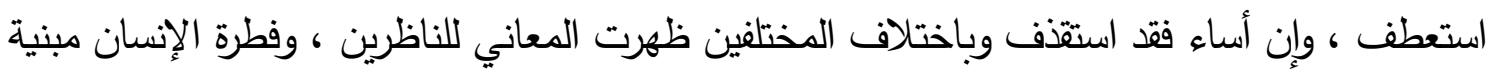

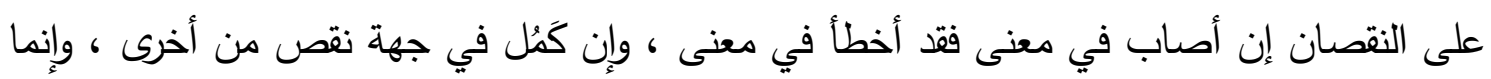

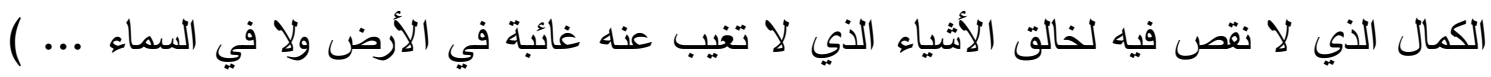

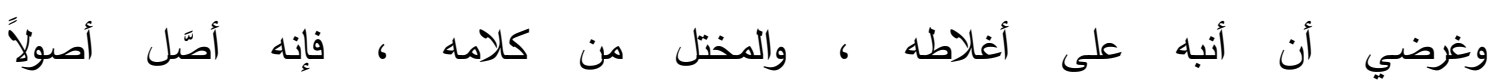

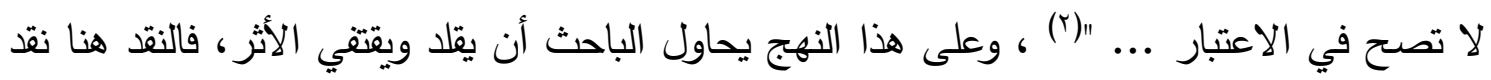

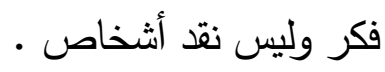

(') كتاب الحلل في إصلاح الخلل في كتاب الجُمل ، لابن السيد البطليوسي ، تح د/ سعيد عبد الكريم سعودي ، بدون

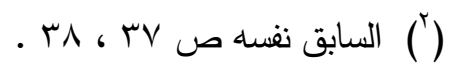




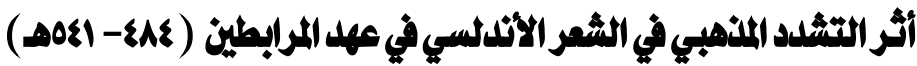

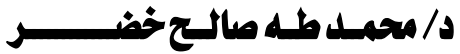

\section{النقـد الفقهـي للتشـد المذهبـي \\ عذ فقهاء المرابطين}

إذا كان البحث يُعنى بناحية النقد الأدبي من خلال الإثارة لضعف الثعر زمن المرابطين ، بسبب التشدد والتحجر الفكري من قِتل فقهاء المالكية . فإن النقد الفقهي قد وقف الموقف نفسه من فقهاء المالكية زمن المرابطين ، وبذا يجتمع الأثباه والنظائر

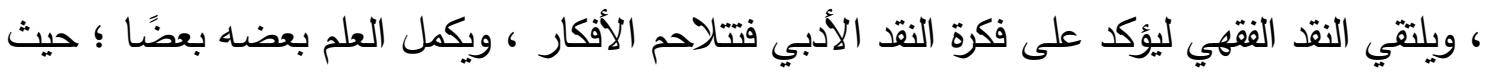

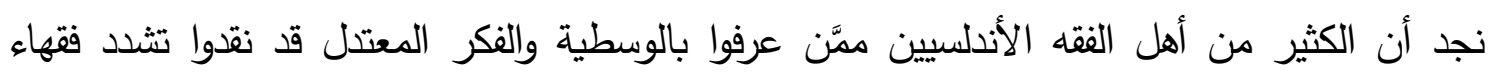

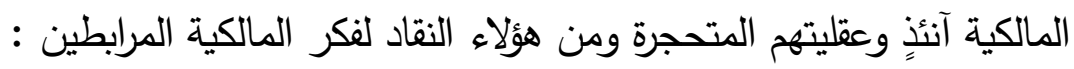

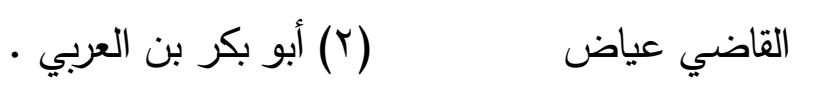

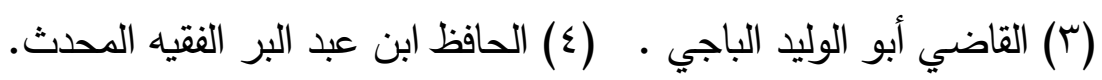

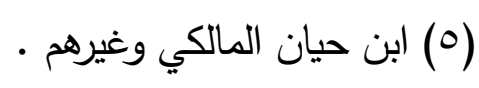

وبعيدًا عن الإطالة في سرد الحوار الجلي بين الرافينين لمنهج التشدد والتحجر عند المالكية ، وبين

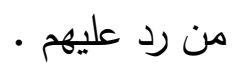
يمكن إيجاز المقصود في الآتي : إنئ ا- ثبت للبحث أن ظهور المذهب المالكي في دولة المرابطين بتحجره وتثدده هذا إنما يرجع إلى

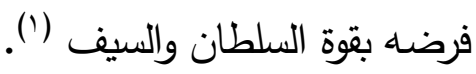

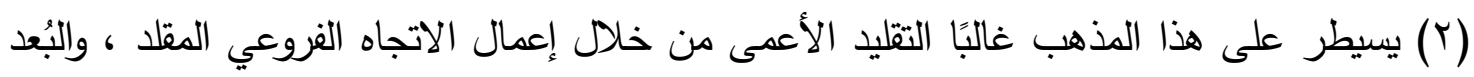

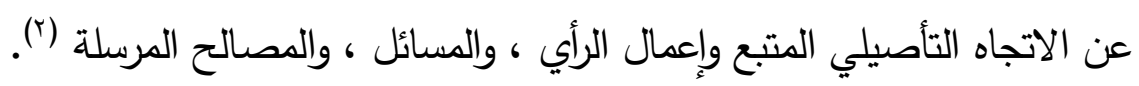

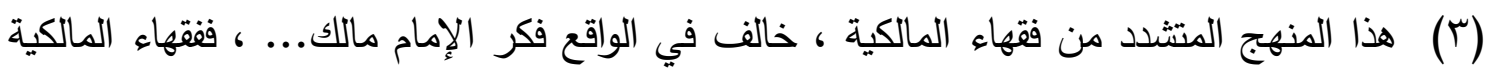

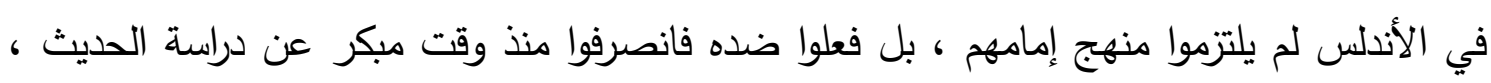

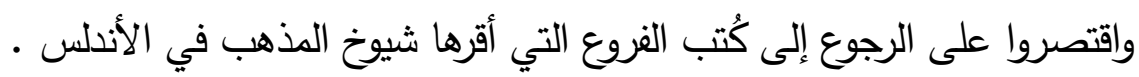

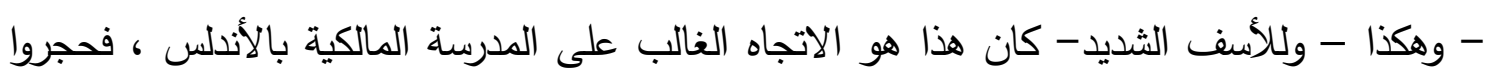

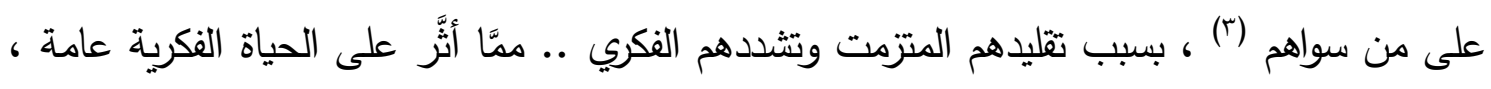
وعلى الإبداع الثعري خاصة فضعف وانحسر ، وأحس الثعراء بالقيد والعجز عن الإبداع .

( (1) للتفصيل والتوسع ، الدرسة المالكية بالأندلس بين التقليد والاتباع ، جامعة الكويت ، مجلة الثريعة والدراسات

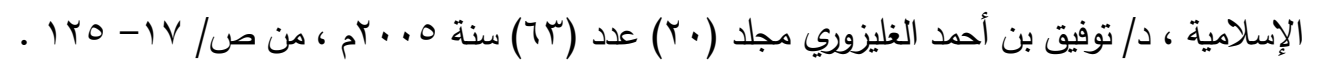

$$
\begin{aligned}
& \text { (') السابق ، ص/ } 97 \text {. } 9 \text {. }
\end{aligned}
$$

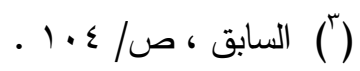


وقد صدق الأستاذ / أحمد أمين في قولهِه عن فقهاء المرابطين بالأندلس : "وقد كان الأندلسيون مقلدين

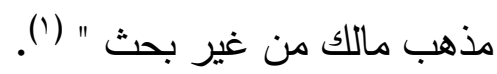

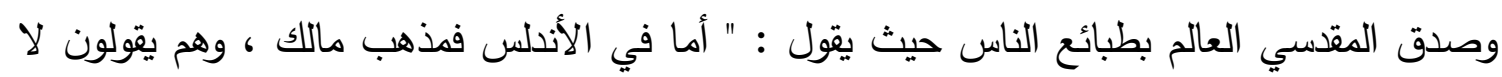
نعرف إلا كتاب الله والموطأ لمالك ، فإن ظهروا على حنفي أو شافعي نفوه ، وإن عثروا على معتزلي الني أو شيعي قتلوه ) (r). وقد انعكس ذلك على الشعر والثعراء . يقول غرسيه غومس : " بدا وكأن الثعر الأندلسي - عهر المرابطين - يلفظ أنفاسه ، كأن كيانه ناء بتقل النازلة ، وانطوى على نفسه إلى حين " (؟).

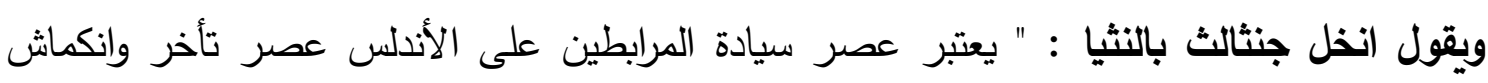

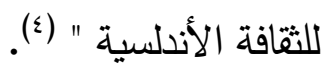

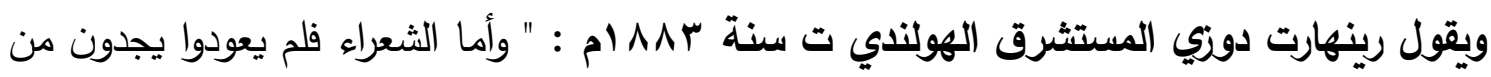

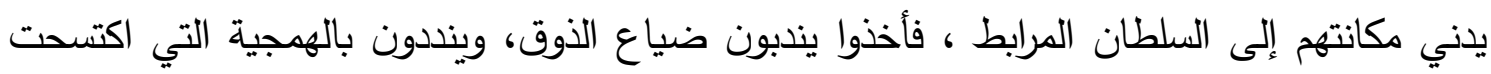

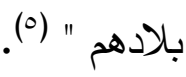
ويقول يوسف أثبا خ المستشرق الألماني ت سنة بA ام : " ولم يبد سلاطين المرابطين كبير عناية

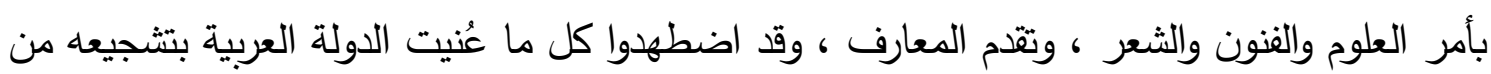

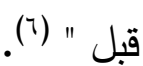

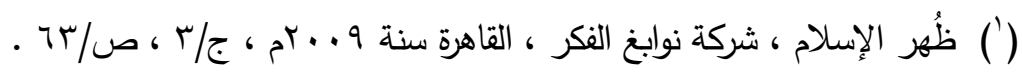

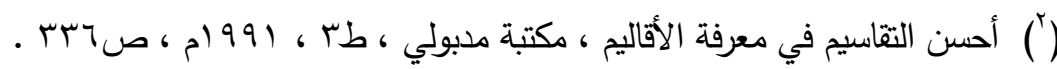

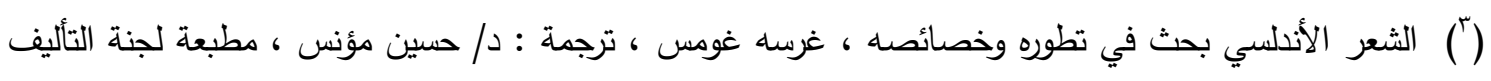

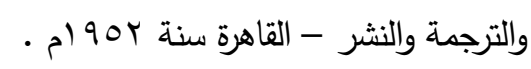

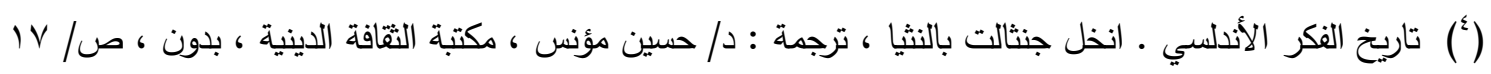

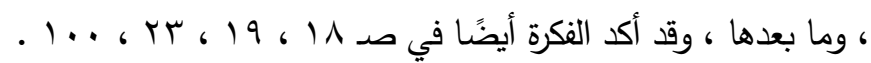

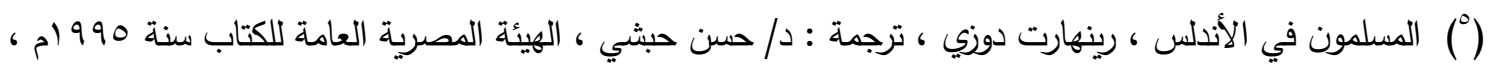

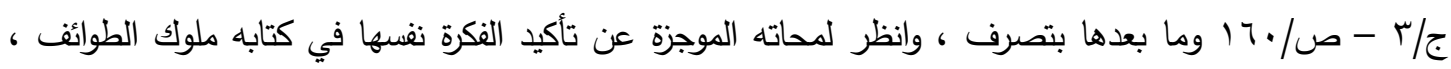

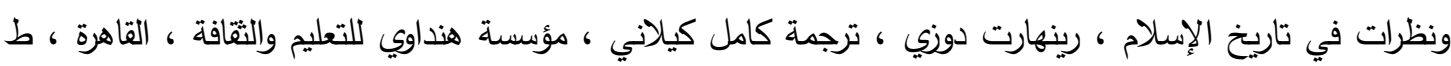

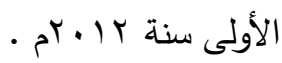

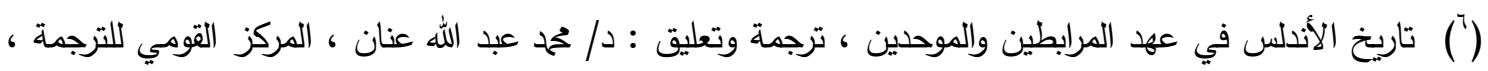

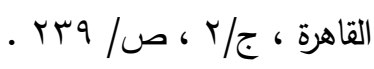




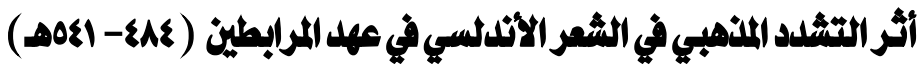

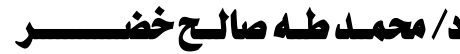

\section{شعراء دولة المرايطين هم بالأصل شعراء دولة الطوائف}

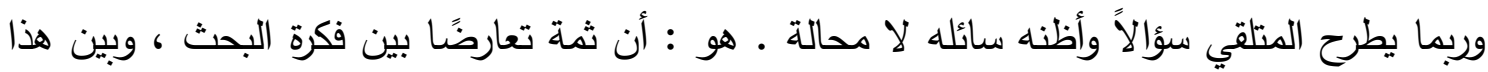

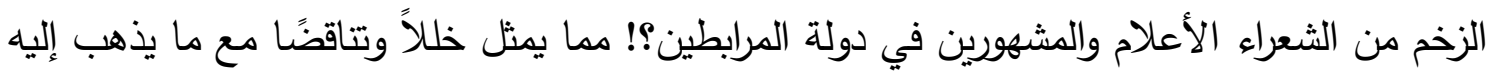

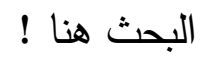

وللإجابة يمكن القول بأن شعراء عصر المرابطين هم بالأصل شعراء عصر الطوائف ممن كوَنوا

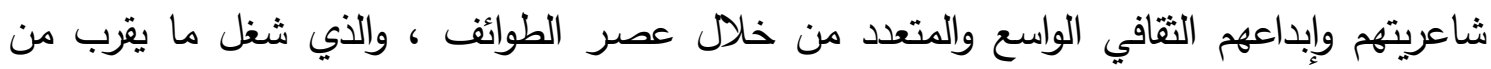

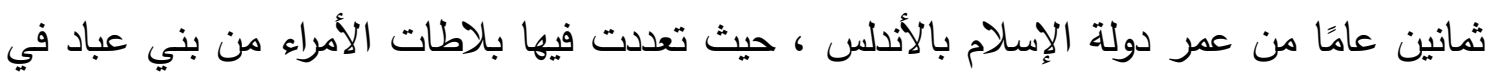

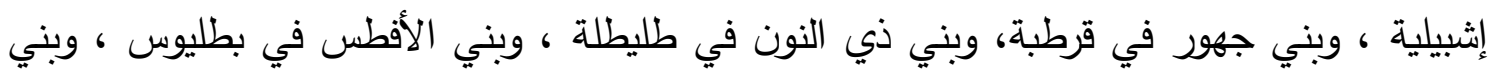
زيري في غرناطة ، وبني هود في سرقسطة ، وبني عامر في بلنسية .

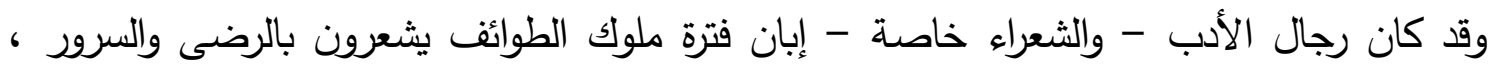

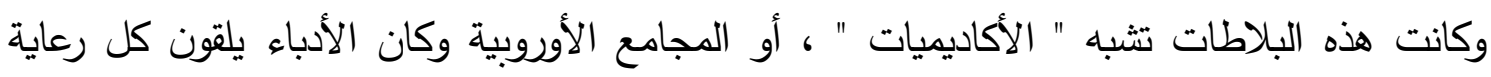
واهتمام ويتلقون من الأهراء مرتبات شهرية (')

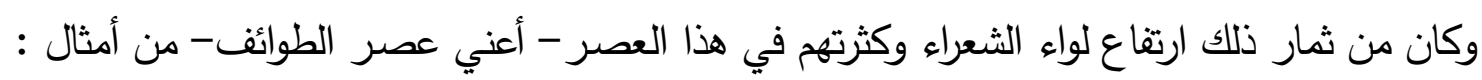

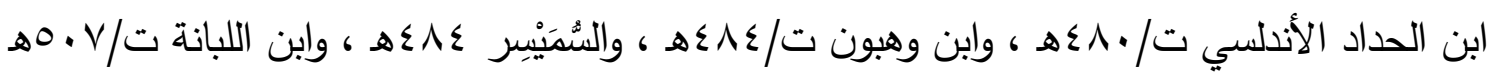

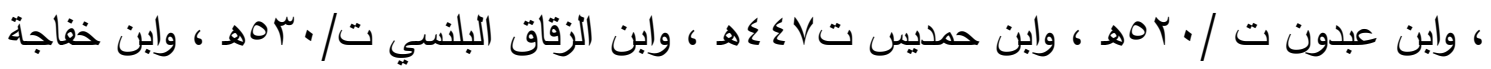

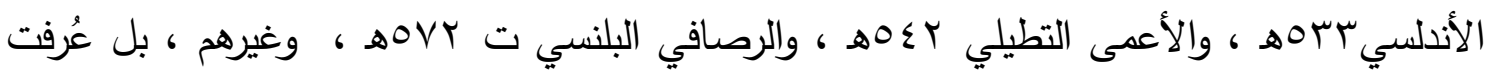

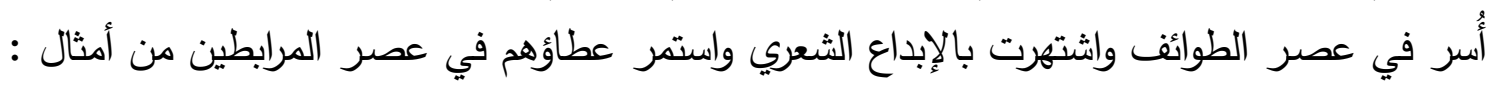

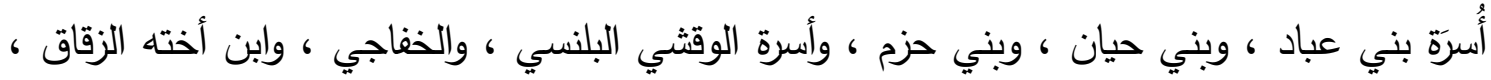

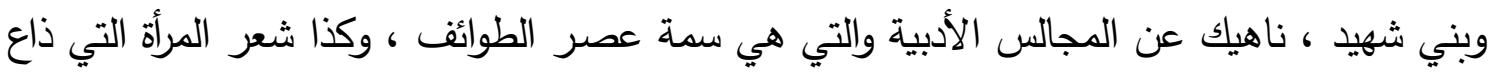

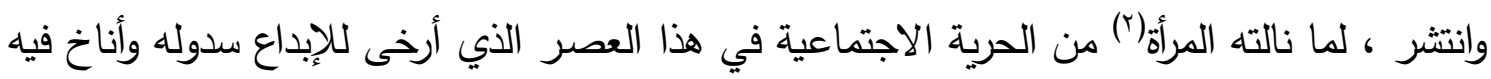

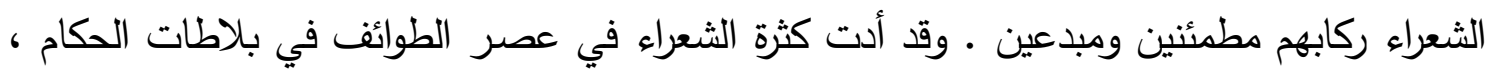

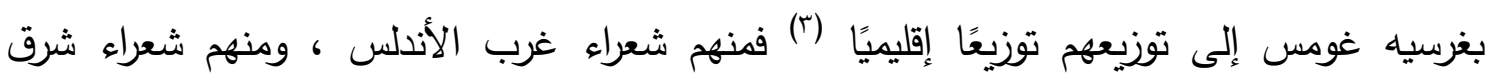

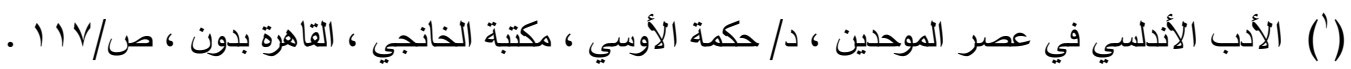

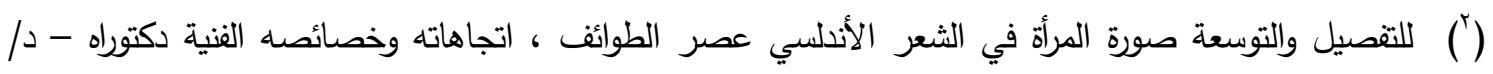

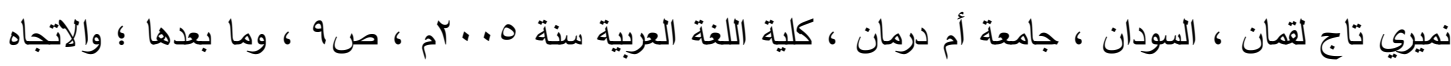

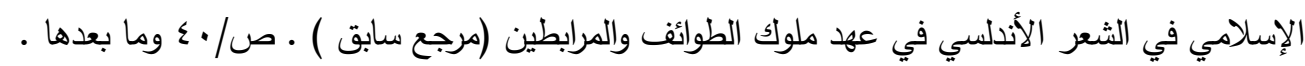

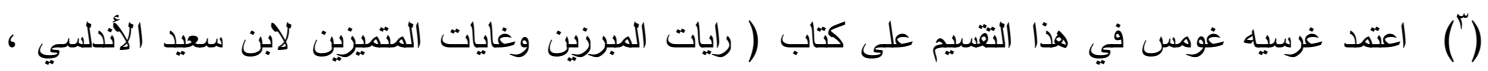

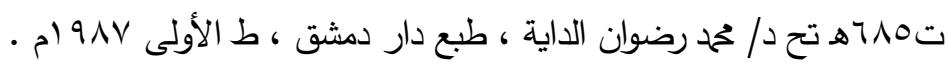


الأندلس، ومنهم شعراء وسط الأندلس ('). يقول غومس في حديثه المنصف عن عصر الطوائف : وكان هذا الزمان عصرًا عظيمًا للشعر والثعراء ، إذ تنافس ملوك الطوائف في اجتذاب الثعراء إلى لى

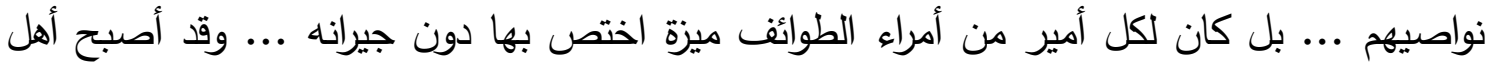

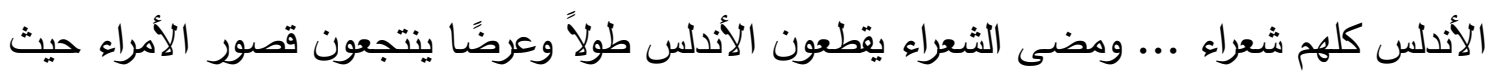

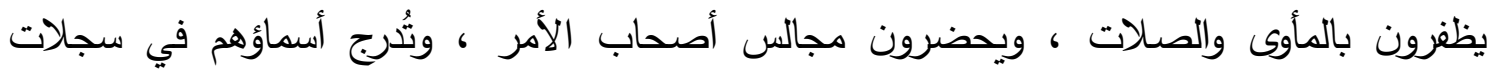

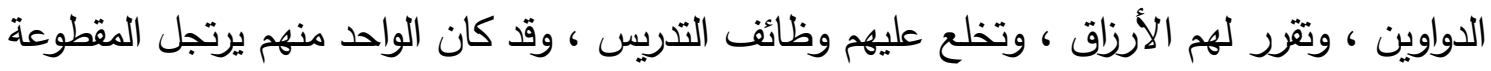

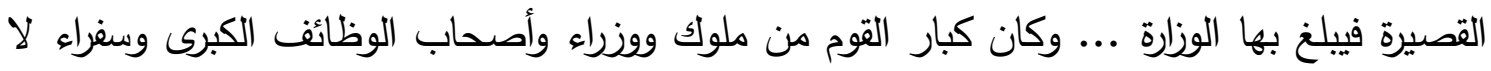

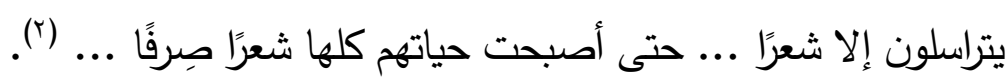

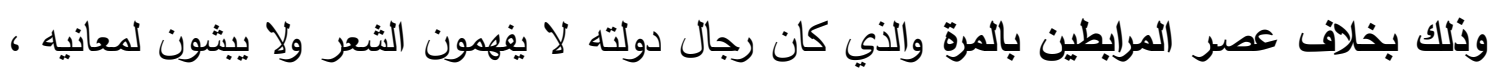
للموقف المتثدد من فقهاء المالكية أصحاب السطوة والحل والعقد الأمر الذي سيكون له تداعياته السلبية . وعليه فإن القارئ المُلم بحيوات الشعراء في عصر المرابطين ليجدهم بالإجماع هم من شعراء دولة

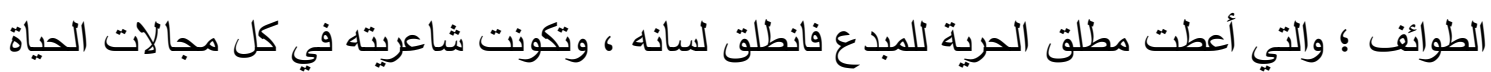
، لأن الثعر إلهام وإبداع ينهض وينثط في جوار السلطة التي تفهمه وتقدره .

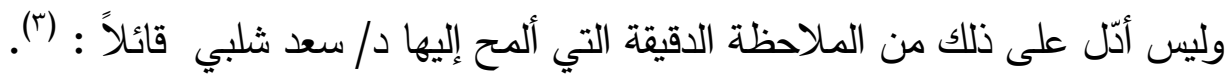

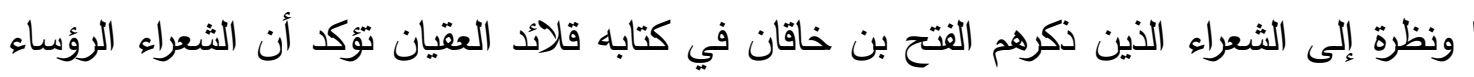

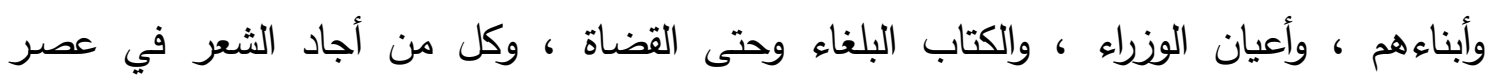

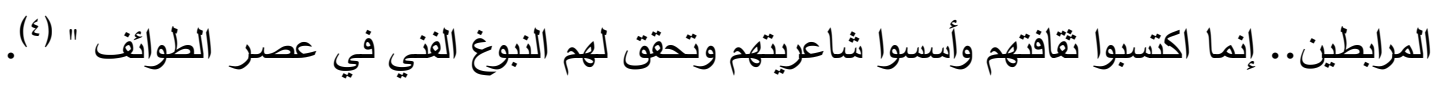
والملاحظة النقدية الثانية هنا والجديرة بالذكر : أن معظم الثعراء المشهورين ، والذين نالوا حظوة أيام عهد المرابطين - هم من الكُتَّاب الذين أجادوا

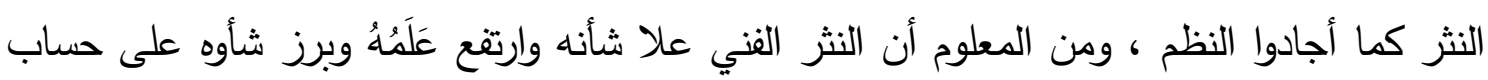

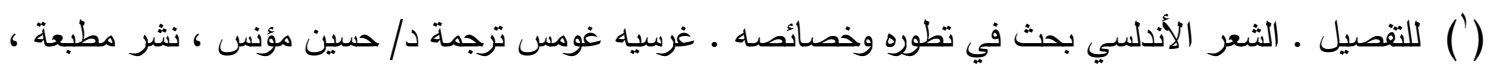

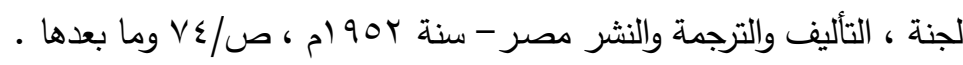

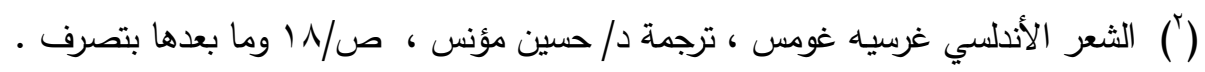

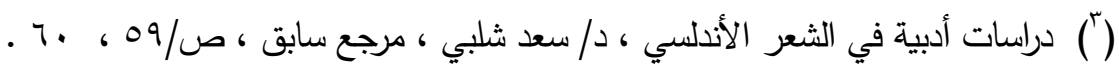

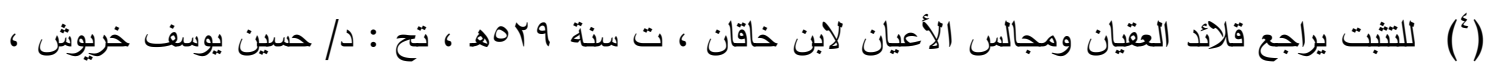

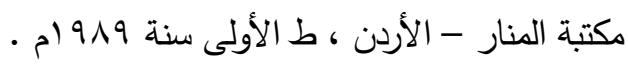




\section{د/ محمـلد طـه صالـحخض}

الثعر في عهد المرابطين ، لأنها دولة الحروب والقتال ، ودولة الفقهاء ، ومن ثم كان النثر الفني هو

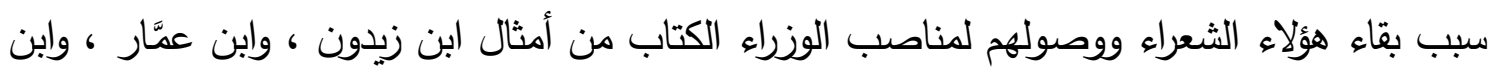

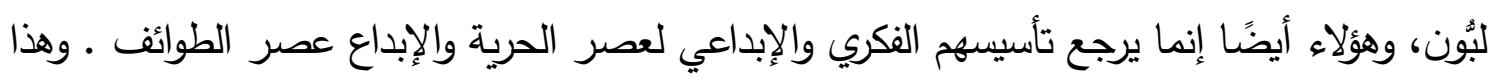
هو ما قصده صاحب قلائد العقيان في ترجمته لهم تحت عنوان : (محاسن الوزراء والقضاة

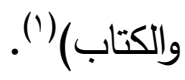

والواقع أن الأدب الأندلسي يؤكد اهتمام المرابطين بالنثر الفني (؟) عامة ، والكتابة الفنية خاصة ،

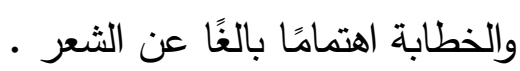

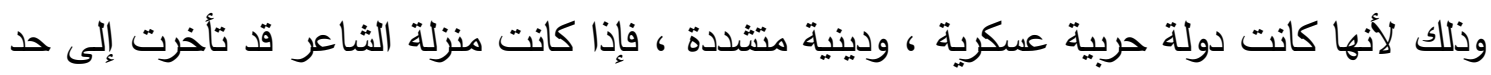

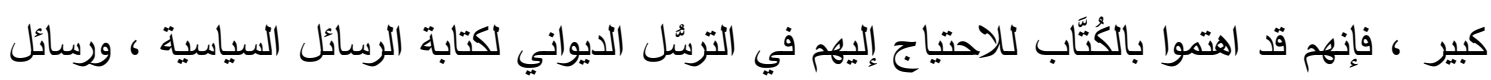

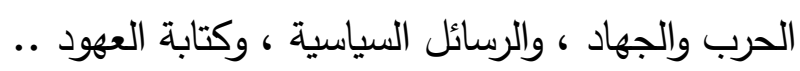

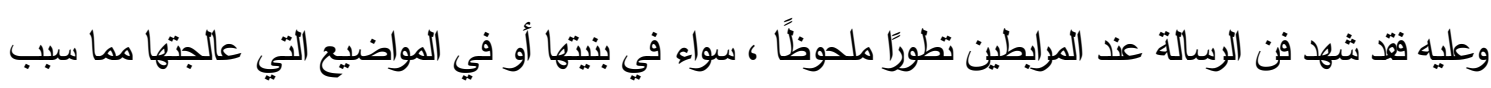

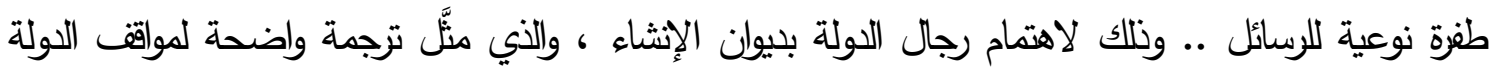
السياسية والقانونية والأخلافية ... ولذا فهي منبر الحكم في البلاد ، ومزسوم الحاكم إلى المحكوم (").

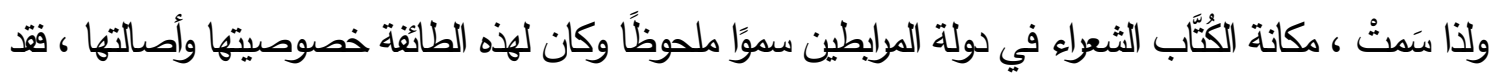

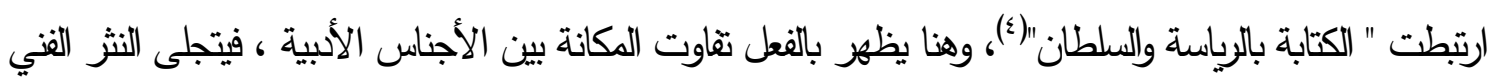

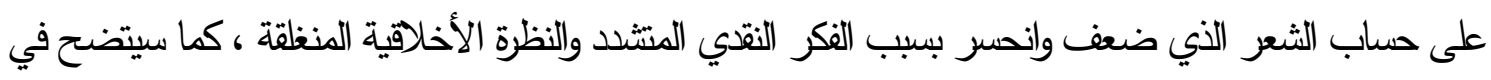
المعالجة لوأي الكلاعي في تضضيله النثز على الثعر واتهامه له ، والحطمن شأنه في كتابه ( إحكام صنعة الكلام)

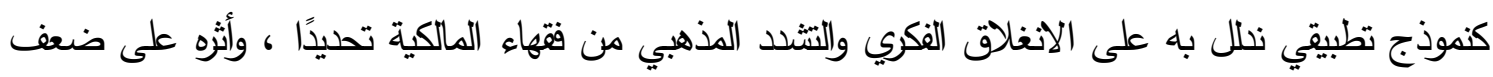
الثعر ، والتضييق على الثعراء في عهز المرابطين .

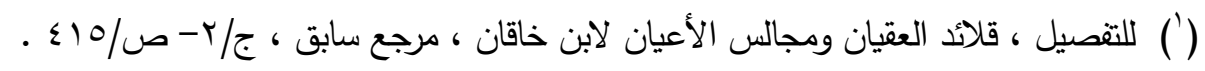

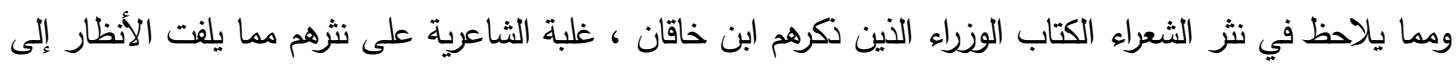

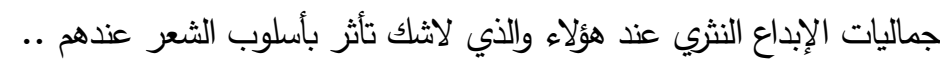

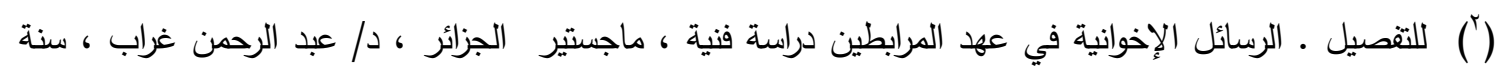

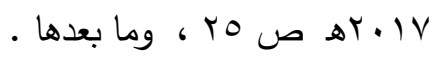

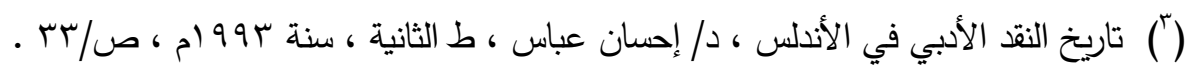

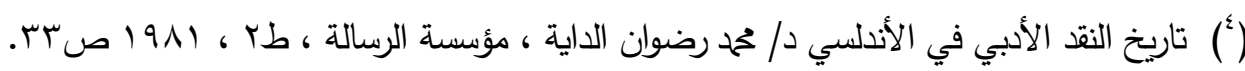




\section{المبحث الأول}

الكلاعي وكتابه( إحكام صنعة الكلام ) نمونجًا تطبيقيًا للتثدد الفقهي في عهر المرايطين

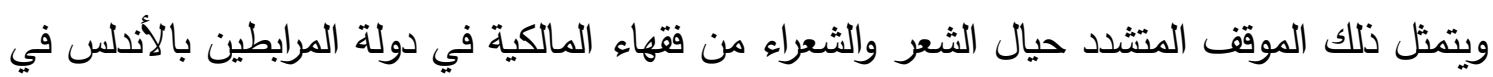
( كتاب إحكام صنعة الكلام) لابن عبد الغفور الكلاعي (')

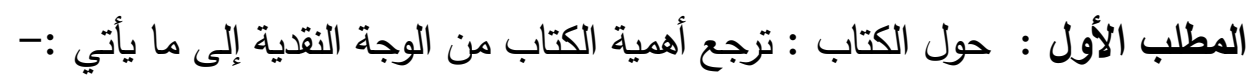

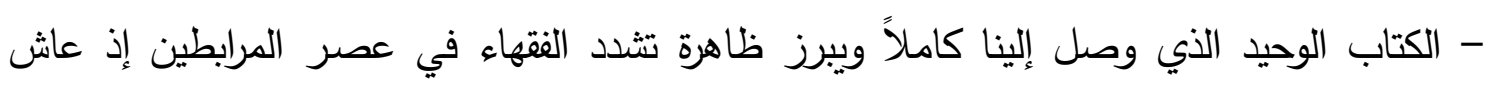
الرجل في زمن المرابطين وفي بلاطهم •

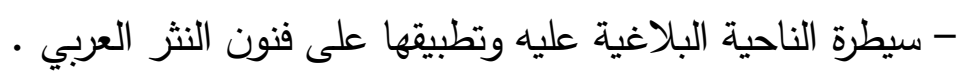

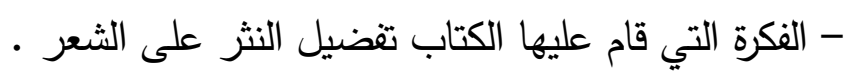

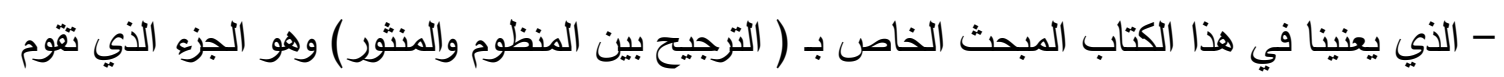

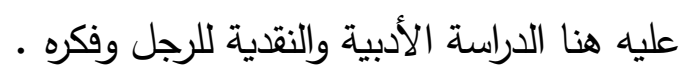

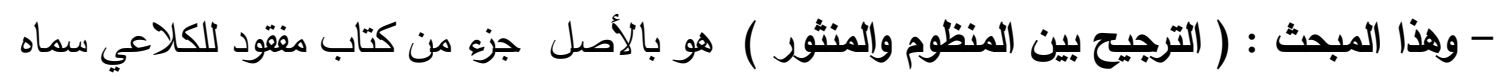

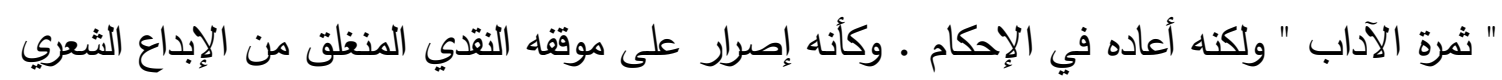
على امتداد مسيرة الرجل الفكرية والتأليفية .

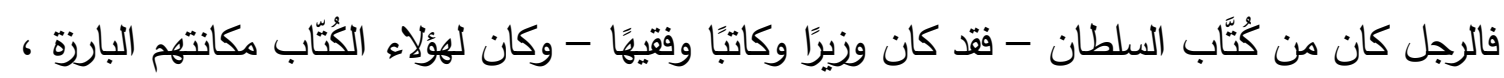

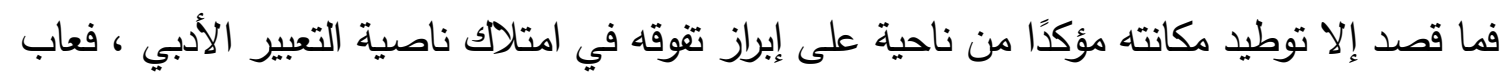

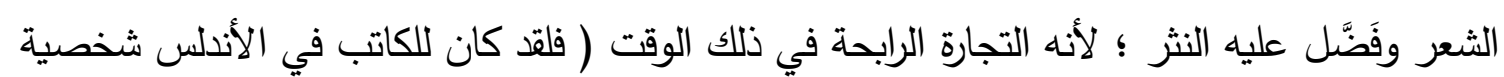

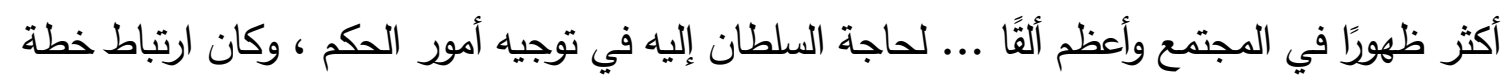

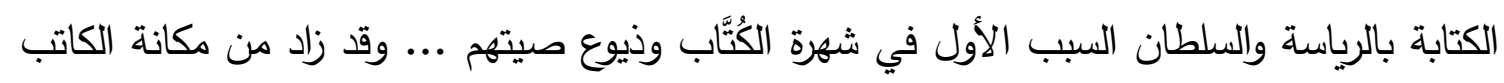

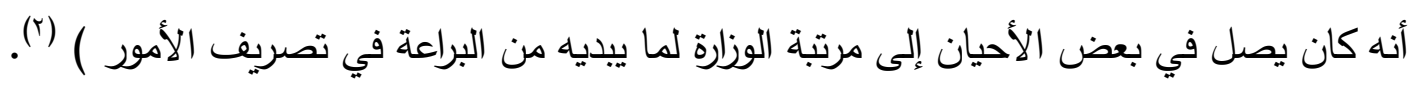

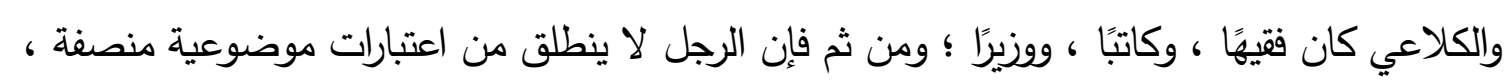

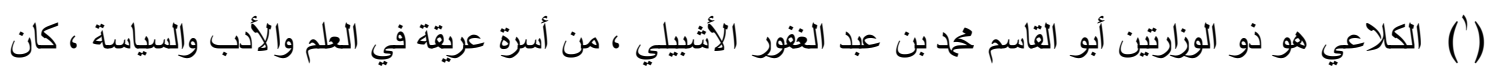

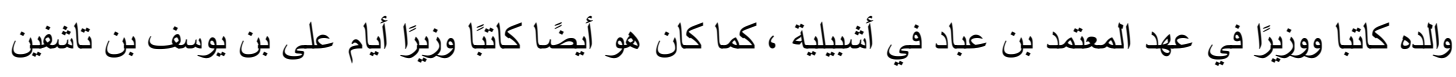

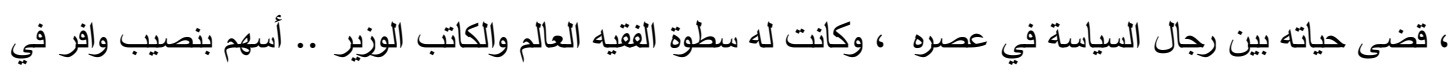

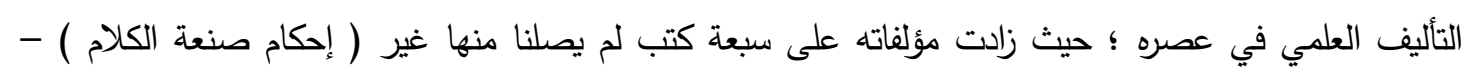

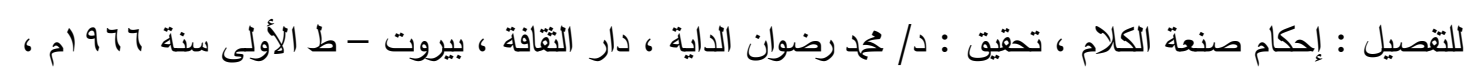

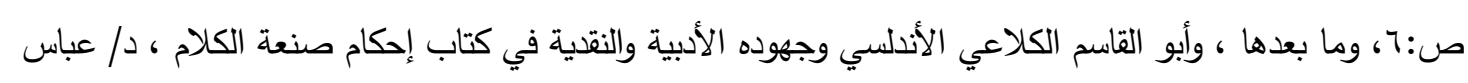

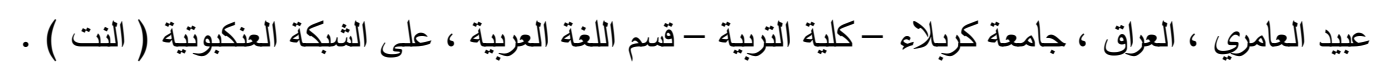

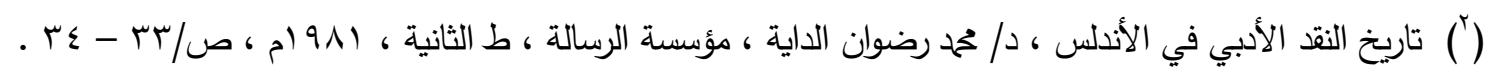




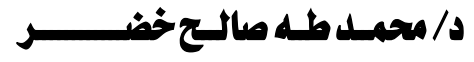

وإنما من اعتبار ذاتي نفعي في المقام الأول الأمر الذي يؤكد ( أن الثقافة المسيطرة هي ثقافة الفقهاء ،

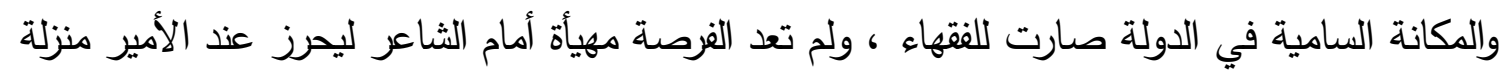

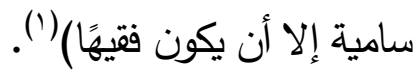
وهنا يتغلب الفقهي على الأدبي ، ويظهر سبب من أسباب انغلاق فقهاء المالكية، ورفضهم للآخر في

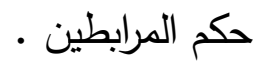

- يسيطر على الكتاب طريقة الفقهاء في كثرة التقسيمات والمصطلحات التي وضعها الرجل .

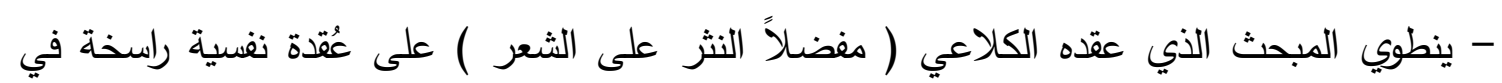

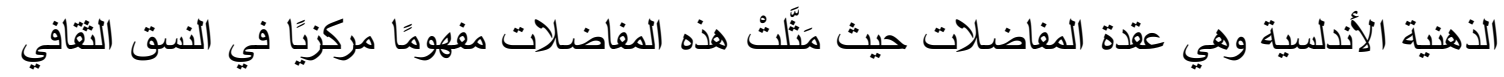

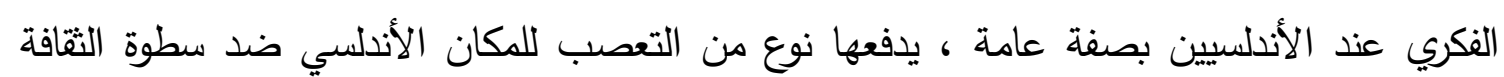

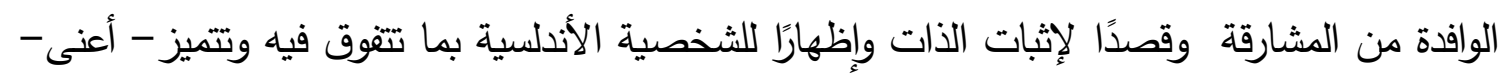

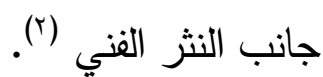
يستهل الكُلاعي نقده قائلاً بأن ما يطرحه هو من باب "المستطرف والمستغرب" (")، ومن ثم نجده

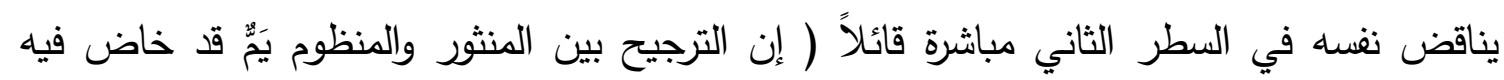
الخائضون ، وميدان ركض فيه الراكضون ) (5). ومن المعلوم أن الدفاضلة بين المنظوم والهنثور سبق إليه الأدباء والعلماء من قبله سواء من المشارقة أو الأندلسيين (o) ولعلنا نلمح الغمز واللمز الخفي في قوله : " والترجيح بين المنظوم والمنثثر يٌَّ قد خاض فيه

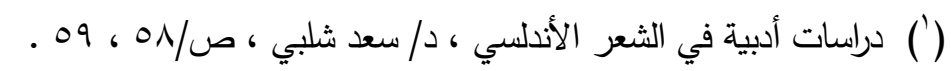

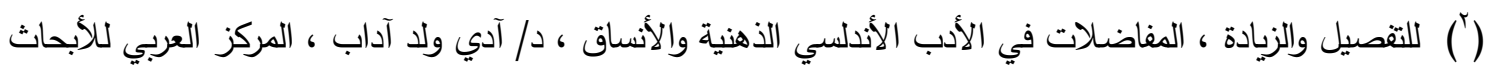

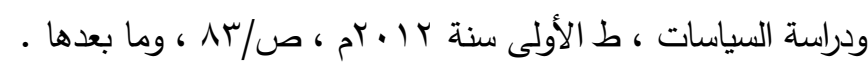

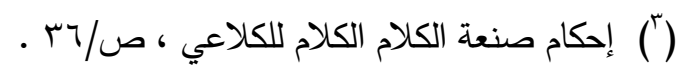

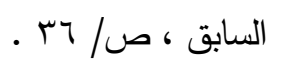

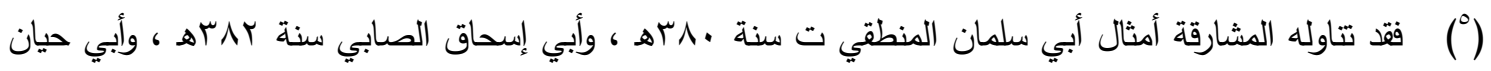

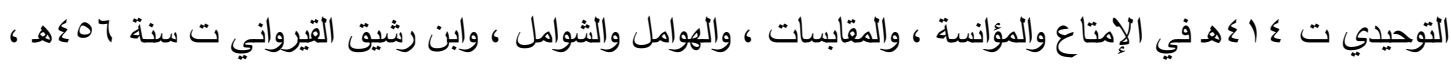

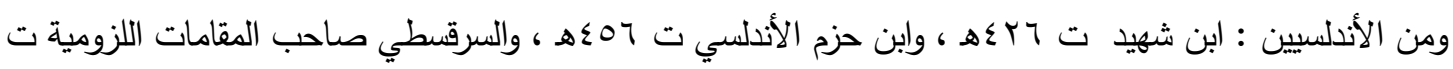

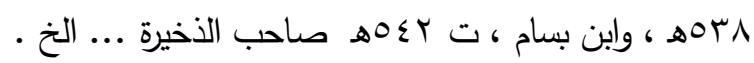

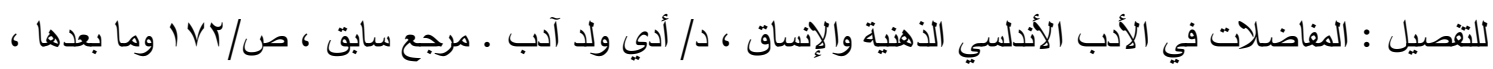

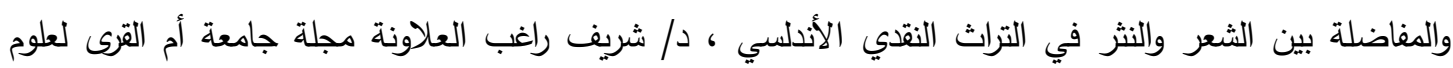

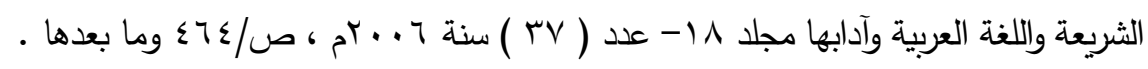


الخائضون " والمعلوم أن الخوض لا يكون إلا في الباطل أو الانغماس فيما فيه فساد ـ قال الله تعالى :

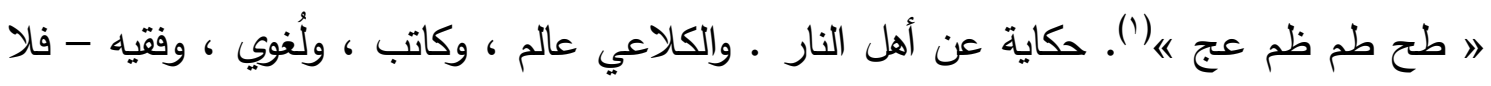

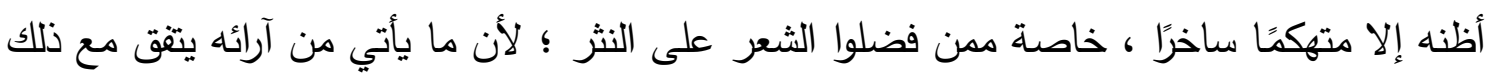

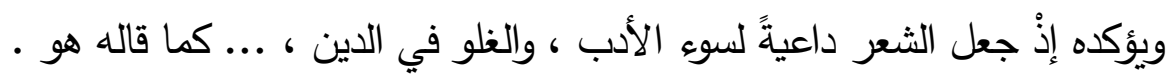

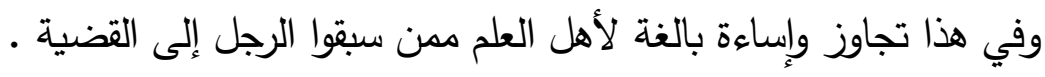

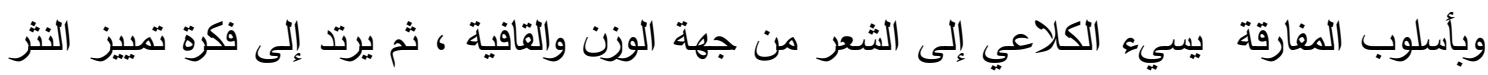

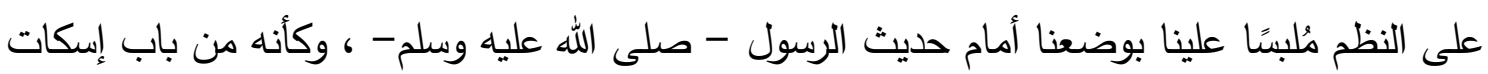

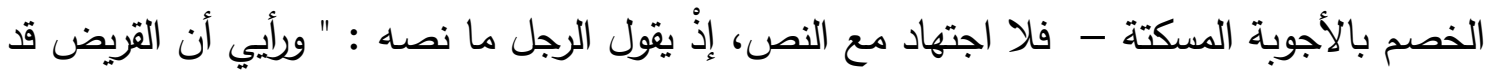

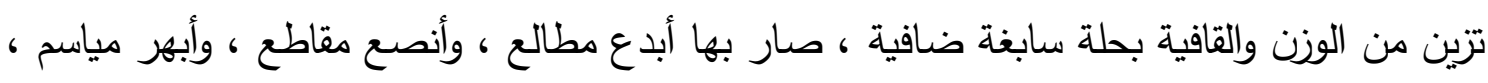

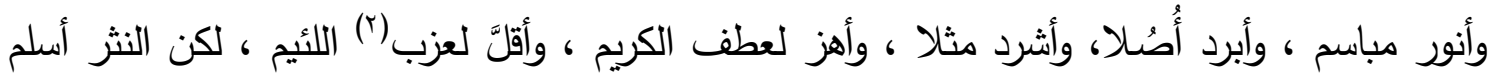

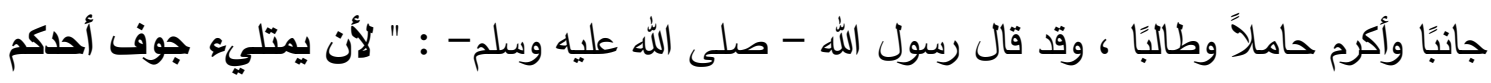

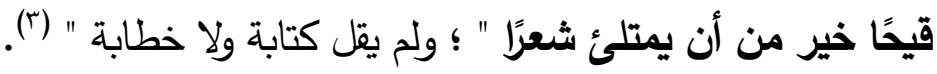
يظهر تتاقض الكلاعي مع نفسه في جعله الوزن والقافية هي محاسن الثعر وميزته من خلال تكراره

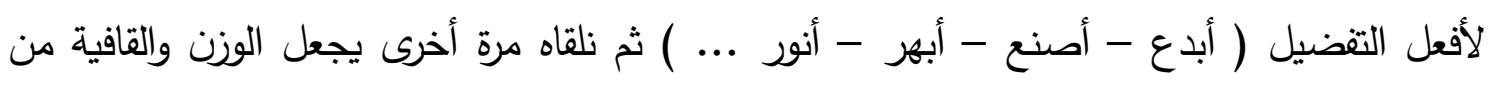
معايب الثعر ومقابحه إذ يقول : "ومن معايب الثعر ما فيه من الوزن ، لأن الوزن داع للترنم ، والترنم

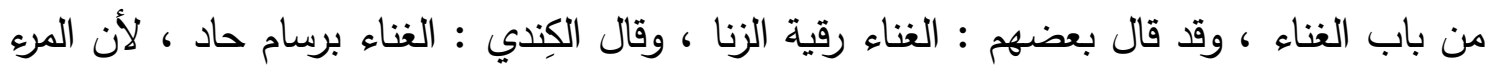

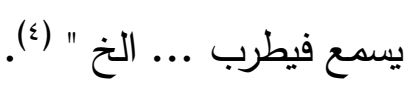

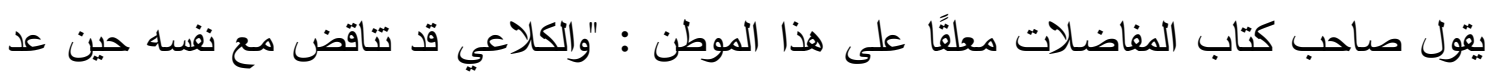

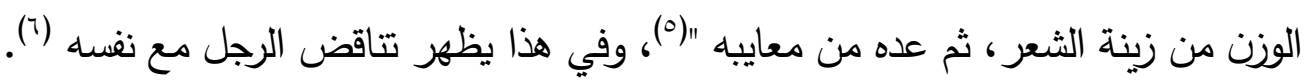
وأما استثهاده بالنص النبوي الثريف ليعيب الثعر ، ففيه ردود :

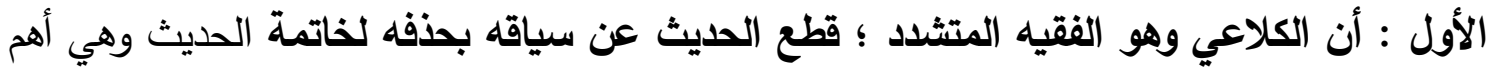

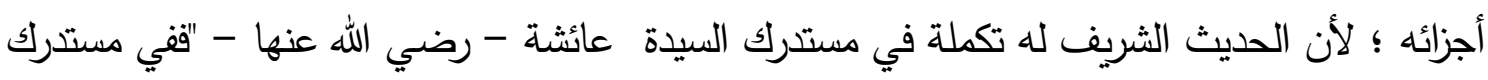

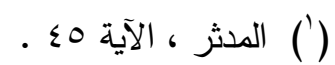

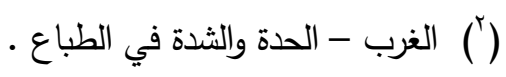

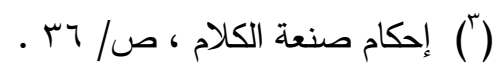

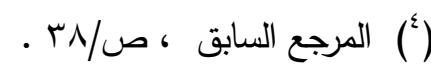

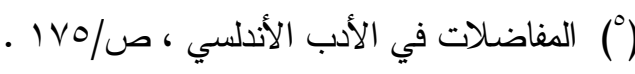

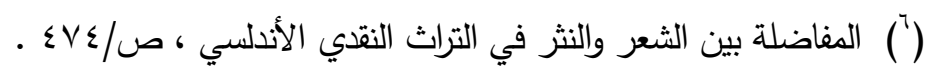




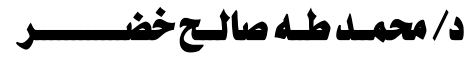

الزركثي - أن عائثة - رضي الله عنها - قالت مستدركة على أبي هريرة لم يحفظ الحديث " إنما قال

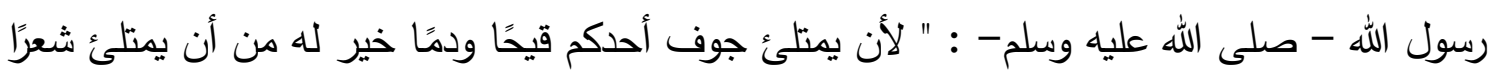

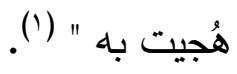

الثاني : - مما يؤخذ على فقهاء المالكية في الأندلس إبان حكم المرابطين تثددهم وانغلاقهم الفكري

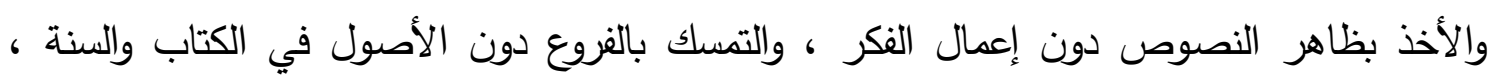

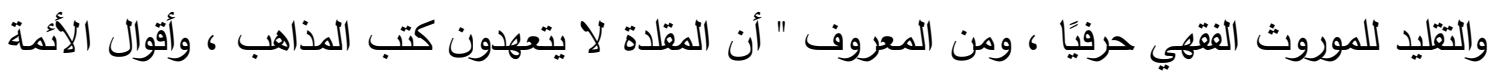

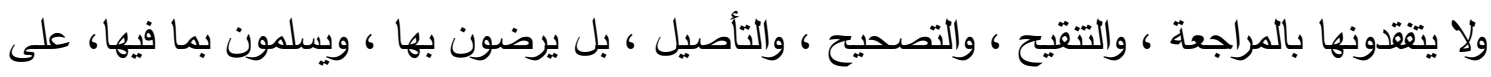

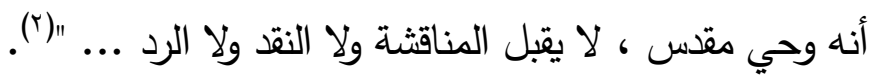
وبلغ من تثددهم تحريم علم الكلام والفلسفة ، وإحراق كتبها ؛ - مثلما فعلوا مع كتب أبي حامد الغزالي ، وذلك دليل على الجمود الفكري ، ومحاربة الاجتهاد ، والتجديد ومعاداة التيارات العقلانية وأنصارها ،

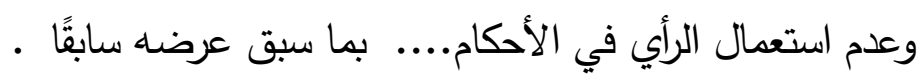
وعلى هذا النهج ينطلق الكلاعي في حكمه على الثعر والإقلال من شأنه بما يتقق وهذه العقلية المتحجرة ، فلا اجتهاد مع النص ، والحديث السابق على ظن الكلاعي يُغلق القضية ويسكت الأفواه ،

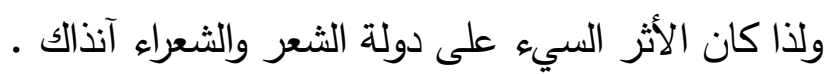
وقد لقي المنهج المتثدد من مالكية المرابطين رفضًا واسع المدى عند كثير أهل العلم في الأندلس من

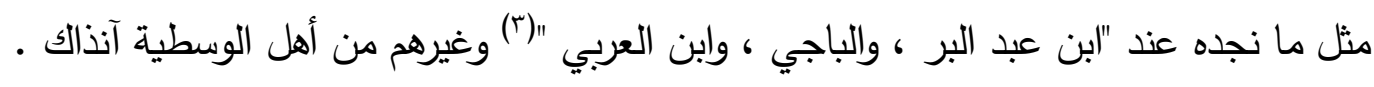

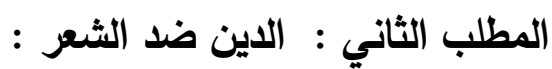

والقارئ لكتاب الإحكام يرى أن الكلاعي تسيطر عليه النزعة الضيقة والمتثددة ، والتي تميل إلى القول

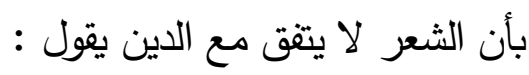
" فالثعر داع لسوء الأدب ، وفساد المنقلب ؛ لأنه لضيقه وصعوبة طريقه - يحمل الثاعر على الغلو

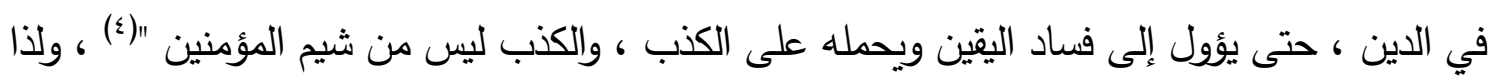

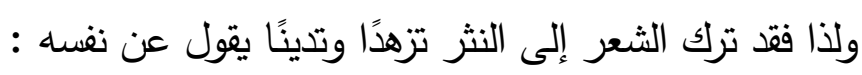

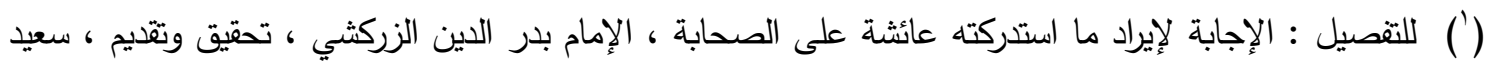

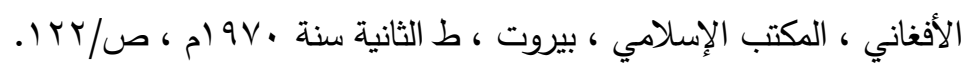

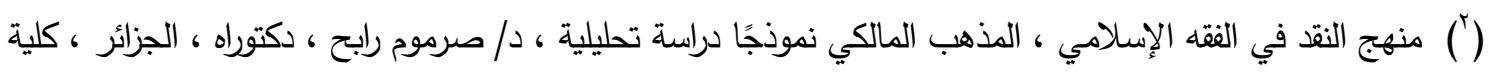

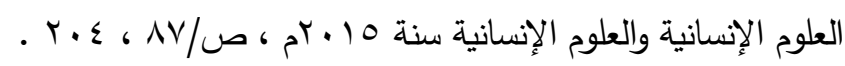

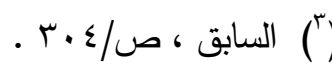

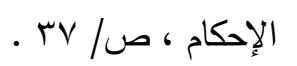


" فنزعت منزعًا كريمًا من علم الديانة ، واقتصرت من قسمي البلاغة على قسم الكتابة ، لأنها أنجح عاملاً، وأرجح حاملاً " ('). ويقول : " وقد نزهت طائفة من العلماء اسم الله تعالى عن الاستفتاح به فكتبوا في أول قصائدهم بذكر

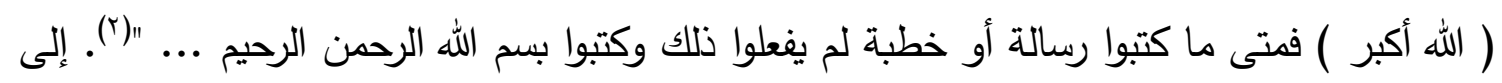

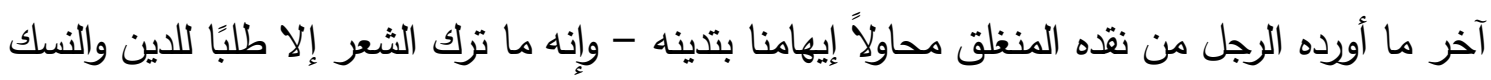

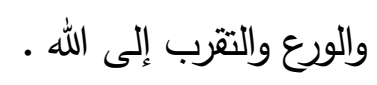

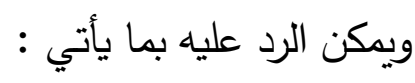
1- أن الكلاعي نفسه كان شاعرًا يجيد الشعر وهو القائل عن نفسه = " وقد كُنت مُولعًا بترصيعه وتصنيعه مائلاً في تقريطه وتشنيفه إلى رتبة كنت أعدها أعلى المراتب، ومنقبة كنت أعتقدها أسمى لفئ

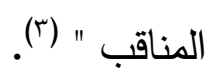
وقد ترك الثعر إلى النثر يقول : " إلى أن رفضته رفض الثعلة للزناد ، ونفضته نفضًا القادم الغانم

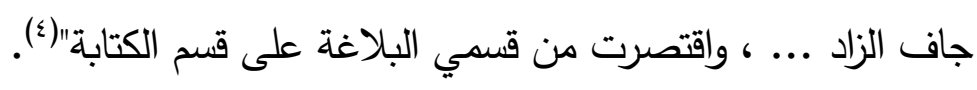
r- إن الكلاعي ما ترك الثعر برضاً وقناعة فكرية من تلقاء نفسه ، ولكنه تركه مرغمًا لأجل مسايرة

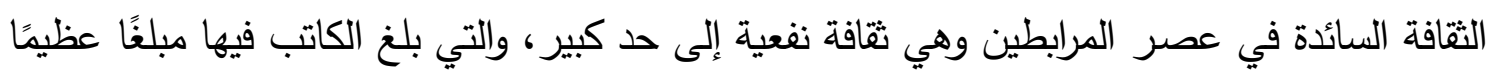

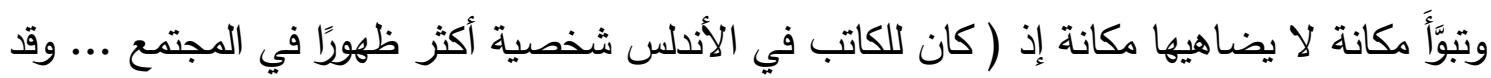

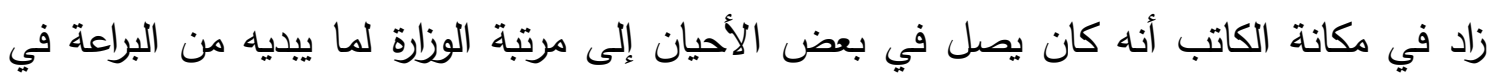

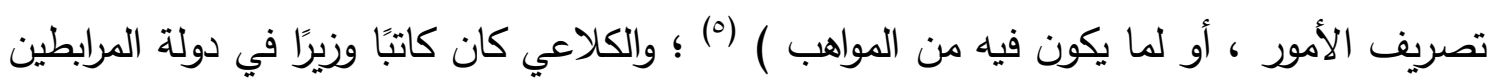

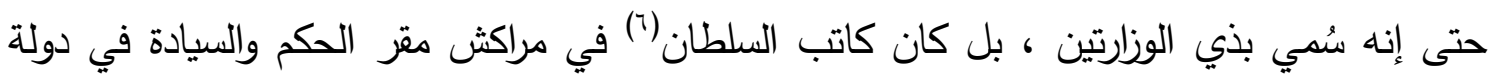

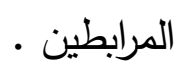
إضافة إلى " كون المكانة السامية في الدولة صارت للفتهاء ولم تعد للشعراء فالثقافة المسيطرة هي

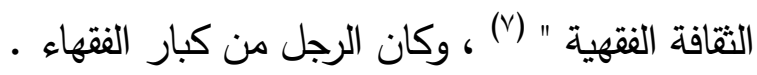

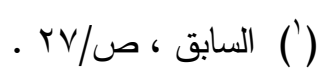

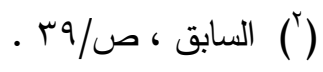

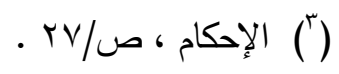

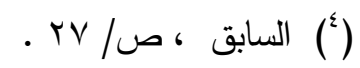

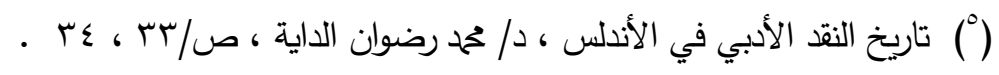

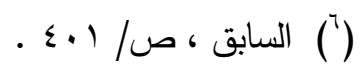

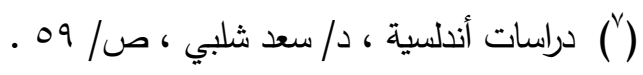


المطلب الثالث : " التكسب بالمديح ·

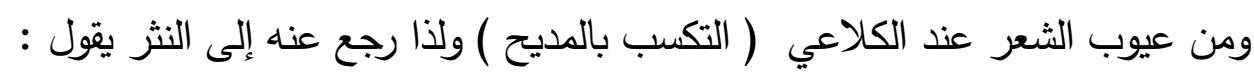

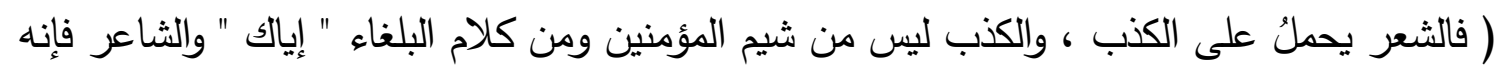

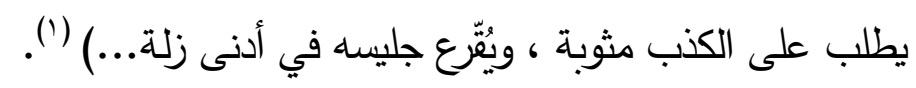

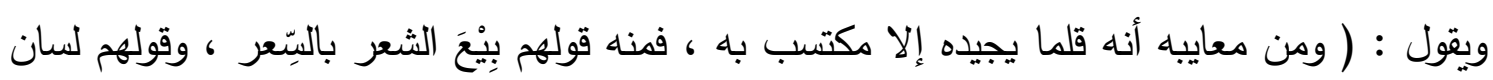

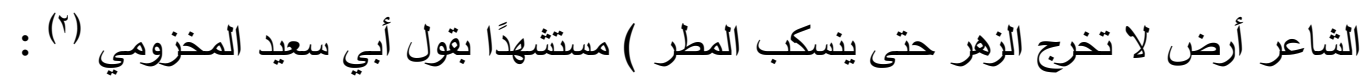
الكلب والثاعر في حالة يا ليت أنتي لم أكن شاعرًا

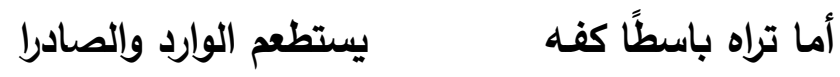

ويمكن نقد ذلك بما يأتي : تمائ تتاقض الرجل مع نفسه بداية إذ جعل التكسب من معايب الثعر وفي الوقت نفسه يقر بأنه دافع من

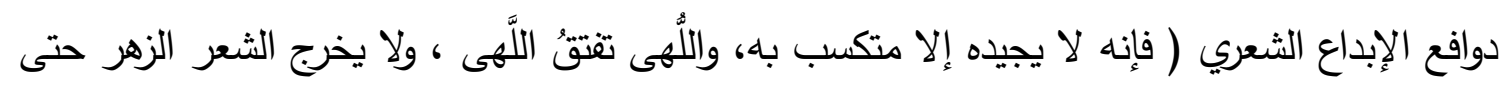

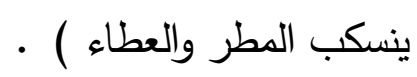

- فكيف يُعد التكسب أو العطاء على الثعر عيبًا ، وهو إحدى دوافع الإبداع والقوة المحركة له ، يقول

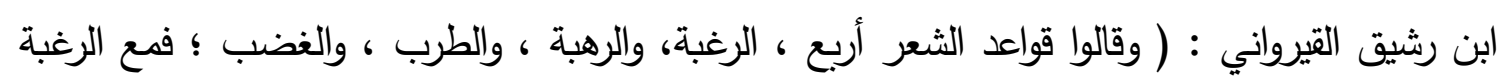

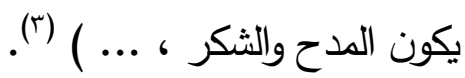
وهذا ابن رشيق يضرب لنا مثلاً ( بأرطاة بن سهية عندما قال له عبد الملك بن مروان : أتقول الشعر

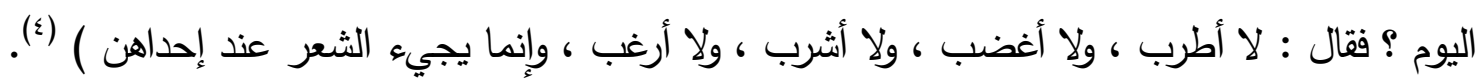

ويعلل الثاعر الخريمي جودة مدائحه بهذه الدافعية قائلاً : " كنا مع الدديح نعمل على الرجاء ، ومع الرعاء

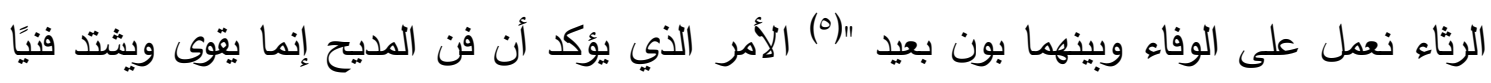

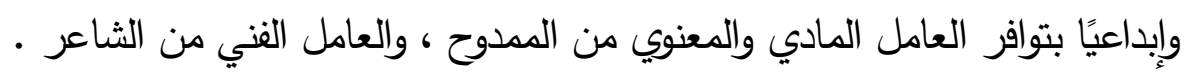

$$
\begin{aligned}
& \text { (') الإحكام ، ص/ (') }
\end{aligned}
$$

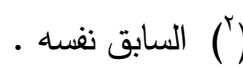

(") العدة في محاسن الثعر ، لابن رشيق ، تح : محمد محيي الدين عبد الحميد ، دار الجيل - ط الخامسة -

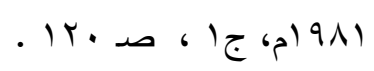

(أ) العدة في محاسن الثعر ، لابن رشيق ، تح : جحم محيي الدين عبد الحميد ، دار الجيل - ط الخامسة -

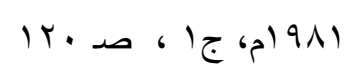

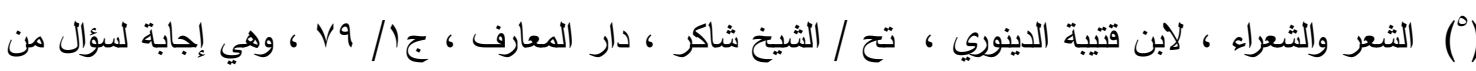

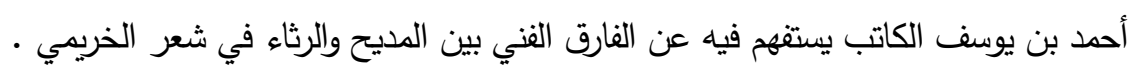


ז- إن هذا التشدد لم نألفه حتى في زمن الرسول - صلى الله عليه وسلم- ومع صحابته ، فلم نقرأ أن

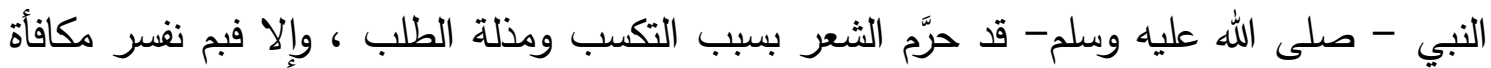

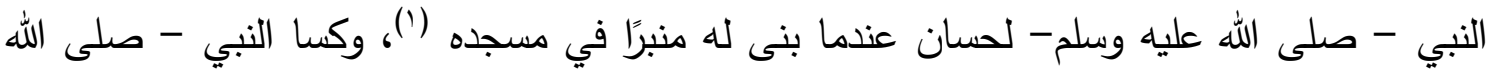

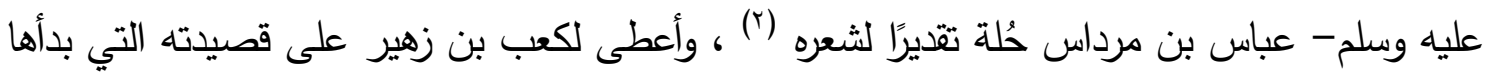

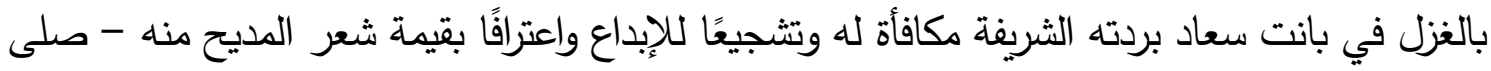
الله عليه وسلم- وحتى عمر بن عبد العزيز الخليفة الراشد سمع الثعر ، وأجاز الثعراء عليه وأعطاهم

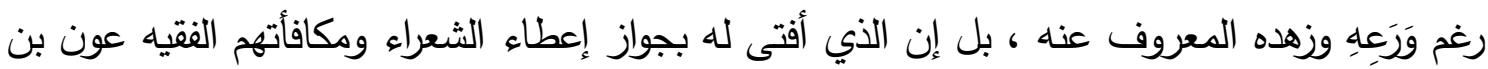
عبد الله بن عتبة بن مسعود - رضي الله عنه - وأرضاه (r).

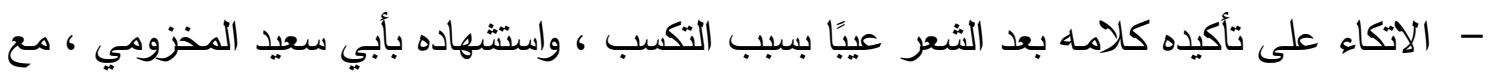

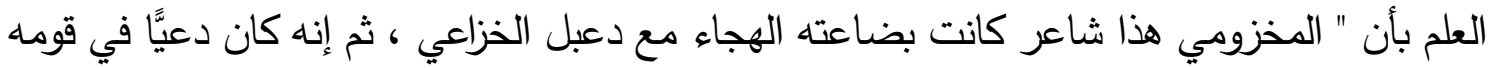

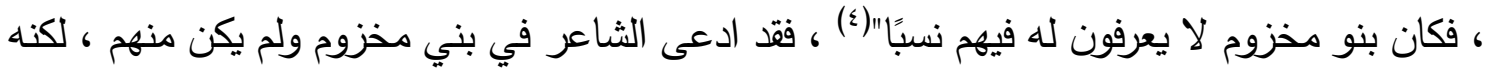

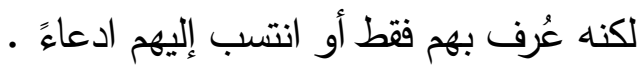

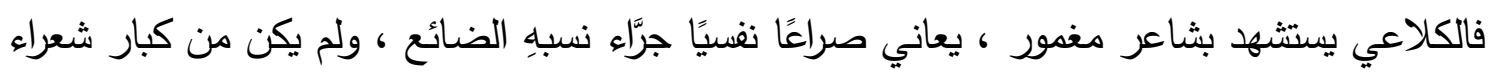

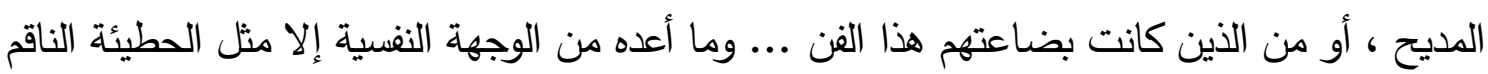

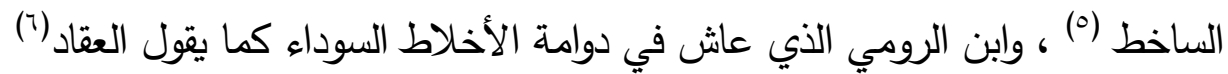

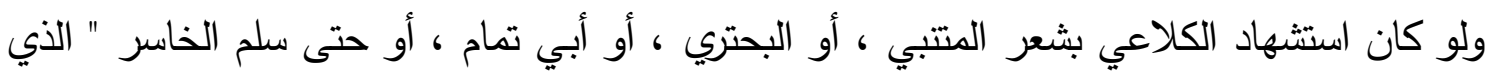

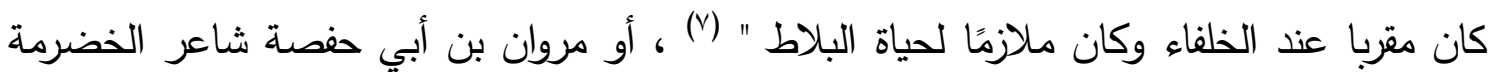

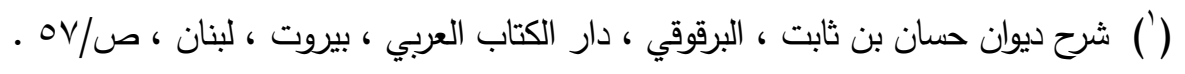

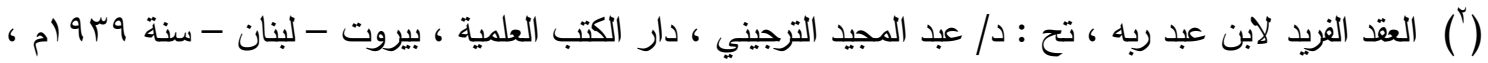

$$
\text { . rTr / }
$$

(") اللتصيل : الخليفة عمر بن عبد العزيز والثعر ، طا عبد الحميد المعيني ، طبع ونشر نادي أبها الثقافي ، ط

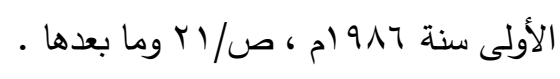

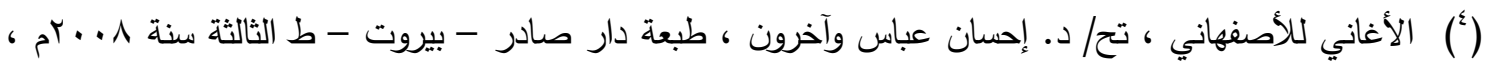

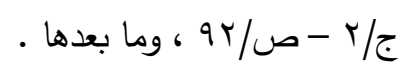

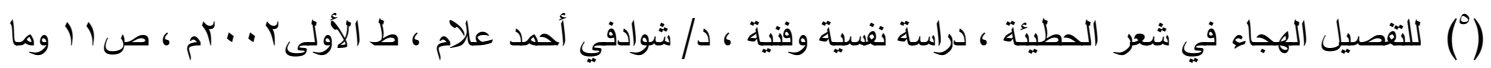

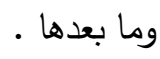

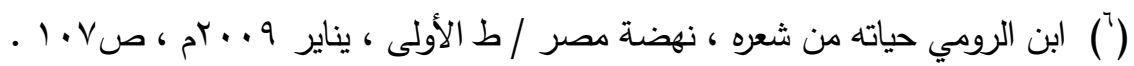

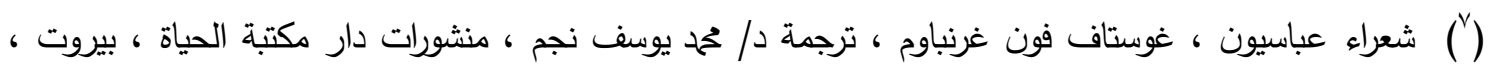




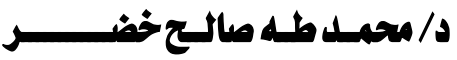

الدتلون ، أو أي أحد من شعراء هذا الفن - أعني فن المديح - لوقع الحافر على الحافر وأصاب المقصد .

وذلك لأن معظم شعراء هذا الفن هم من عالجوه وعاركوه ، ويمكن أن تئخذ عنهم وجهات النظرا لمعتبرة - فمن ذاق عرف - فكل الثعراء الذين مارسوا هذا الفن - المديح - تملكهم الزهو بشعرهم ، وأعلوا

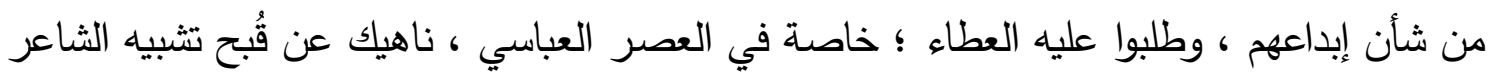

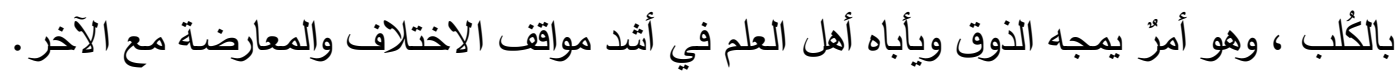

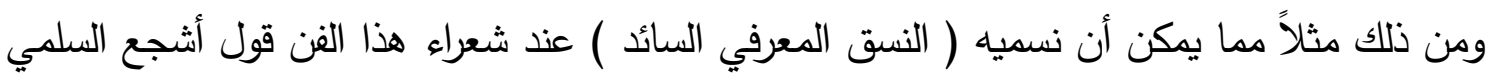

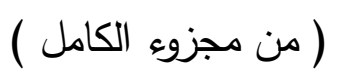

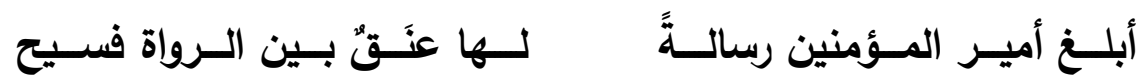

بأنَّ لسـان الثـعر ينطقه الندى ويخرسئسه الإبطساءُ وهـو فصـيح(') وقول أبي نواس :

صببثُ على الأمير ثيابَ مدحي فكلُّ الناسِ حسَّن واستجادا

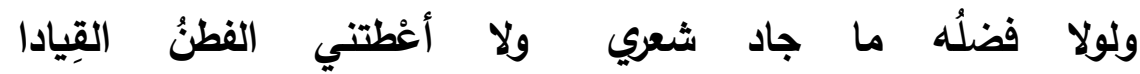

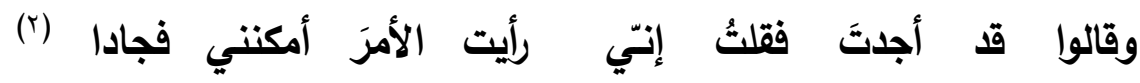

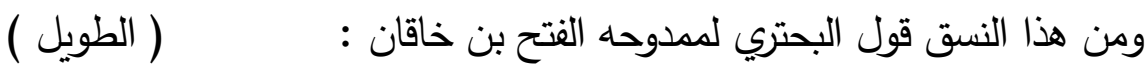

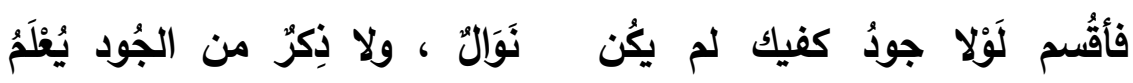

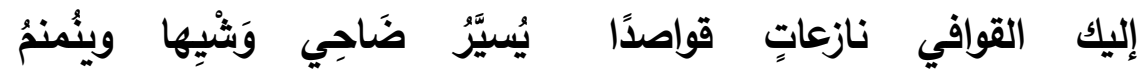

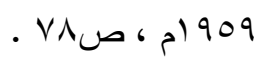

(') أثجع السلمي حياته وشعره ، د/ خليل بنيان الحسون ، دار المسيرة ، بيروت ، ط الأولى سنة إه ام ، ص/

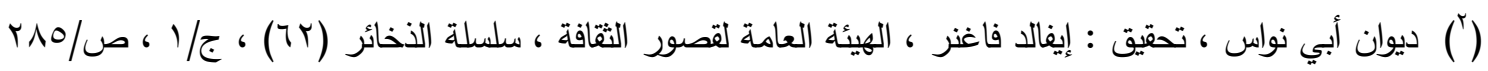




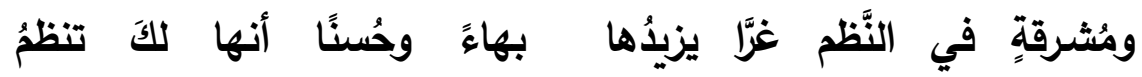
ضوامن للحاجاتِ إمَّا شوافِعًا مشفعةً أو حاكماتٍ تُكم

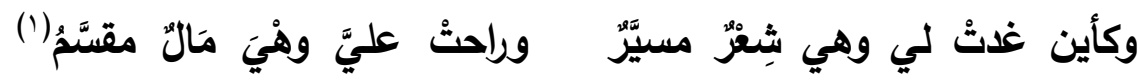

هذا وإذا كان الدديح عيبًا يُرد شعر الثاعر لأجله ؛ لما فيه من إساءة أدب ومذلة ... فلماذا استثهد

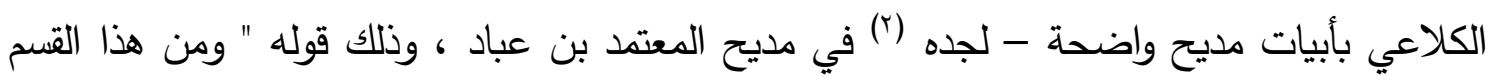

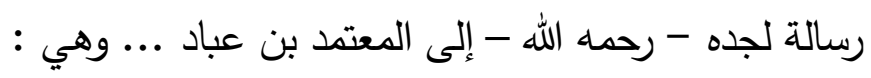

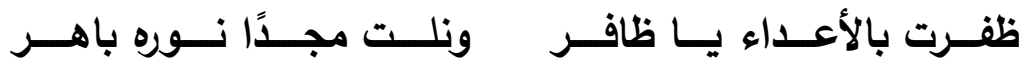

عَضبٌ جراز ، وندى غامر (r)

فمنك للباغي وللمبتغي فرد عليه المعتمد :

عنّت لنـا طير القربض الذي حكت ، فكان الأجدل الخـاطرُ

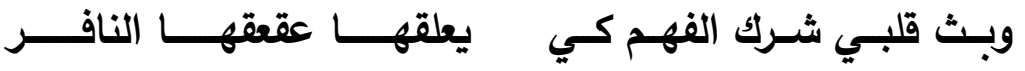

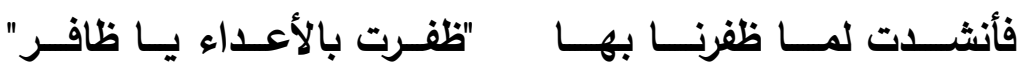

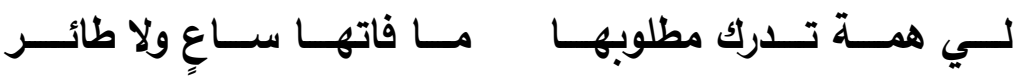

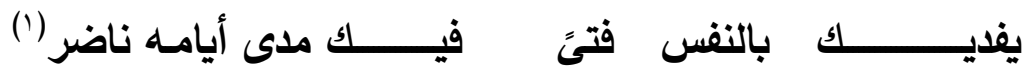

(') ديوان البحتري ، تحقيق وشرح : الثاعر / حسن كامل الصيرفي ، ط الثالثة سنة ـ 197 ، دار المعارف ، ج/\%، ص/.

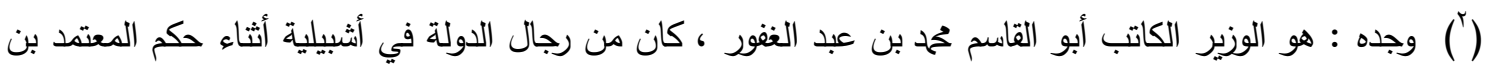

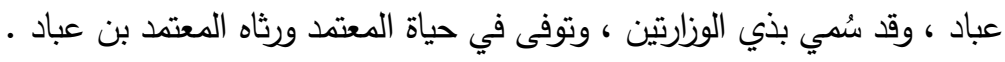

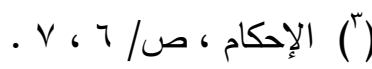


ومن تناقضه مع نفسه إجازته للاستمناح والطلب ( بالنثر الفني ) (؟) مع أن من معايب الثعر عنده

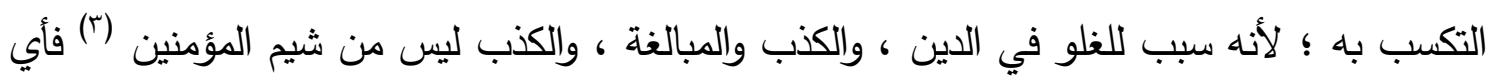

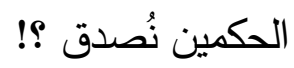

$$
\text { المطلب الرابع : تعدي الضرر الألبي من الثعر إلى النقد : }
$$

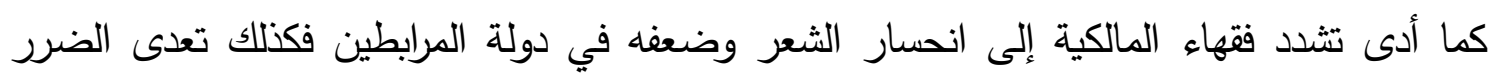

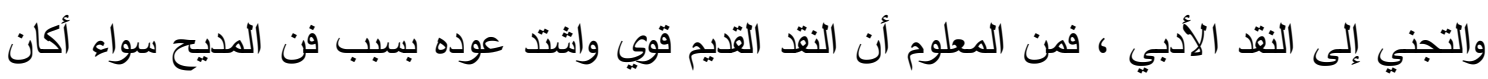

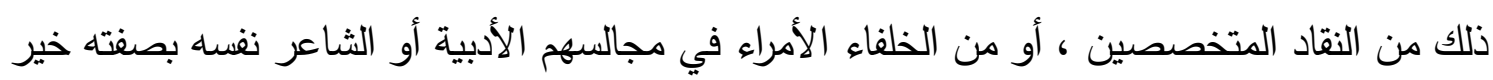
النقاد .

ومن ثم فإن ارتباط المديح التكسبي بالسلطة يعد من أهم البواعث لقوة النقد(؛) ، فقد نثأت معظم

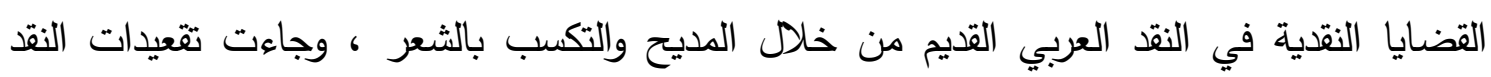
مرتبطة بهذه القصيدة المدحية (0). وهذا خير كله أثرى الإبداع الثعري ، والإبداع النقدي كذلك ؛ لأن هؤلاء النقاد " نظروا إلى شعر

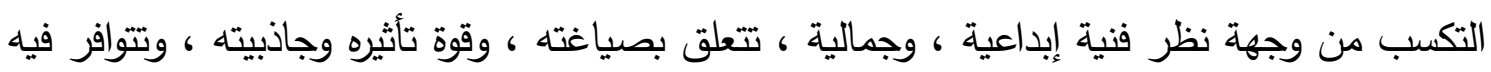

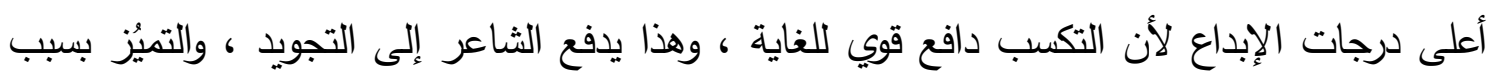

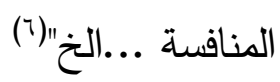

وقد تجلى أثر قصيدة الددح التكسبي في النقد بوضوح خاصة عند نقاد القرن الرابع الهجري من أمثال

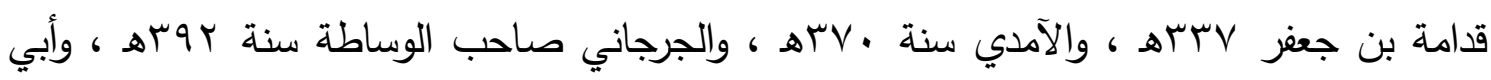

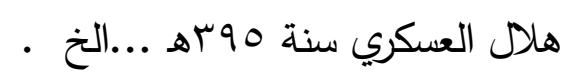
ولكننا نجد الكلاعي بفكره الفقهي يضرب بهذا الموروث الإبداعي والفكري للنقاد القدامى عُرض الحائط

$$
\begin{aligned}
& \text { (') الأحكام ، ص/ 19 19. }
\end{aligned}
$$

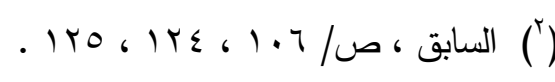

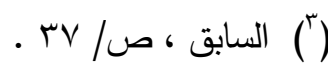

(أ) مفهوم الثعر في التراث العببي ، النثأة والتطور - د/ أحد حلمي عبد العليم ، سلسلة كتابات نقدية ، الهيئة العلمية

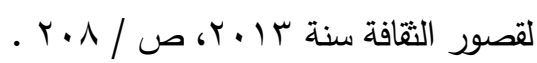

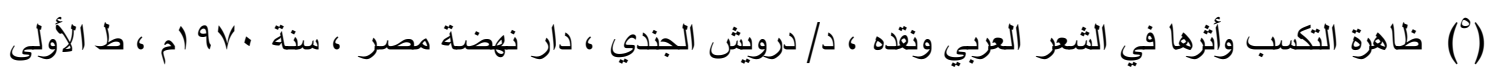

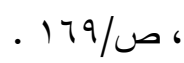

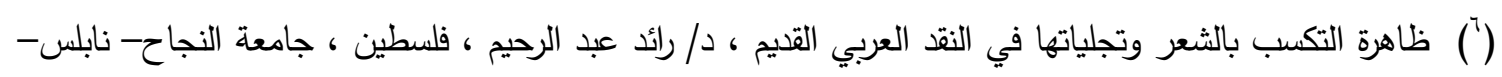

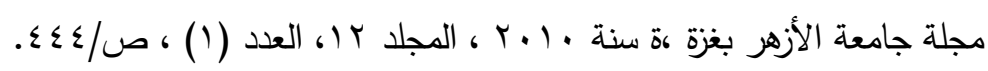


وكأنه يؤسس لنقد جديد ؟! لأن شعر التكسب بالأصل كما يدعي هو " سبب لطلاقة اللسان في قول الزور، والخوض في

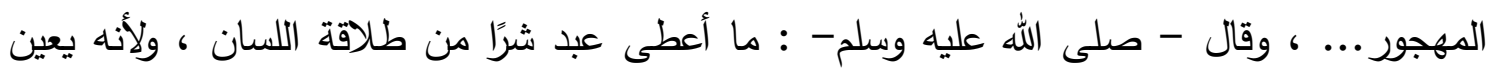

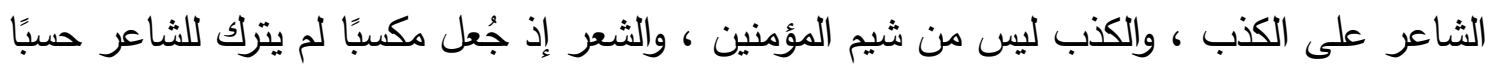

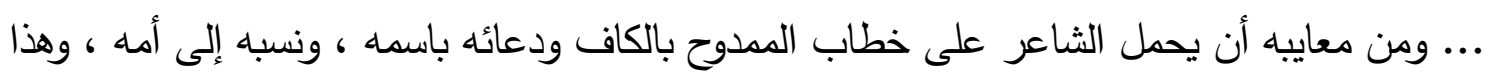
كله من سوء الأدب أو داعيًا إليه ... " ('). هكذا وبتعقيد المتعصبين فكريًا والمتعصبين لمعتقداتهم نجد الكلاعي يعُد الجهود النقدية لعلماء النقد

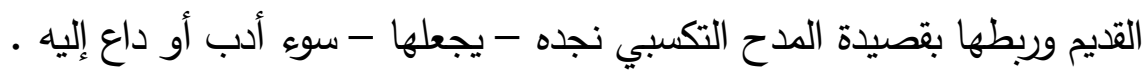

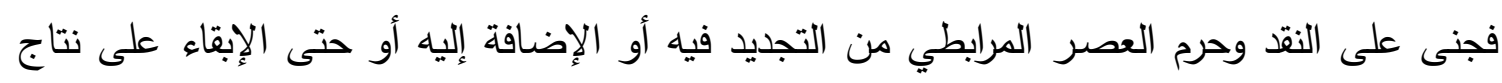

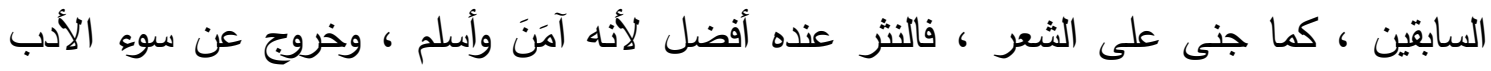

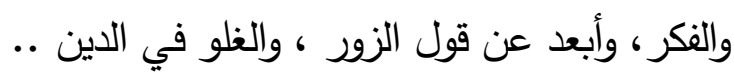

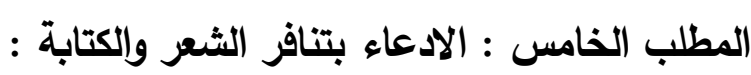

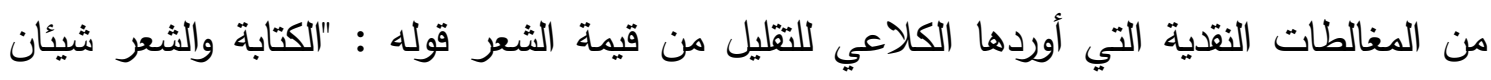

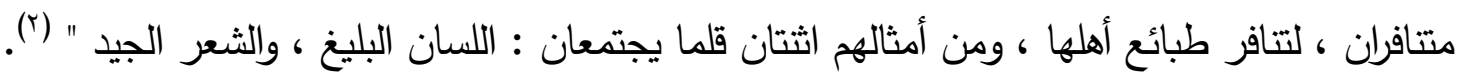

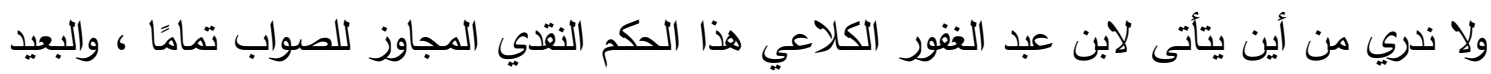

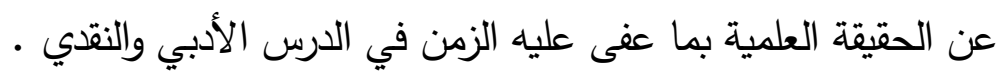

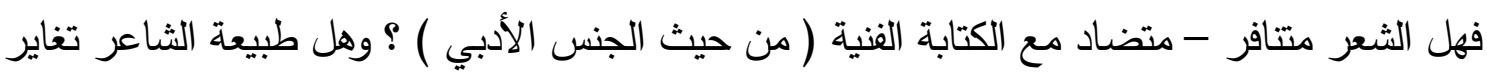
وتختلف مع طبيعة الكاتب ( من حيث المبدع نفسه ) ؟

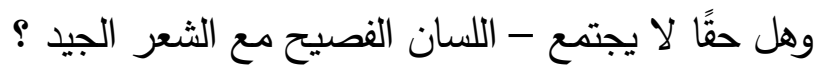

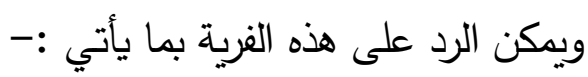
- من خلا عصر ( الكلاعي نفسه ) وليس بعد العين أين ، كان الكُّاب النابهون النين هم بالأصل

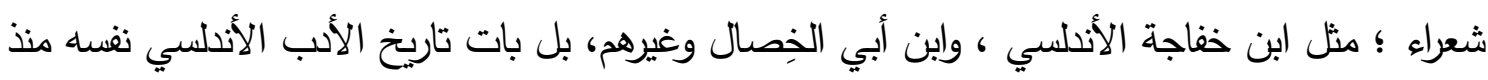

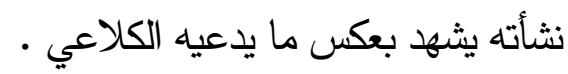
فكم كان هناك من الثعراء الذين أجادوا الكتابة في بلاط الأندلسيين مثل ابن الأبّار ... وغيرهم الكثير (")

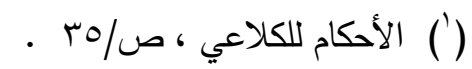

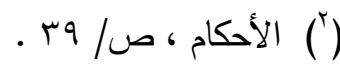

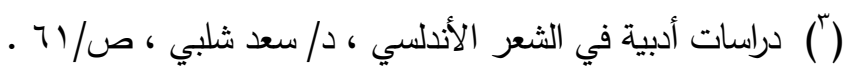




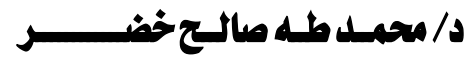

ولذا يقول د/ السيوفي : " ويندر في التاريخ الأدبي الأندلسي أن نجد شاعرا لم يعالج الكتابة الفنية في كثير من معانيها وأغراضها " ('). - والمفارقة الأعجب أن بلاط يوسف بن تاشفين زعيم دولة المرابطين كان مكتظًا بفقهاء المالكية ، وبالكثير من الشعراء الكتاب ؛ ومن هؤلاء الثعراء الفقهاء أبو عبد الله بن عائشة ؛ والكلاعي نفسه كان في المقام الأول شاعرًا كاتبًا فقيهًا ، في بلاط ابن تاشفين يقول الكلاعي عن شاعريته : " كنت مولعًا بترصيعه وتصنيعه ، مائلاً في تقريطه وتشنيفه إلى مرتبة كنت أعدها أعلى المراتب ل. . . فنزعت منزعًا كريمًا من علم الديانة ورفضتُ الثعرَ رفض الشعلة للزناد" ، واقتصرت على الكتابة لأنها

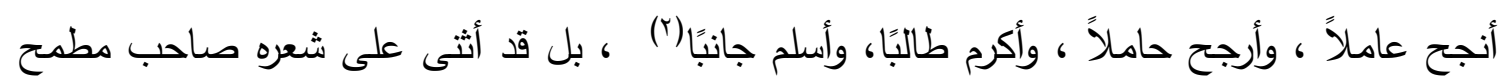
الأنفس قائلاً : "وله شعر بديع السرور ، مفوف البُرد ... " (r). وثالثة الأثافي أن ما ذكره الكلاعي من المناظرة المقحمة والاختلاف المزعوم بين الكتابة والثعر، يرفضه النسق العام للفكر السائد في الدرس الأدبي والنقدي منذ القدم ، وذلك عند الوقوف أمام (الكئ

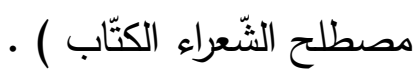
فكثير من الثعراء عُرفوا بالكتابة ، والعكس منذ العصر الجاهلي مثل : عدي بن زيد الثاعر الكاتب في البلاط الحيري ، ولقيط بن يعمُر الإيادي ، والمرقش الأكبر وتثتد الظاهرة في العصر العباسي من أمثال : الفضل بن سهل ، وأخيه الحسن بن سهل من الشعراء الكتاب في بلاط المأمون ، وحمح بن عبد الملك الزيات كاتب المعتصم ووزيره ، وابن العميد ، والصاحب بن عباد ، والصابئ ، وكثاجم ..

وغيرهم الكثير ممن شاع ذكرهم خاصة في القرنين الثالث والرابع خاصة من العصر العباسي(؛). - قلت وشاعرية اللغة النثرية - عند الكُتَاب - والتي مبعثها أن هؤلاء في الأصل شعراء ... هي السبب الأقوى في تفضيلهم على غيرهم عند السلطة الحاكمة ... لأنهم لسانها ، ولذا دخلوا " الدواوين وأصبحت لهم الحظوة " يقول الجاحظ ت سنة ب00هـ : في عمق معرفة الكُتَّاب بالثعر ونقده .

(') تاريخ الأدب الأندلسي ، د/ مصطفى السيوفي ، الدار الدولية للاستثمارات الثقافية ، القاهرة سنة ^ ..بم ، ص/

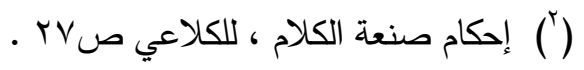

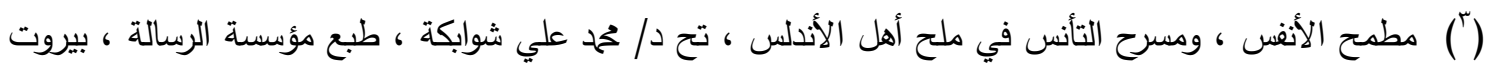

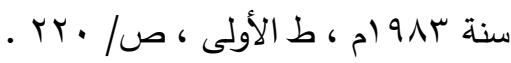

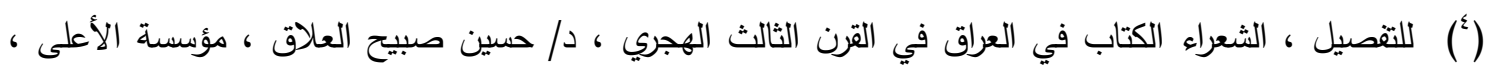

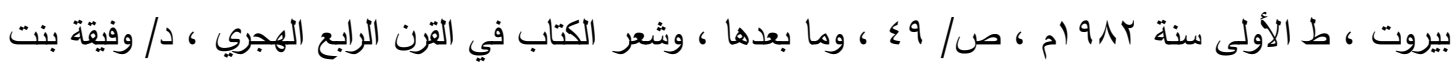

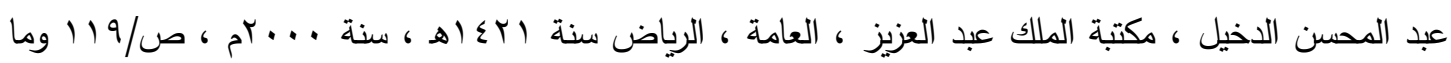


" طلبت علم الثعر عند الأصمعي فوجدته لا يحسن إلا غريبه ، فرجعت إلى الأخفش فوجدته لا يتقن

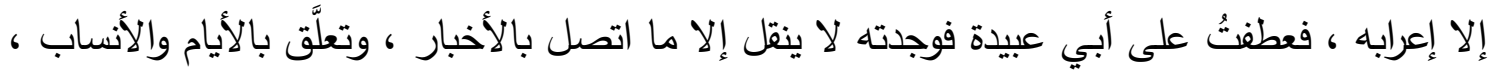

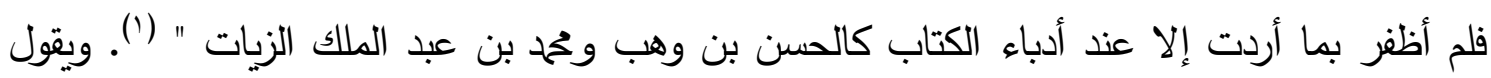
أيضًا : فلم أرقط أمثل طريقة في البلاغة من الكتاب ، فإنهم قد التصسوا من الألفاظ ما لم يكن متوعرًا وحثيًا ولا

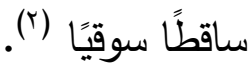
ومنهم المرزباني (ت ع عاهـ ) في معجمه حيث ترجم لعدد كبير منهم (r).

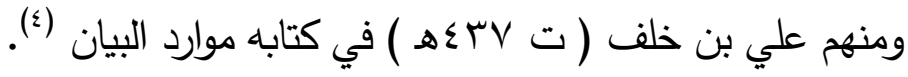

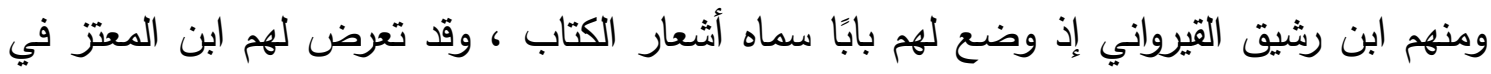
الطبقات ، وكذا ابن الجراح صاحب كتاب الورقة . ومنهم الجهشياري ت سنة استهـ (0).

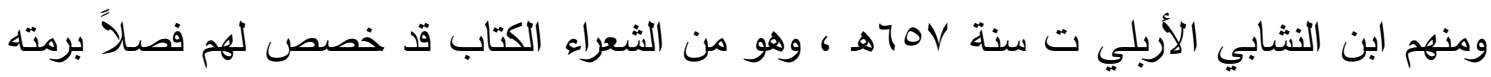
تحت عنوانه " شعراء الكتاب " (?). - ويقوي ذلك كله ويعضده وينكر على الكلاعي قوله ويرده عليه قيام رسالة دكتوراه برمتها حول شعر

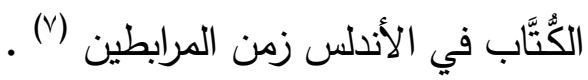
وكل نلك يدحض رأي الكلاعي ويؤكد أن لا منافرة ولا اختلاف ولا مشاحة بين الثعر والكتابة ، بل هما متكاملان،

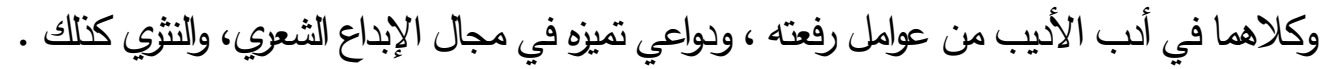

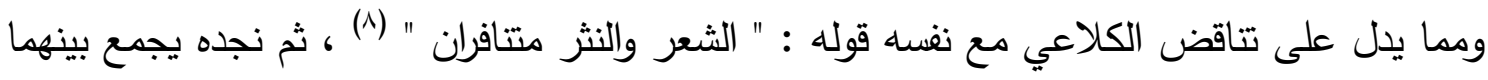

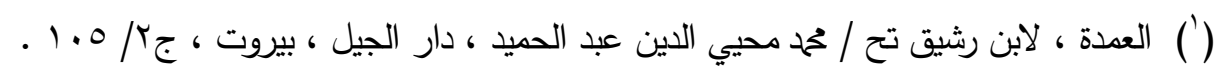

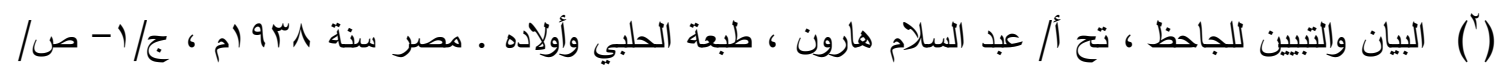
$.1 T \mathrm{r}$

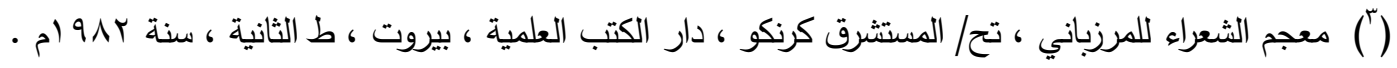

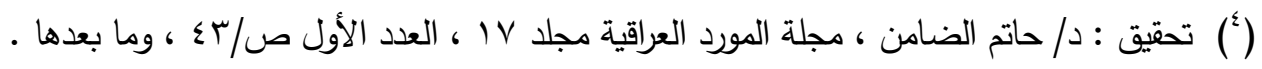

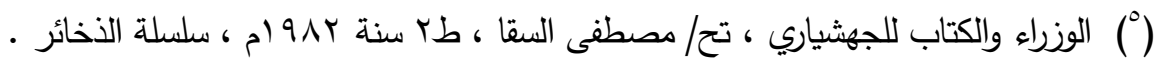

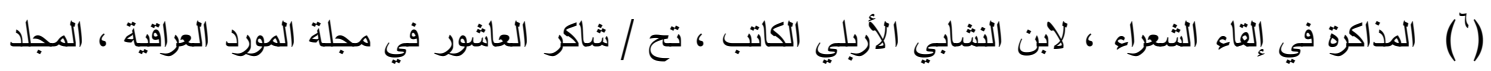

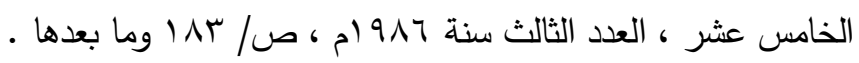

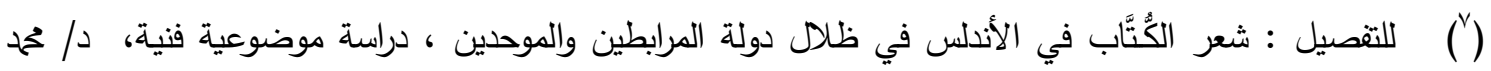

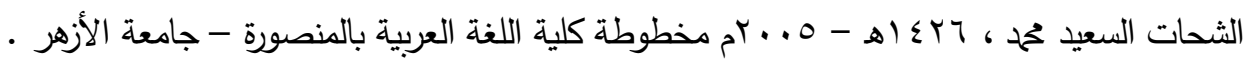

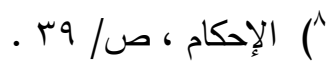




$$
\text { المطلب السادس عن : السجع عيب في الثنظوم ) . }
$$

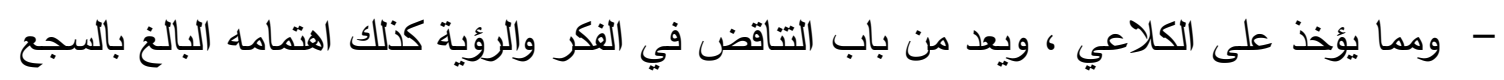

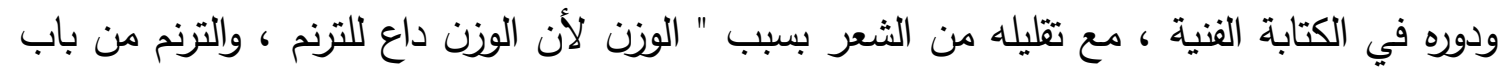

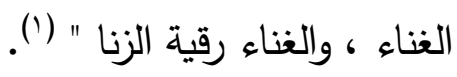
ولذلك فالثعر طريق لسوء الأدب بسبب الوزن ؛ ثم يعقب مباشرة بعد هذه الفقرة السابقة بقوله " وأما

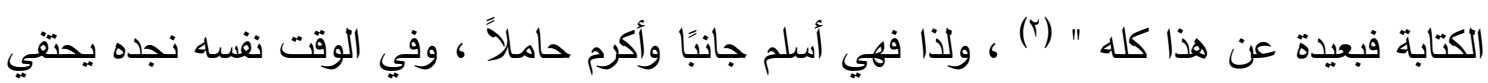

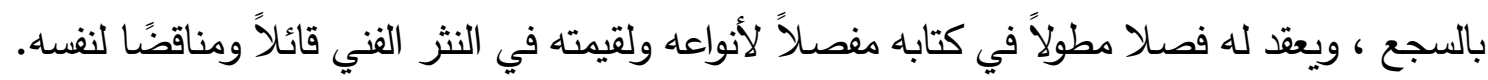

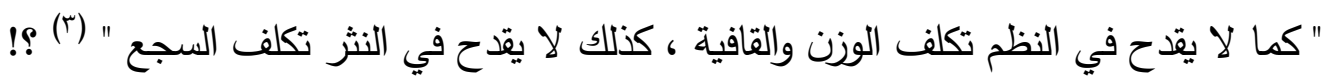

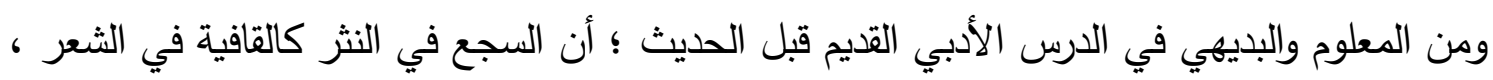
والقافية هي تاج الموسيقى الخارجية في العمل الثعري ومنها يحثث النظم والترنم ، وهو عينه ما تتركه الفواصل على اختلافها في السجع مع النثر - ولذا يقول العلماء :

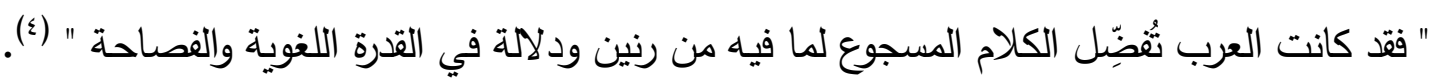

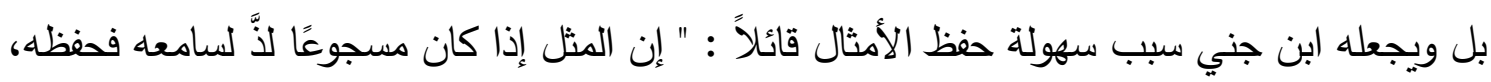

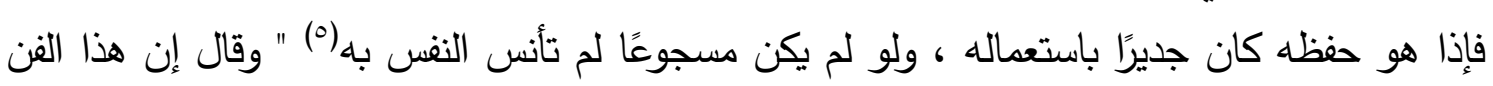

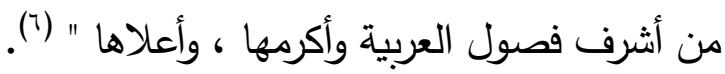

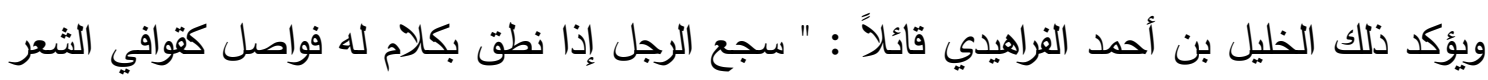

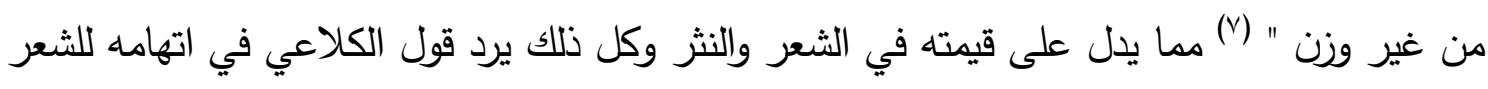

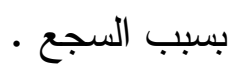

$$
\begin{aligned}
& \text { (') السابق ، ص/ یr . . }
\end{aligned}
$$

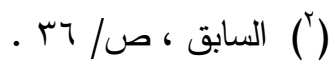

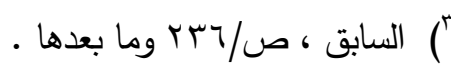

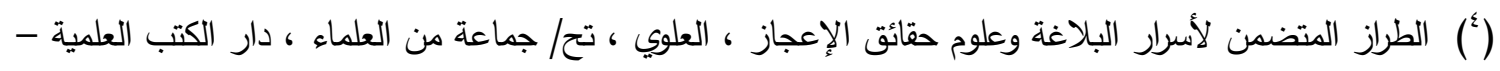

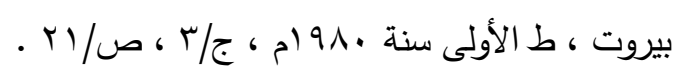

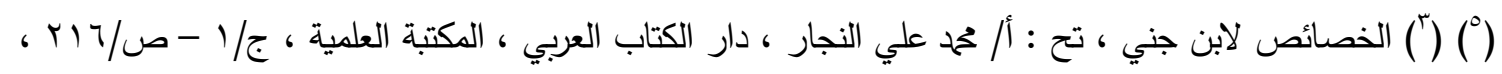
وما بعدها .

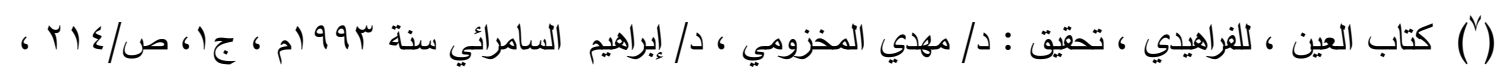
مادة (سجع ) . 
وهنا يثبت البحث بُعد الكلاعي عن النزاهة في عرض الأفكار لأسباب نفعية خاصة بطبقة الكتاب

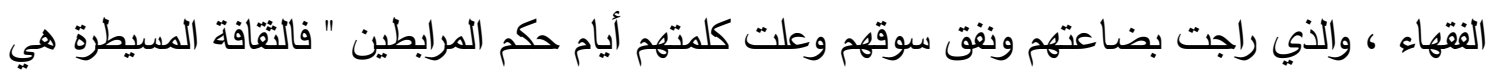
الثثافة النقهية والمكانة السامية في الدولة صارت للفقهاء " (1) وفي المقابل ضعف الثفاع الثعر وانحسرت مساراته . 


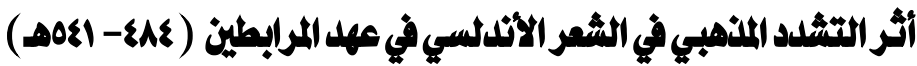

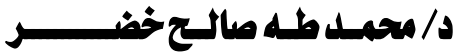

المبحث الثاني

تداعيات التثدد المذهبي وأثرها في حركية الثعر زمن المرابطين

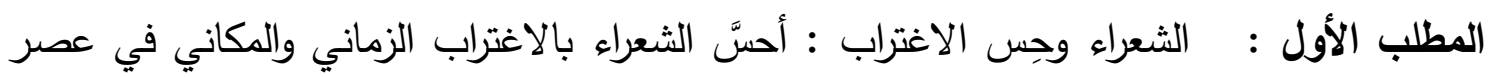

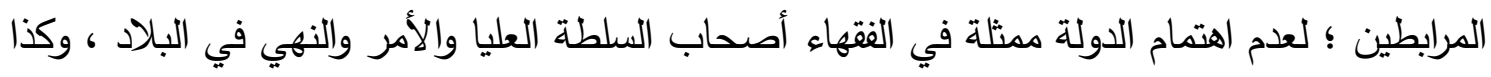

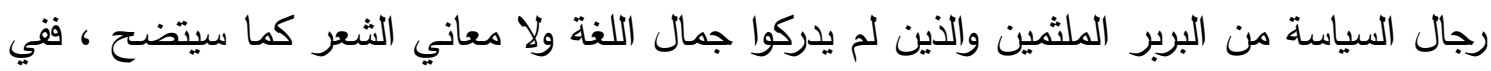

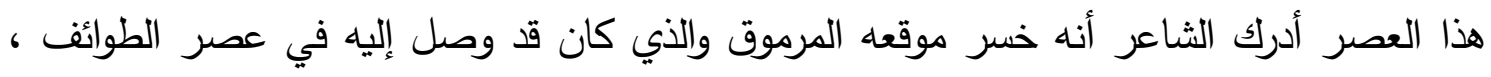

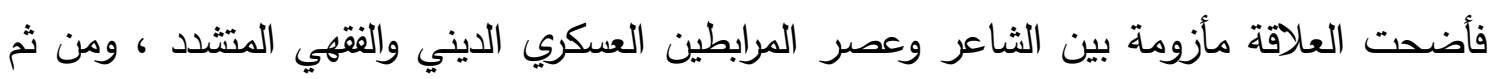
أحس إحساسًا مهينًا بالنقص والتهيش ففي هذا العصر ( ضاع الأدب والثعر خاصة ل... إذ أهملته

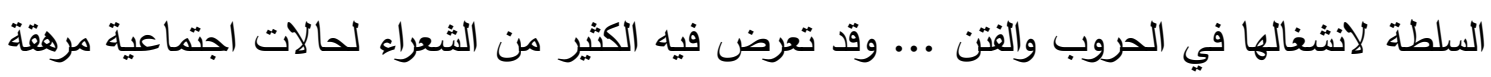

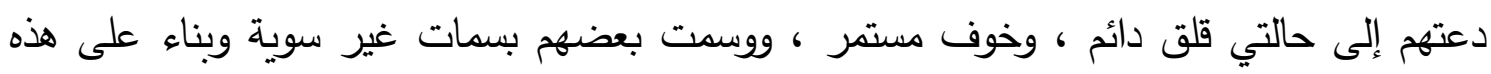

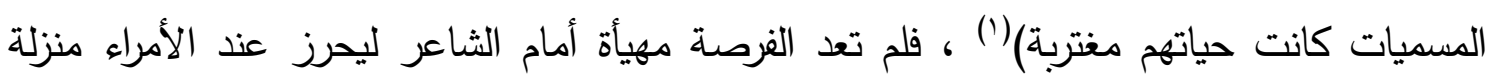

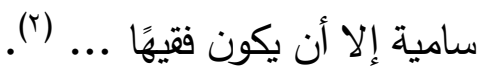
ولا عجب في ذلك فطبيعة الملثمين - المرابطين- الخشونة والقسوة في سلوكهم وتصرفاتهم فقد اعتادوا

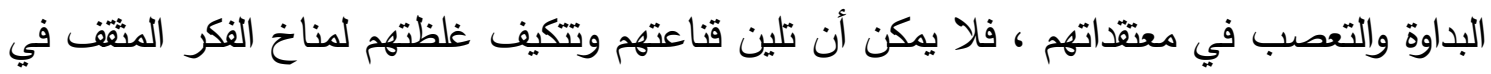
الأندلس ... (r) وبذلك نُوقن أن الثعر لم يكن بضاعة رائجة للأدباء بوجه عام ؛ أي أن شعراء البلاط الذين ينتظرون

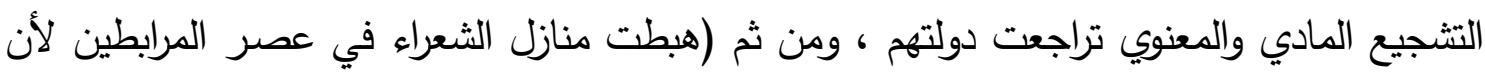

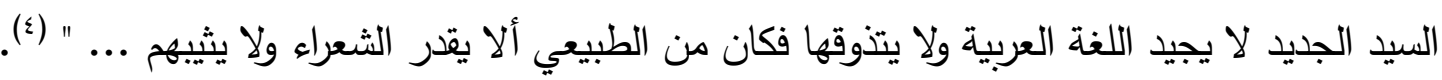

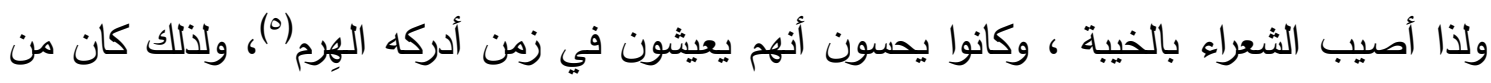

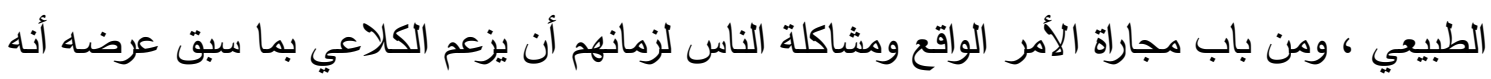
ترك الثعر تديناً وتنسكا ويفضل عليه النثر خاصة فن الكتابة السلطانية والخطابة . والمقصد أن انحسار الثعر وضعفه بسبب هذا التثدد من أتباع الدذهب المالكي في دولة المرابطين

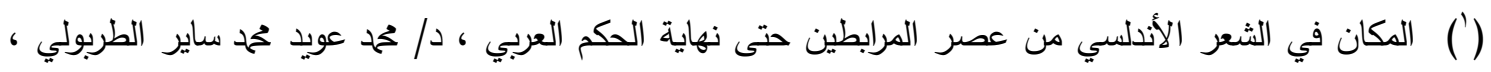

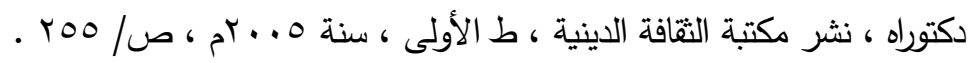

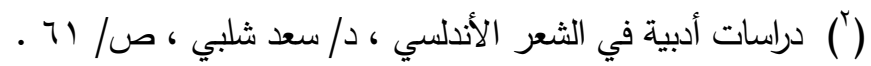

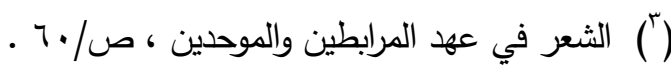

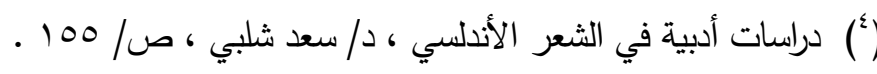

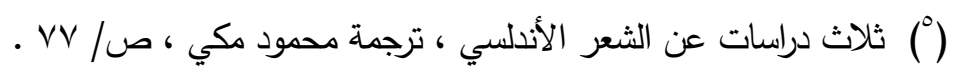


جَنََّ على مرحلة هامة من شعرنا العربي كان المتوقع لها الازدهار والرقي خاصة بعد دولة الطوائف ،

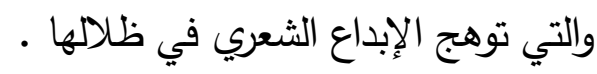

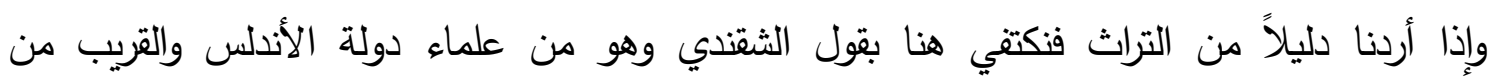

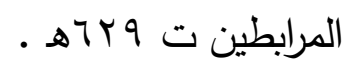

يقول الثقندي(') في رسالته التي فاضل فيها بين الأندلسيين والبربر المرابطين: " ولولا توسط ابن عباد

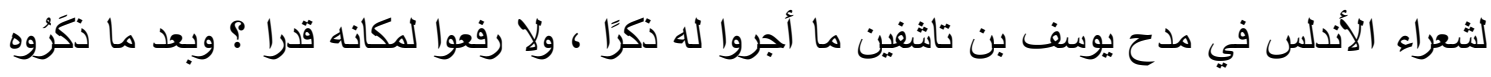

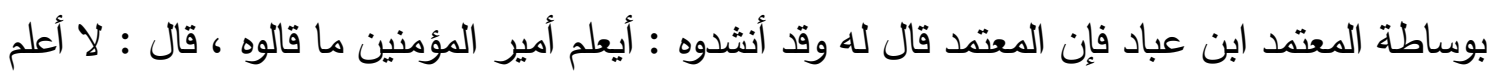

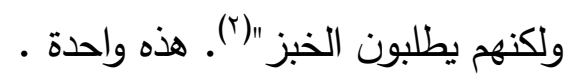
ويقول أيضًا : ( ولما انصرف عن المعتد إلى حاضرة ملكه كتب له المعتدد رسالة فيها : (البسيط )

بنتم وبِنّا فما ابتلَّت جوانحنا شوقًا إليكم ولا جفّتْ مآقينـا

حالت لفقدكُمُ أيامنا فغدتُ سودًا وكانت بكم بيضًا ليالينا

فلما قُرئ عليه هذان البيتان ؛ قال للقارئ يطلب منا جواري سودًا وبيضًا ؟ ، قال : لا يا مولانا ، ما أراد

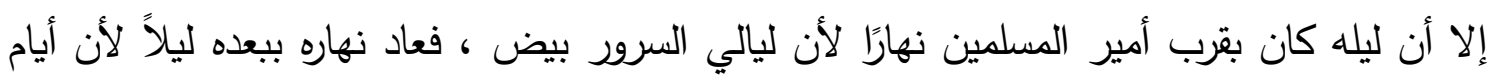

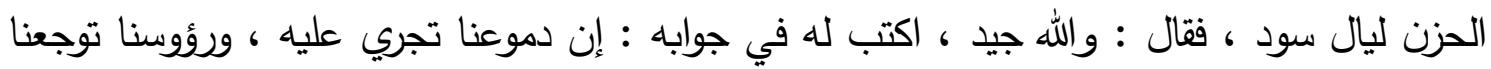

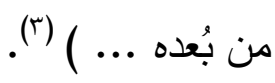
وهذا النص التراثي من ناقدٍ ، وشاعر ، وعالم قريب من زمن المرابطين ليؤكد أن المرابطين اتسموا حقًّا

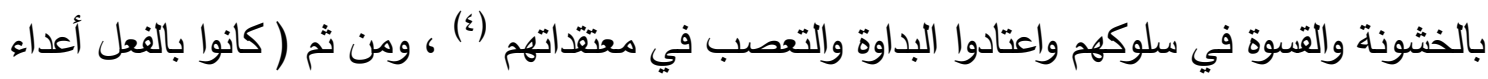
طارئين على الثعر الأندلسي ) (o). فقراءة النص السابق قراءة تحليلية بعد دراسة حالة العصر دراسة مستفيضة نستنتج منه الآتي :-

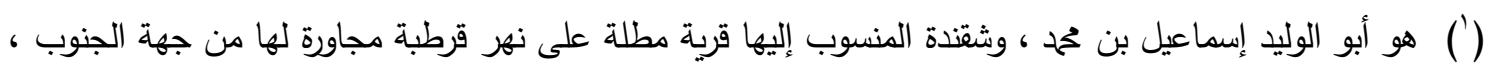

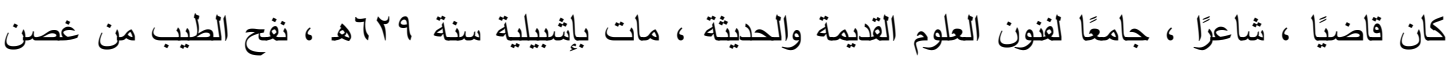

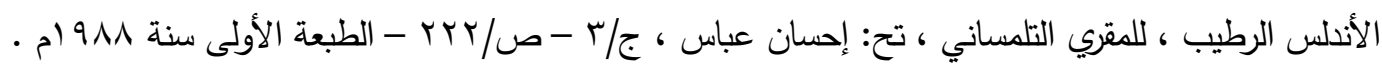

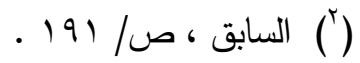

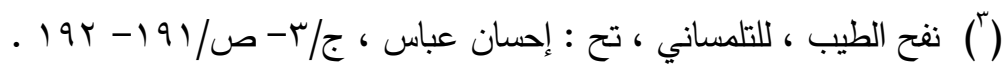

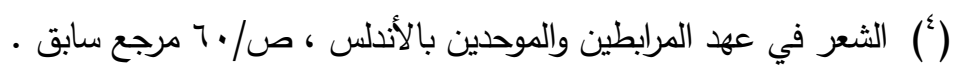

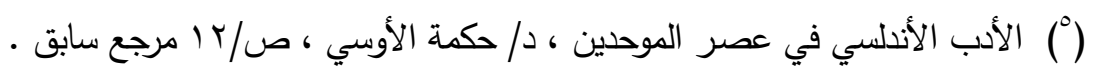




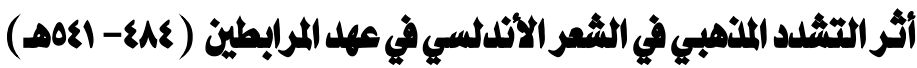

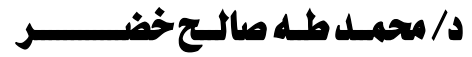

* لم يبادر الثعراء إلى مديح يوسف بن تاثفين - أمير دولة المرابطين في الأنلس - لعدم تذوقه وفهمه لما يقولون لولا تدخل المعتمد بن عباد فمدحوه مجاملة .

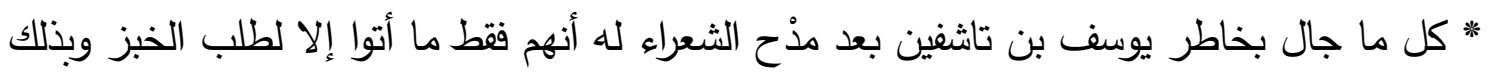

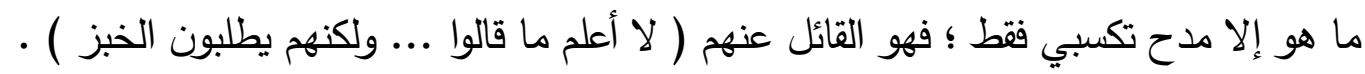
* إذ لم يكن يُحسن قراءة الثعر إذ كان له قارئ يقرؤه له . . له

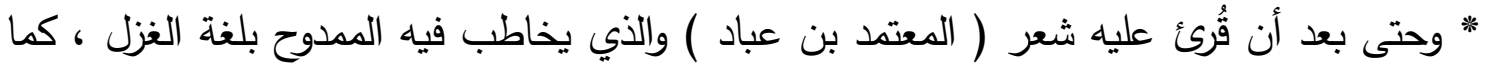

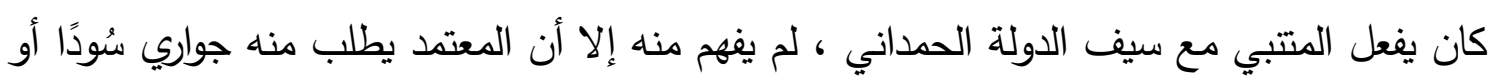
بيضًا * نلاحظ الخشونة والثدة في رد التحية في دار ابن تاشفين على تحية المعتمد له ـ وما أعتقده إلا

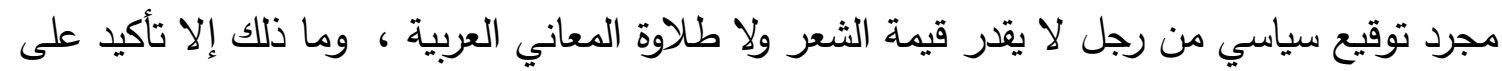

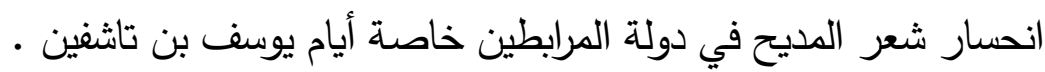

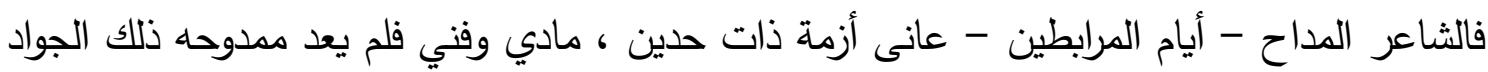
الذي يهب على الإبداع ، ولا يقدر قيمة ما يُلقى في حضرته.

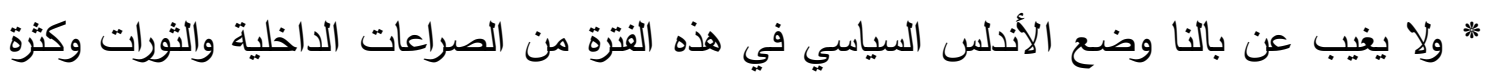

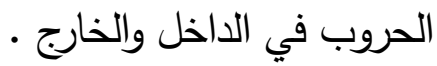

ومن ثم أضحى " الثعراء يعيشون في زمن أدركه الهرم ، فلم يعد لهم فيه مكان"( اله

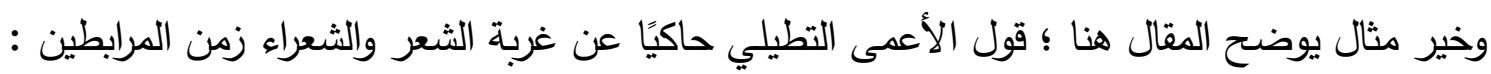
( من الطويل )

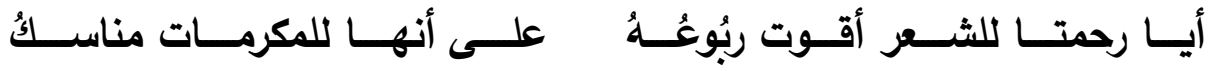

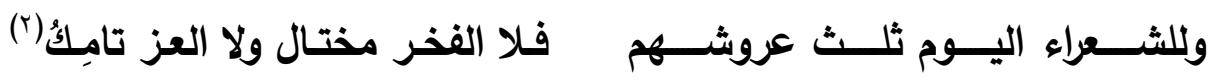

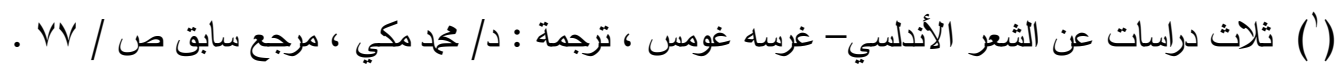

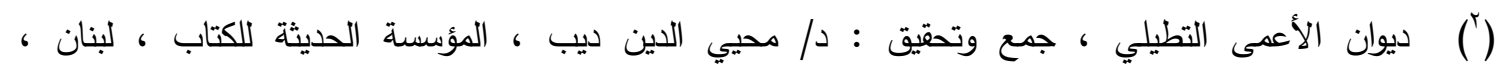

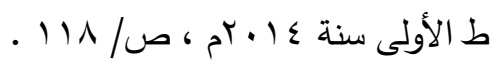


( من البسيط ) وقوله في معرض خطاب العاذلة :

أن العتابَ شجي في القلب أو شجبُ البطي

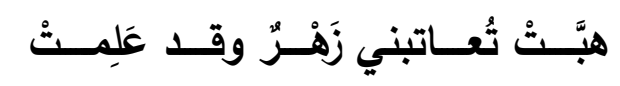

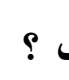

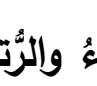

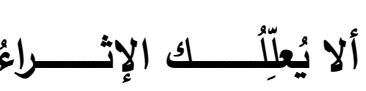
قالـت : قعـدت ، وقـام النــاس كُلُّهـُ فـي أنْْــة ضــاعَ فِي أثنائهــا الأدب

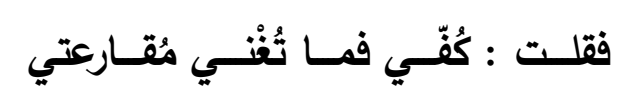
فاستضحكت ثم قالت : أنت في سعةٍ من أن تسيم ، وهـا المساء والعُشـب

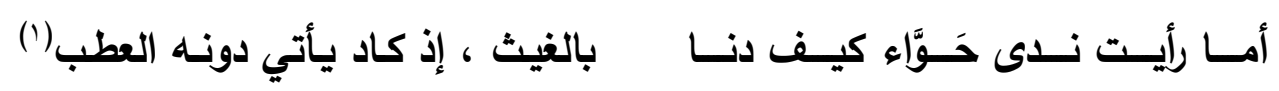

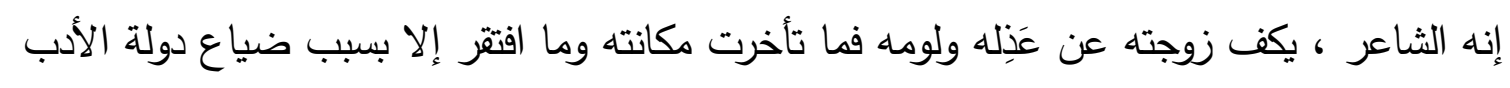
تحت سطوة الفقهاء ، وقسوة طباع البربر وخشونة ذوقهم المتلبد الجاف واليابس العاطفة والدتحجر المشاعر عن فهم الشعر وتذوقة . ومنه شكوى الثاعر ابن بقي(r) الأندلسي في زمن المرابطين ( والذي كان لاغترابه صدى طيب

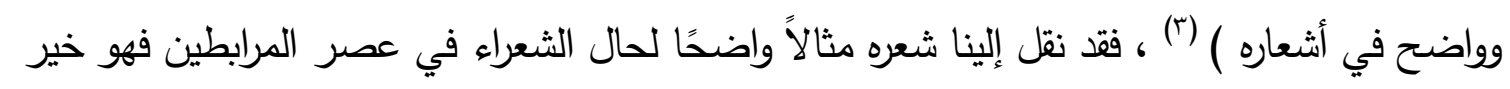
مثال ( للتشرد والضياع بأقصى صوره فلم يعرف طوال حياته الاستقرار .. وكان كثير الثكوى والتبرم

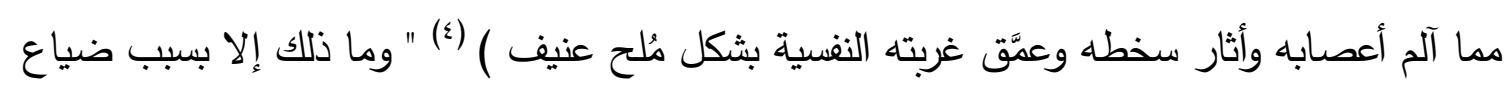

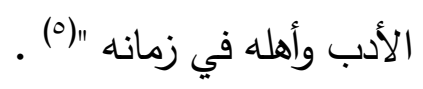

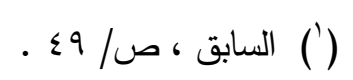

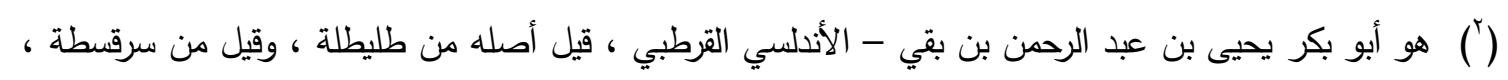

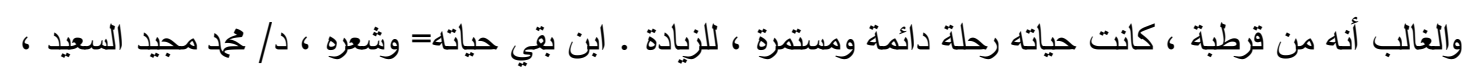

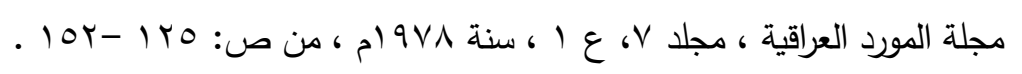

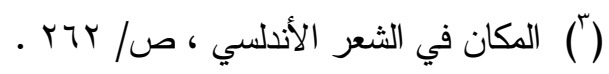

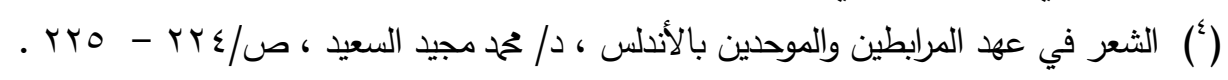

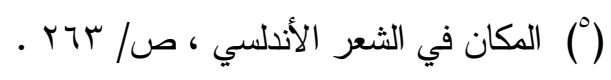




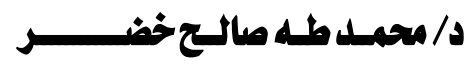

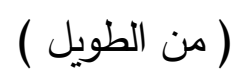

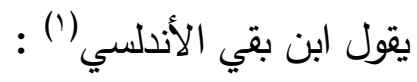

أُكـل بنـي الآداب مثلـي ضــائع؟! فأجعل ظلمـي أسـوة في المظـالم

طلبت العلى من قبل حلّ التمـائم

أم الظـــم محمــول علــيّ لأنتــي

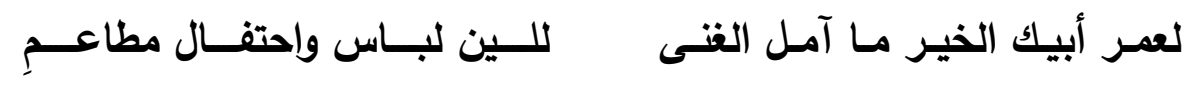

أسـر بهـا نفس الصـديق الملائم

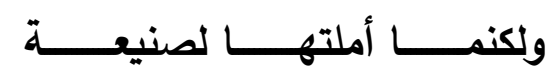

ستبكي قوافي الثعر مله جفونها علـى عربـي ضـاع بـين أعاجـم

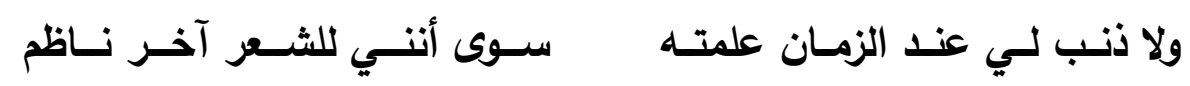

توهمتـه عمـرو بـن هنــ وخلتنـي شــقيا أتــاه مسن وفـود البـراجم

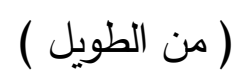

ويلاحظ قوله :

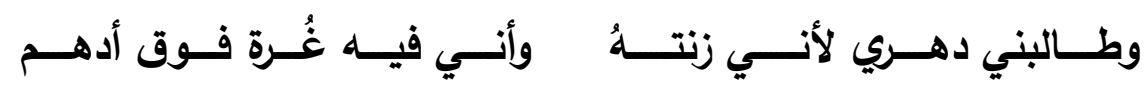

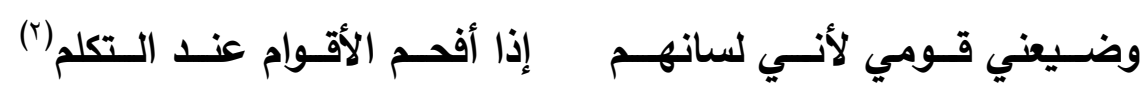

وهكذا نجد أن شعر الأعمى التطيلي وابن بقي وغيرهما ينقل إلينا وبصدق ما أحدثه عصر المرابطين

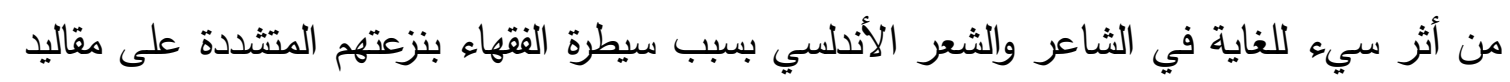

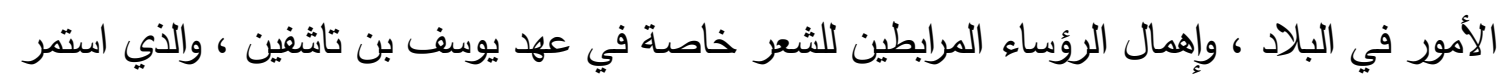

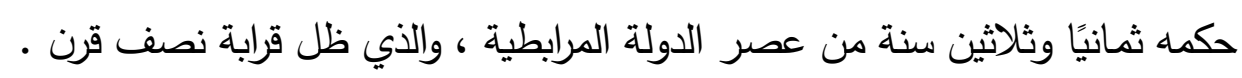

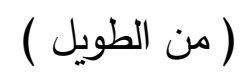
حتى قال الأعمى التطيلي فيهر :

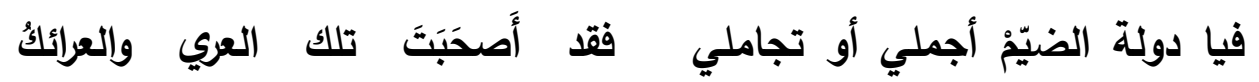

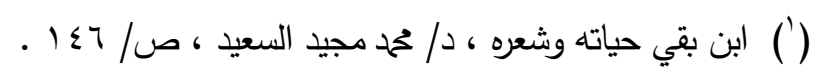

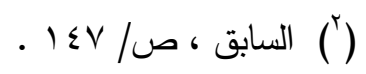




$$
\text { ويا " قام زيد" أعرضي أو تعارضي فقد حال من دون المنى : "قال }
$$

إثارة إلى سطوة الفقهاء المالكية بآرائهم المتثددة على البلاد " فقام زيد " رمزية للفكر اللغوي والإبداع

$$
\text { الشعري ( على عهد الطوائف ) ) }
$$

و" قال مالك " رمزية ساخطة لسطوة الدذهب المالكي وتثدده وموقفه من الفكر الفلسفي والثعري كما اتضح من خلال عرض آراء الكلاعي في إحكام صنعة الكلام ل... مع الأخذ في الاعتبار أن إحساس الثعراء بالاغتراب في زمن المرابطين كان سبيًا من ناحية أخرى في

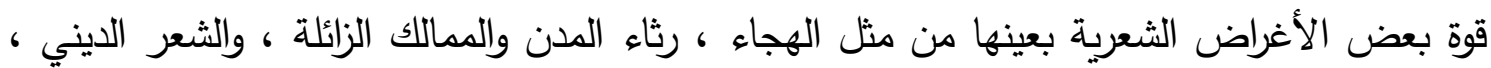
كما سيتضح في حينه .

(') ديوان الأعمى التطيلي ، تح وجمع / د: محيي الدين ديب ، المؤسسة الحديثة للكتاب ، لبنان ، الطبعة الأولى سنة

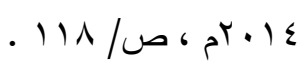




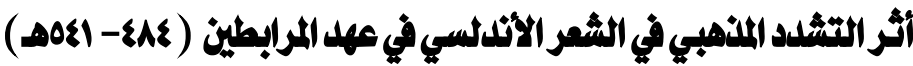

\section{د/ محمـلــــ ماكتح}

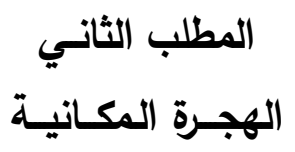

والتي ظهرت واضحة عند شعراء العصر مثل ما نجده عند ابن خفاجة الأندلسي ، والأعمى التطيلي ،

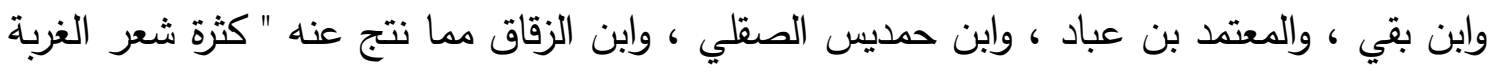
والحنين إلى الأوطان في عهد المرابطين " ( ). نعم لما بدا الثعر الأندلسي ، وكأنه يلفظ أنفاسه الأخيرة في عهد المرابطين .. وانطوى على نفسه إلى الى

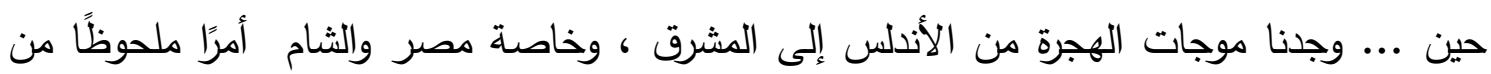

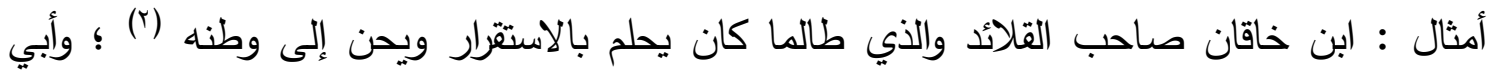

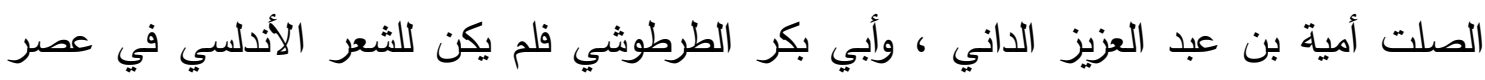
المرابطين محيص عن أن يضمحل ويعيش على ماضيه (r) .

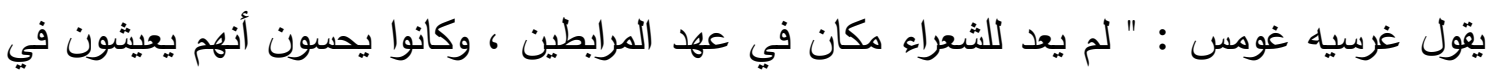

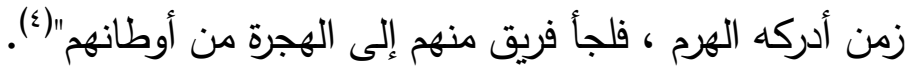

\section{المطلب الثالث \\ الهروب للثعر الثببي بدلاً عن الثعر الرسمي}

هرب الثعراء إلى بدائل عن الثعر الرسمي ، والذي اضمحل في عهر المرابطين إلى الاتجاه الثعبي

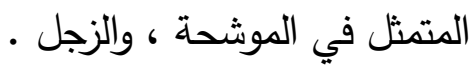
يقول د/ سعد شلبي : " وهناك ظاهرة جديدة بالاهتمام ، ولها دلالتها القوية على تأثر الثعر بالحالة

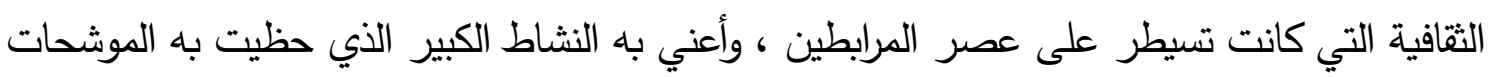

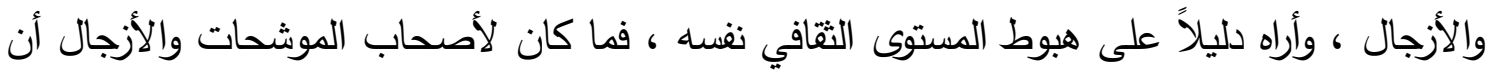

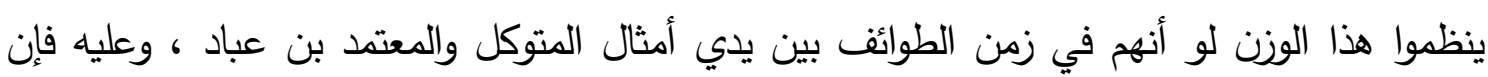

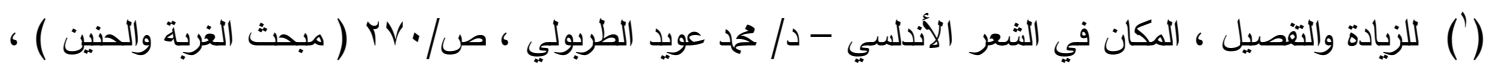

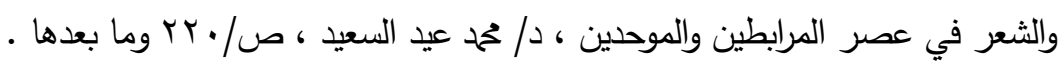

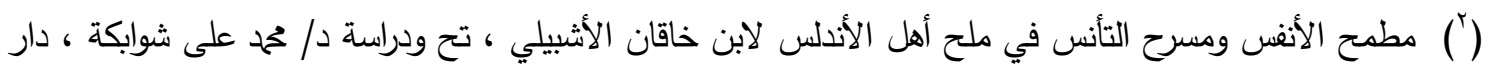

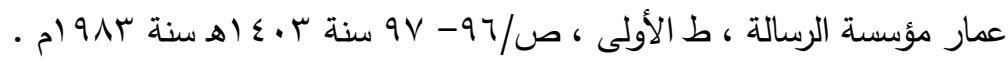

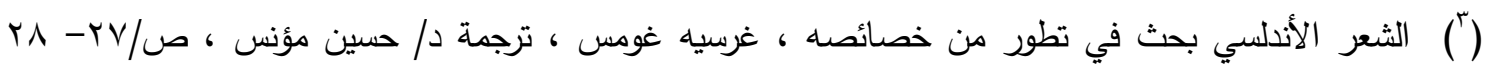

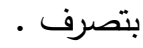

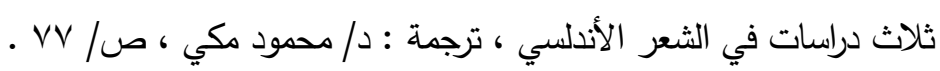


شيوع هذا اللون من الأدب دليل على طغيان ذوق العامة وانكماش ذوق الخاصة من عِلية القوم "(') ،

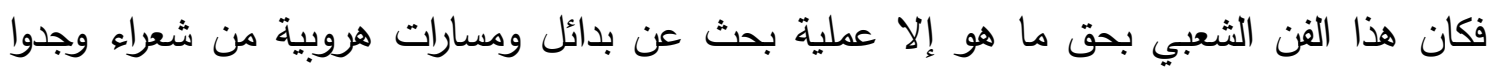
أنفهه مضطرين إلى استعمالها في العصر المرابطي الذي هبط فيه الذوق هبوطًا بالغًا (؟).

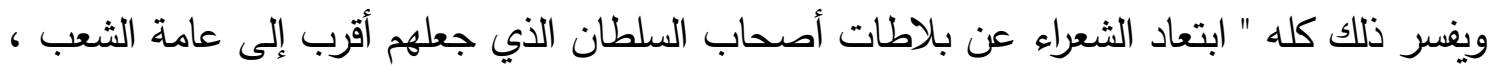

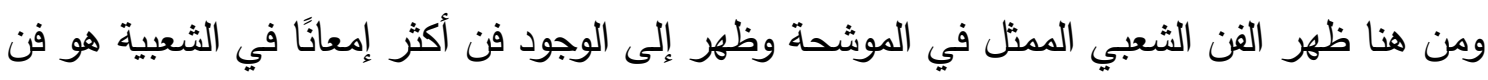

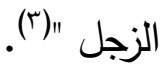
هذا والناظر في دراسة فن الزجل عند الأندلسيين في عهد المرابطين ليجد أن من أسباب ظهوره " عدم

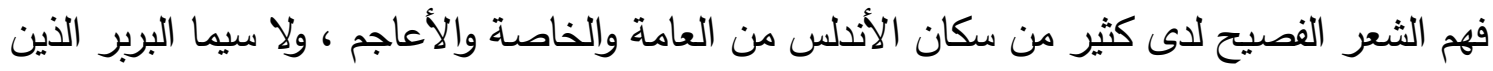

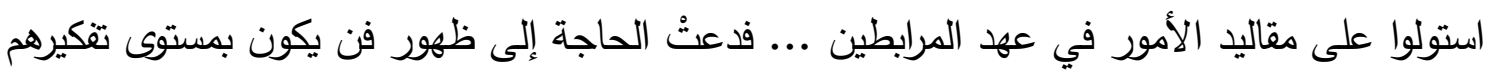

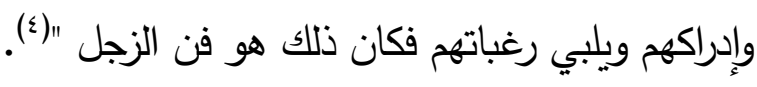
وخير مثال على ذلك ابن قزمان والذي لاحظ ضعف الثان الثعر الرسمي في عهر المرابطين فانتقل من

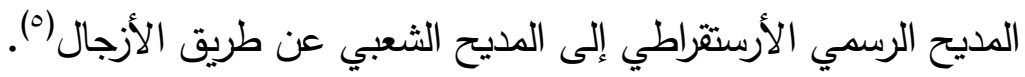

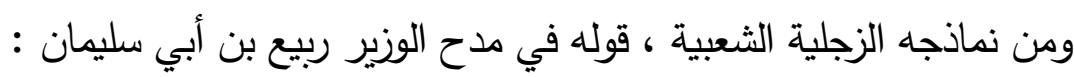

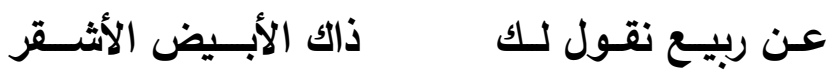

المشـــــاكل المنظـــــر

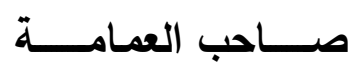

العلــو بحَــال الســكر

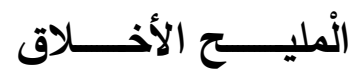

وللجــــــود فتـــــاك(7)

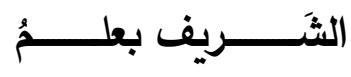

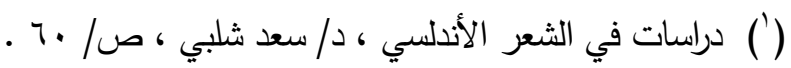

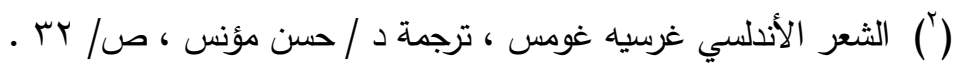

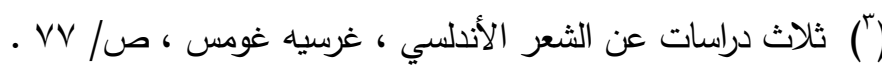

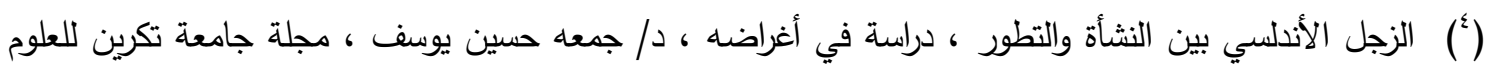

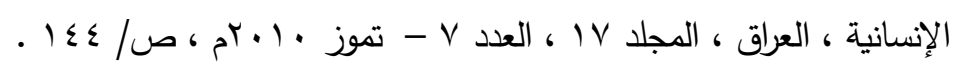

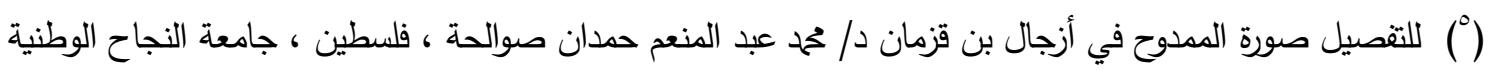

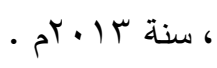

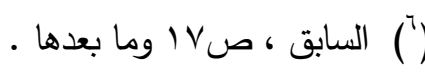




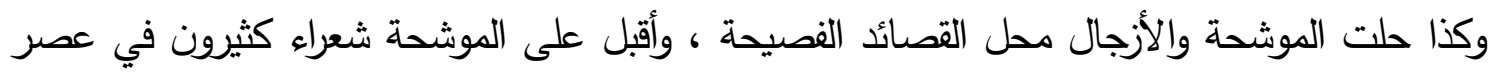

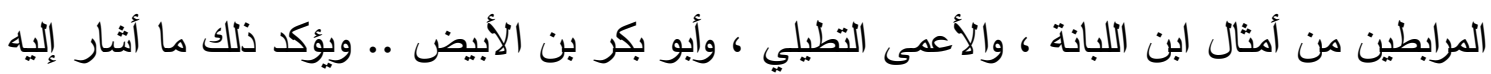

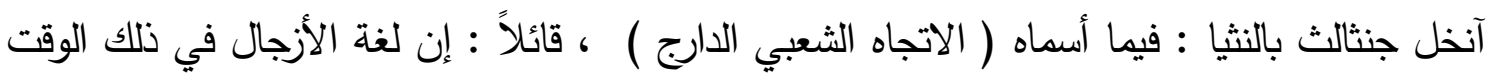

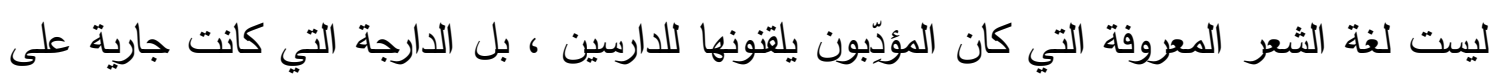

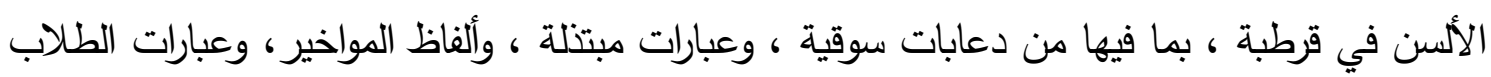

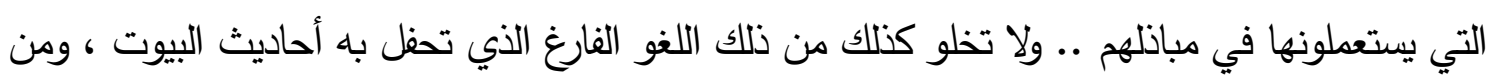

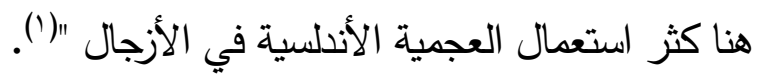

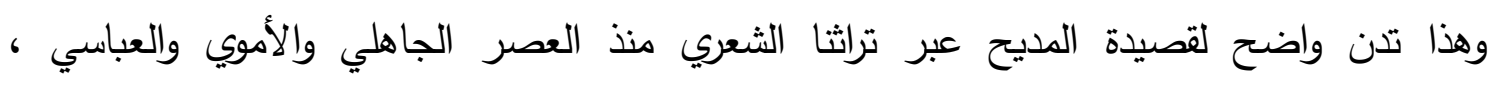

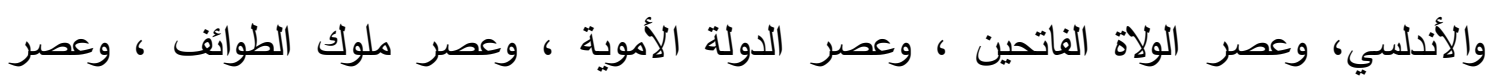
الموحدين وما بعده ... الأمر الذي يؤكد تراجع الثعر في عصر المرابطين من ناحية ؛ وخاصة شعر المديح كبناء هام مؤسس لحركة النص الثعري ونقده على مدار الثعر العربي .. فالثاعر في عصر المرابطين أصبح يقول ما شاء في هذا الفن ، لأنه في مأمن من النقار لأند الأدبي

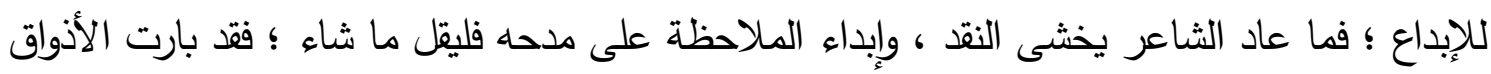

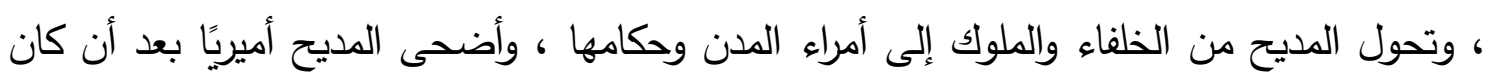

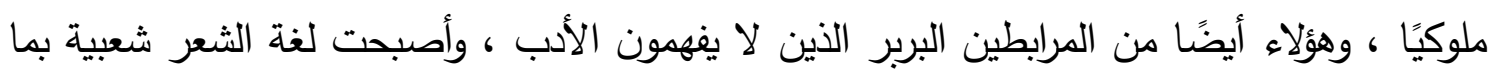

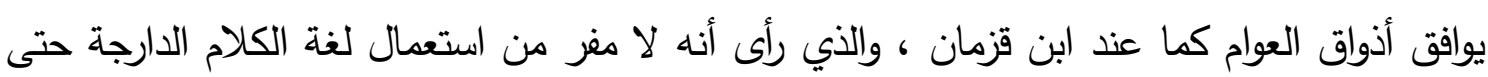

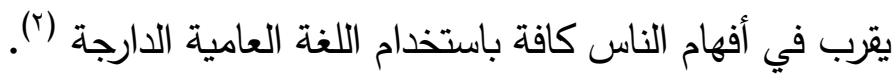

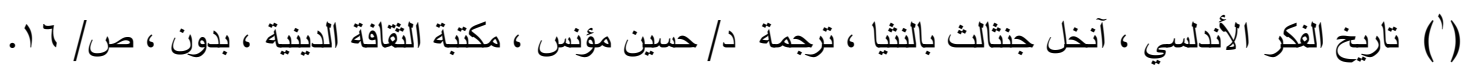

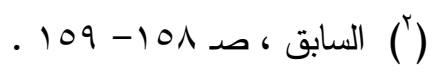




\section{المطلب الرابع \\ التأليف في تاريخ الأبب بدافع الخوف من ضياع دولة الثعر من المرابطين}

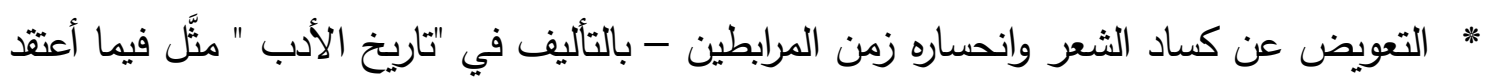

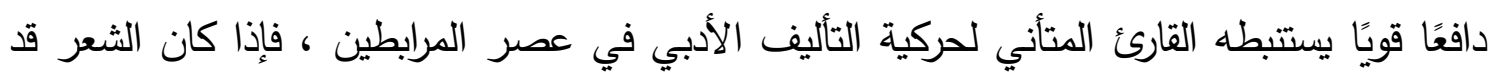

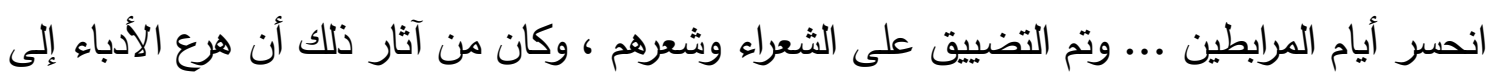

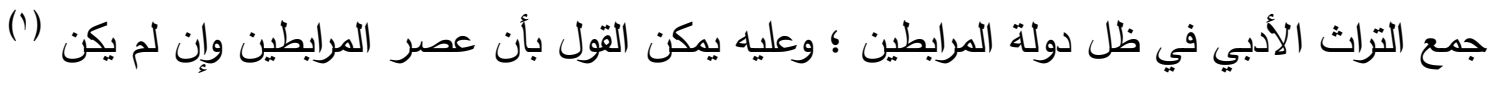

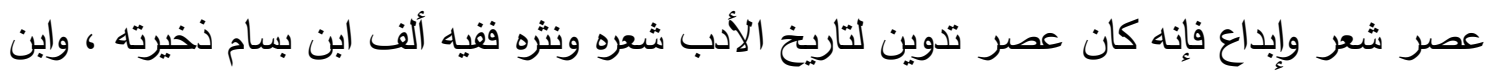

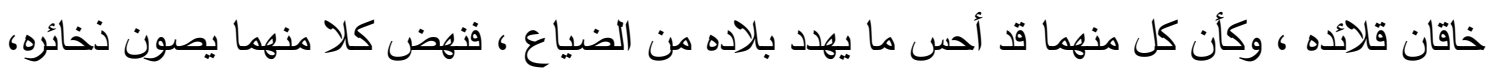
ويخلد كنوزه (r).

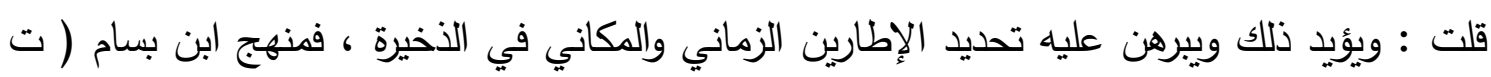

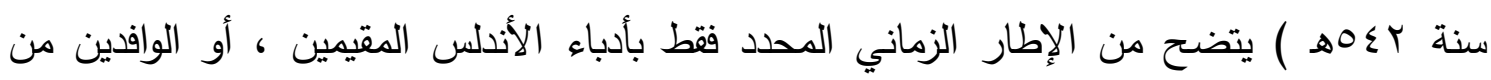

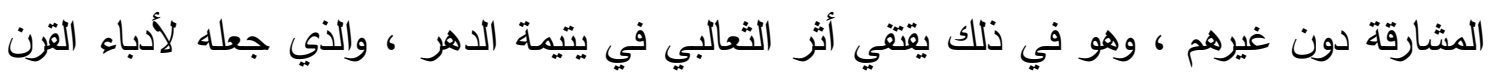

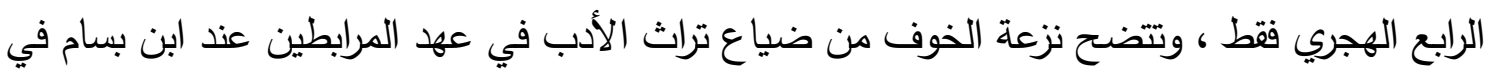

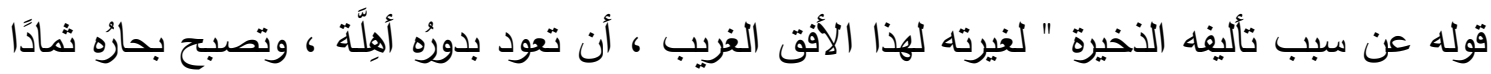

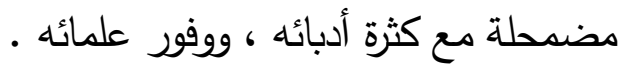
لذا أخذت نفسي بجمع ما وجدت من حسنات دهري وتتبع محاسن أهل بلدتي وعصري ... (r) " . .

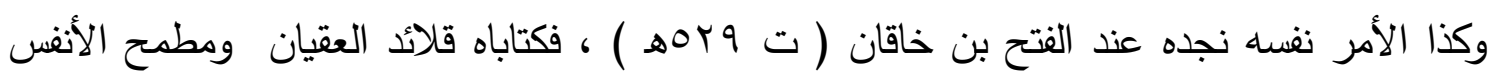

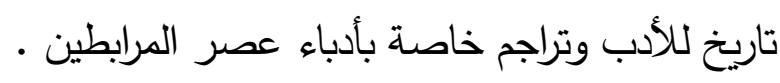

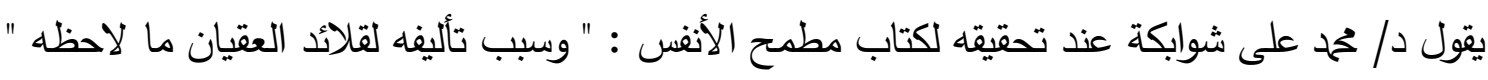

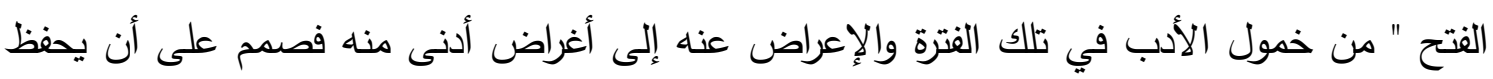

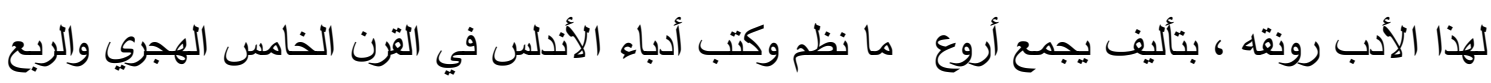

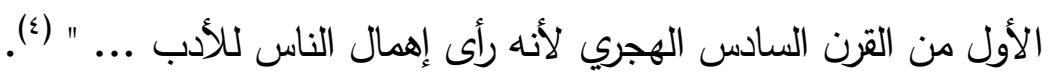

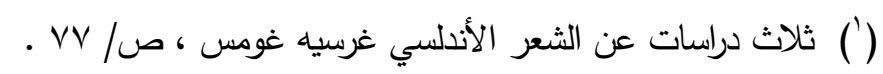

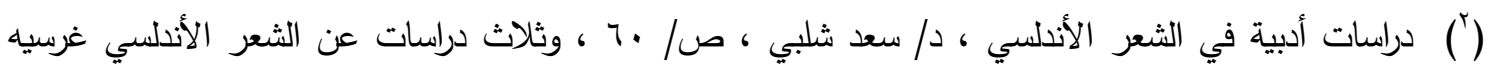

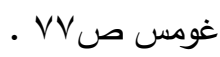

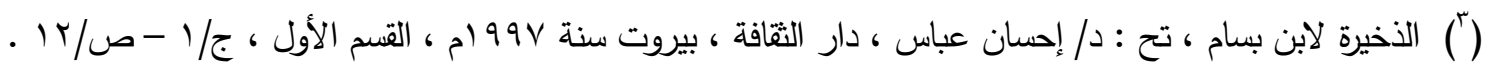

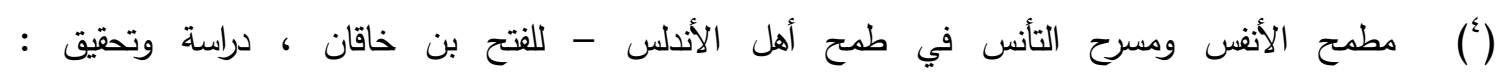

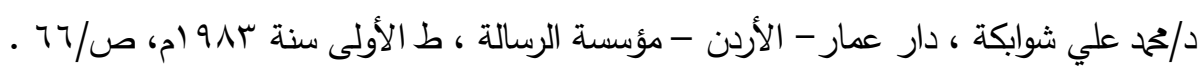




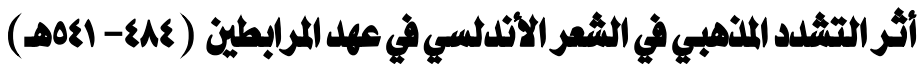

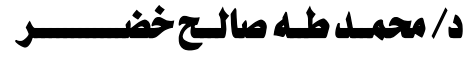

ويؤكد الفتح نفسه ذلك في مقدمة كتابه القلائد قائلاً عن سبب تأليفه : " ولما رأيت عِنَانُه - يعني الأدب

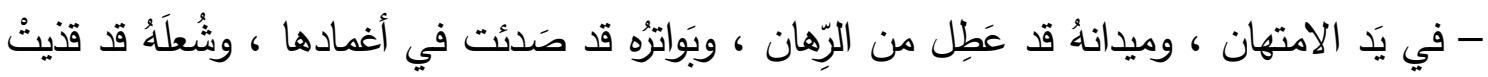

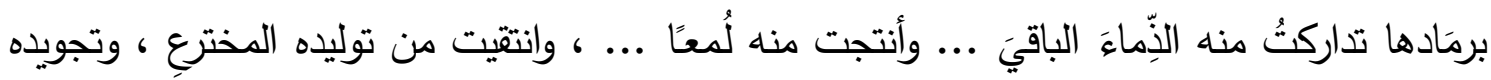

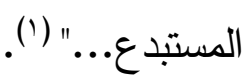
وفي المطمح نجده يؤكد ما سبق قائلاً عن سبب تأليفه : " إنه كان بالأندلس أعلام ، فُتتوا بسحر

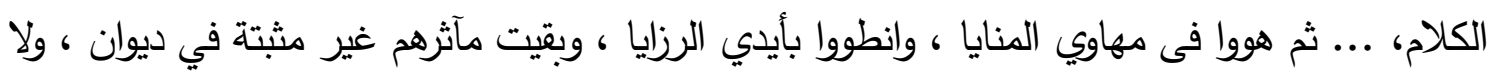

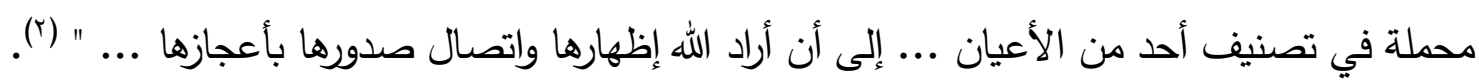

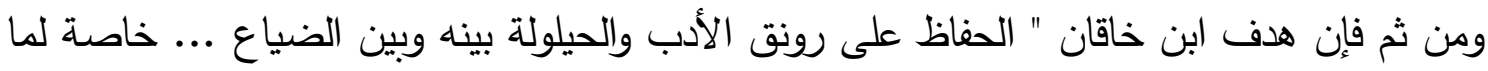

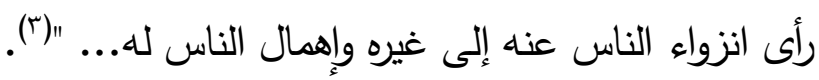

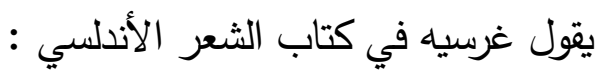

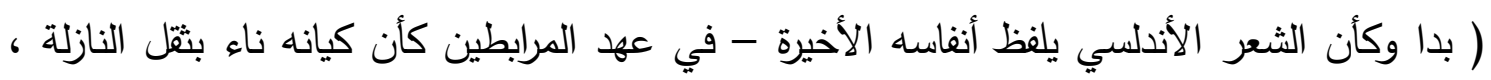

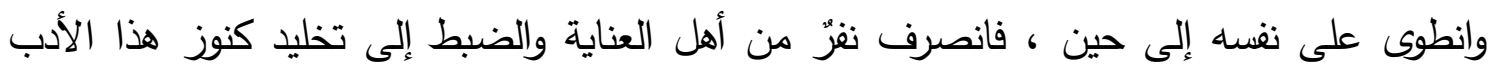

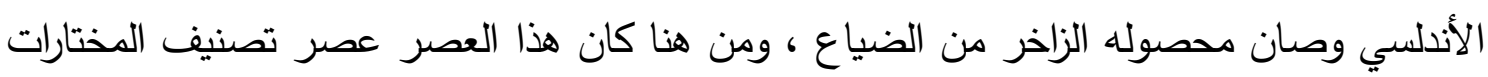

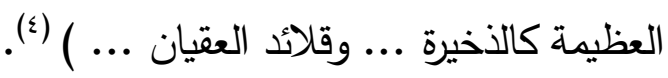

(') قلائد العقيان ومحاسن الأعيان ، لابن خاقان ، تح : د/ حسن يوسف خريوس ، مكتبة المنار ، الأردن ، ط الأولى

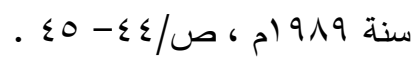

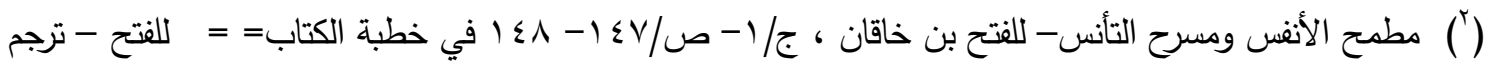
ابن خاقان في قلائد العقيان لأربعة وستين أديبًا عاشوا في القرن الخامس والربع الربع الأول من القرن السادس الهجري بالأندلس وقد ألف المطمح ليكون استكمالًا واستدرًاكًا لمن غفل عن ذكرهم في القلائد للتفصيل المطمح ، ص///11 وما بعدها

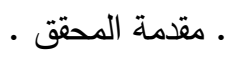

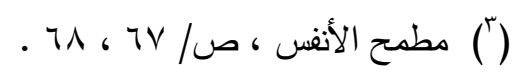

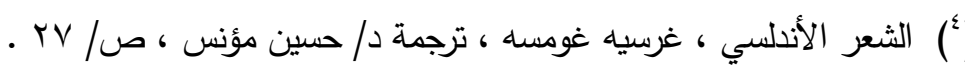

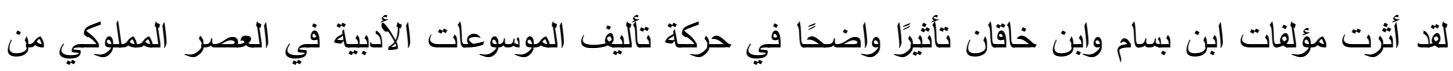

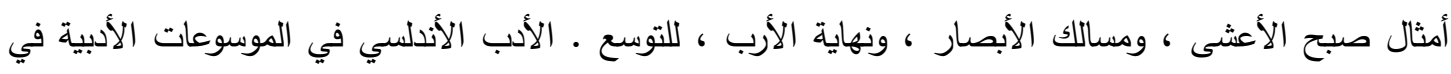

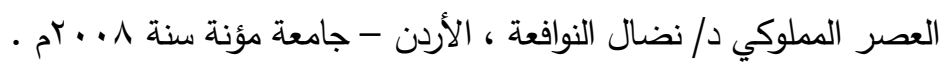


المبحث الثالث

أثر التثدد المذهبي في الأغراض الثعرية وإلعاطفة في عصر المرابطين

مدخل : -

إن عملية التلقي للأغراض الثعرية في عصر المرابطين مع تثدد الفقهاء وعجمة الحكام لتؤكد ما

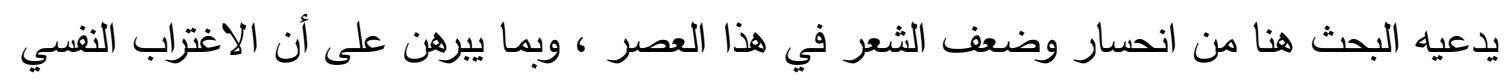

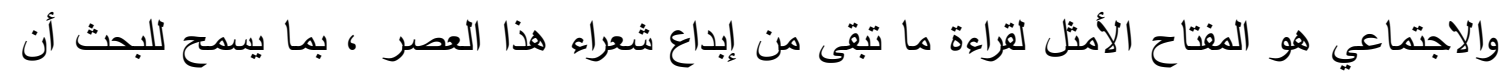

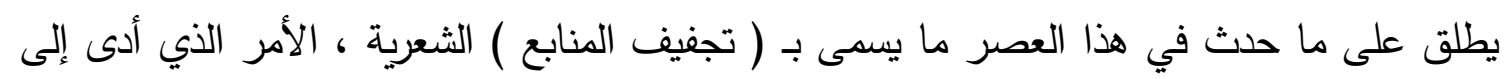

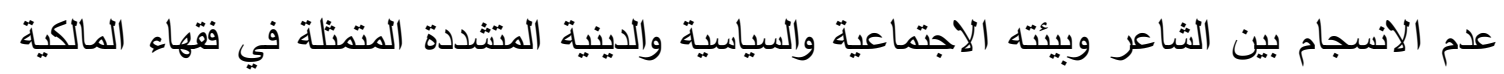
والتي أفتت بأن " الثعر داع لسوء الأدب ، وفساد المنقلب ... ، ويحمل الثاعر على الغلو في الدين

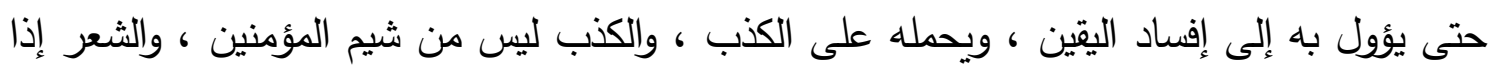

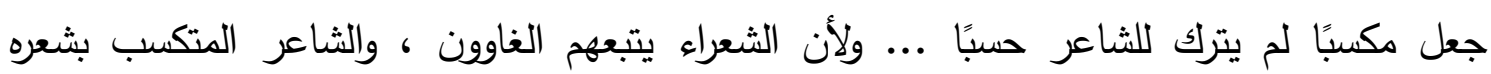
كالكلب، ومن معايب الثعر الوزن والقافية التي تدعو للطرب والغناء ، والثثعراء لا يكتبون في بداية قصائدهم - بسم الله الرحمن الرحيم - تتزيها للشعر عن البسملة ..." (1).

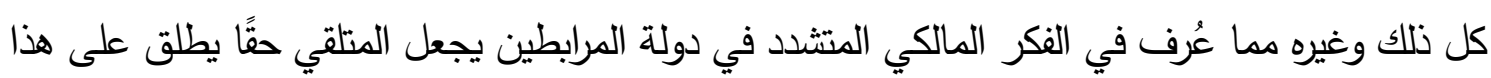
العصر أنه عصر انحسار وضعف للثعر ، وضياع لذكانة الثعراء بسبب هذا الانغلاق والتثدد الديني فلم يكن " دخول برابرة الصحراء الملثمين " والمرابطين " الأندلس ضربة سياعية لهية وضية قاضية للاستقلال

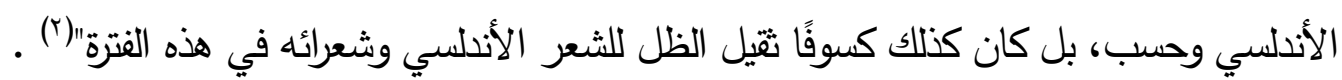

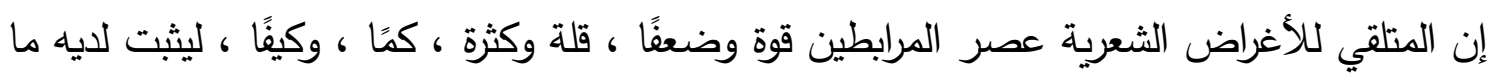

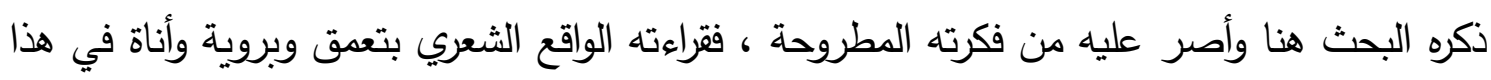
العصر لتؤكد ذلك .

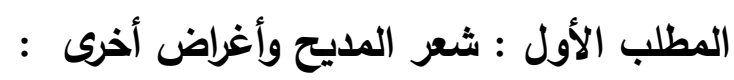

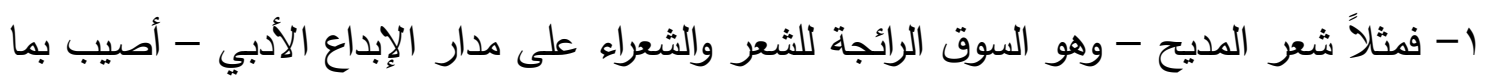

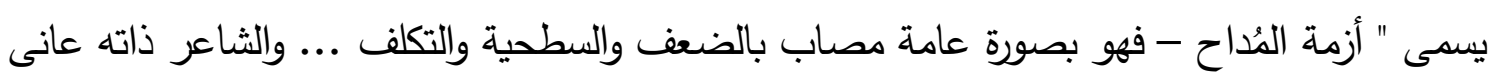

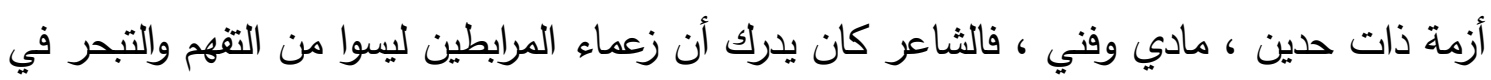

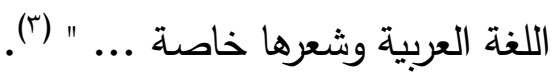

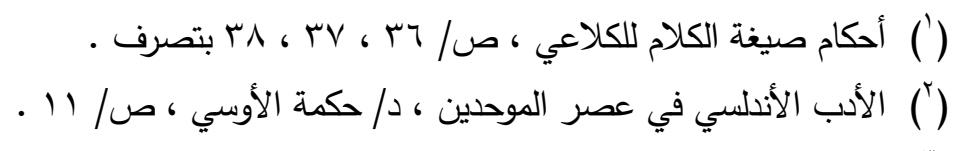

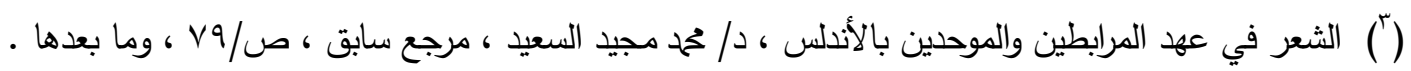




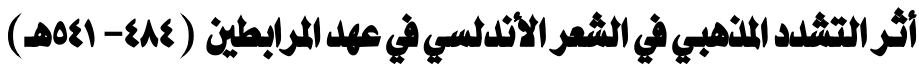

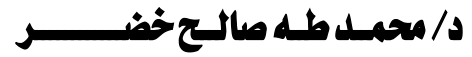

ץ- شعر المجون والخمريات : " أصيب بصدمة عنيفة أيام المرابطين أدت إلى انحساره والحد من تدفقه ، وانصراف الشعراء عن معالجته ... وذلك بسبب الطابع العام لسياسة الدولة من الروح الدينية والأسلوب الزاهد الجاد ... " ('). ץ- شعر الغزل : " فبالمقارنة مع عصر الطوائف وقوته واشتداده من غزل عذري وحسي ... نجد هذه النظرة في دولة المرابطين قد خفت نوعا ما ، واقتصرت على شعراء معينين ... وكان ما تبقى من شعرهم تقليديًا للغاية ، وشعراؤه هم هن أبدعوا في هذا الفن بالأصل في دولة الطوائف ... وكله

مقطعات ... ويغلب عليها الغزل الحسي ... " (r). ع- الثعر الفلسفي بنزعته التأملية : " نجده سطحيًا وضئيلً وقليلًا جدًا..."()؛ لأن الفلاسفة في الأصل كانوا عرضة للاضطهاد والقتل ، ولم يكن ثمة وجه للثقافة الإسلامية إلا فقه المالكية وفقط ( فلم يهتم سلاطين المرابطين بالعلوم والفنون والآداب ، بل عمدوا إلى محاربة كل ما شجعه ملوك الطوائف ، فطاردوا العلوم والفلسفة الكلامية وجرموا هذه الكتب وأحرقوها علنا ... " (؛). ه- شعر الثكوى : يكثر شعر الثكوى من الغربة المكانية عند الثعراء المرابطين ليجعلنا نشعر بعمق عقدة الازدواجية النفسية عند الثاعر بين حبه للمكان الأم وحنينه إليه ، وكراهيته الباطنة لمكانه الجديد لأنه انتقال من مكان مألوف محبب للنفس إلى مكان معاد لا يجد فيه الثاعر نفسه ولا إبداعه ، مما تولد عنه إبداع مزدوج مخلخل الرؤية فما اعتقد - وذلك أمر بديهي إذا ما ثبت أن قلق الثاعر واغترابه عن الواقع لا يكون إلا عندما يشعر بأن قيمته الذاتية لم تعد متوافقة وقيم المجتمع ، هنا يصبح الاغتراب همًا يختفي وراء حلم الثاعر ... مما يجعل الثاعر يعيش في حالة مضطربة وقاتمة في عالمه الداخلي من الاحتماء والانتماء ، القبول والرفض (0).

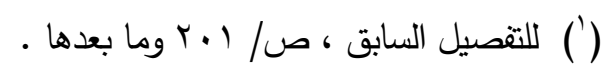

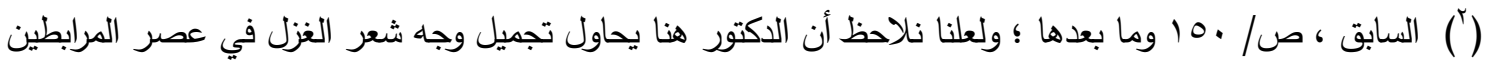

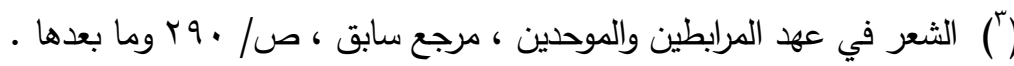

$$
\begin{aligned}
& \text { (2) السابق نفسه . }
\end{aligned}
$$

( ) للتفصيل : الاغتراب في الثعر العربي في القرن السابع الهجري ، دراسة اجتماعية نفية د/ أحمد الفلاحي ، دار

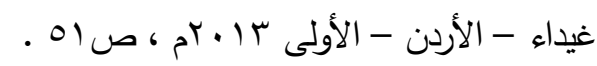




\section{المطلب الثانسي \\ كثرة هجاء الحكام ورجال الدوبـــة}

لما أيقن الثاعر بغربته في عصر المرابطين ، وثبت في خلده أن هؤلاء المرابطين البربر هم أعداء

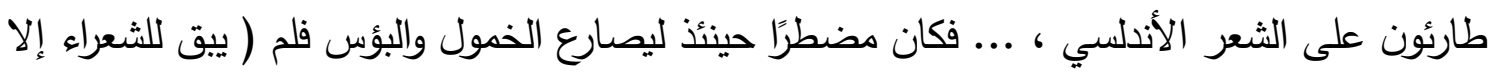
عزاء واحد هو أنهح كانوا يستطيعون أن يُعرضوا بالحكام وينشئوا القصائد الهجائية المليئة بالمرارة يهجون بها أولئك الفقهاء المنافقين (') وقد تتوع هذا الهجاء بين هجاء المرابطين وهم رجال الدولة ، وهجاء الفقهاء والوزراء ، ومن دار في

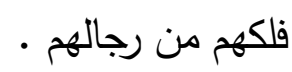
ومن أبرز هؤلاء الثعراء الهجايون في عصر المرابطين نجد أبا بكر يحيى بن سهل اليكّي ، وابن صارة

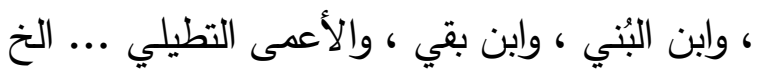

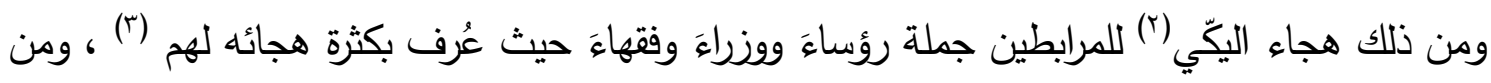

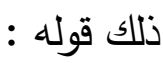

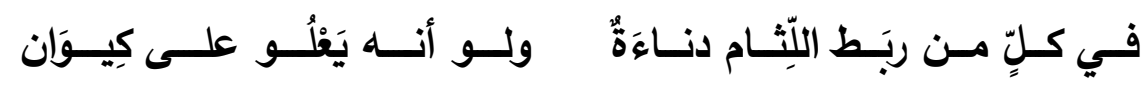

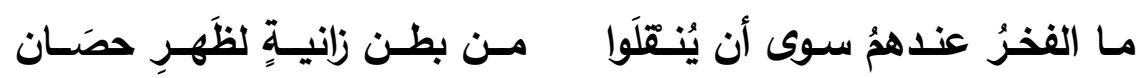
وضـعوا القـرونَ مواضـع التيجـان المنتمـــــون لحِمْيَـــــر لكـــنَّهْ واطلبْ شُعـاعَ النـار في الغُدْرَانِ

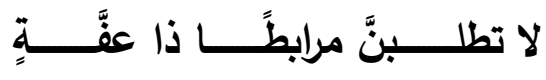

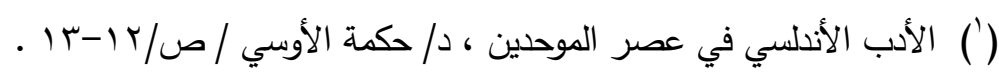

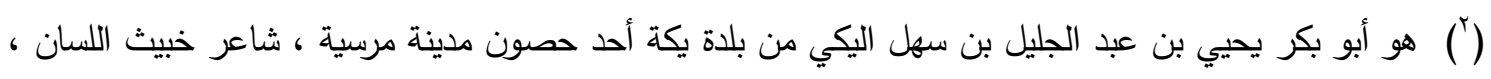

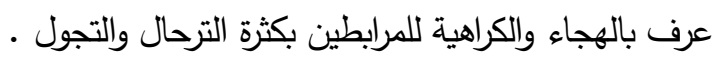

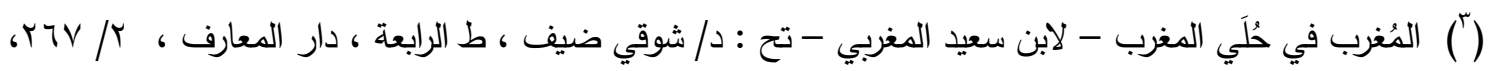

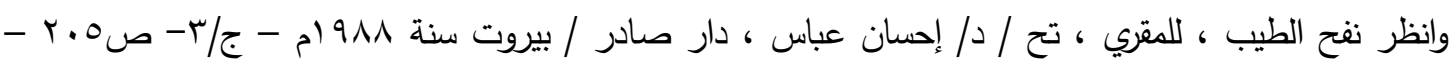




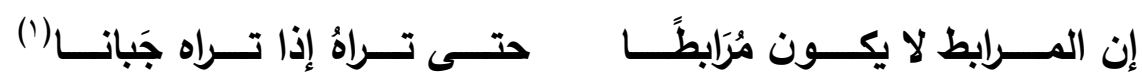

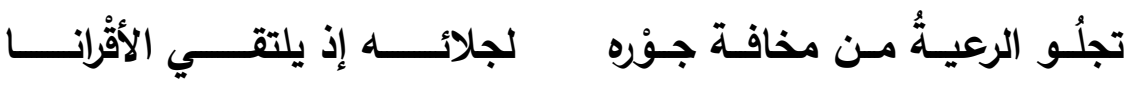

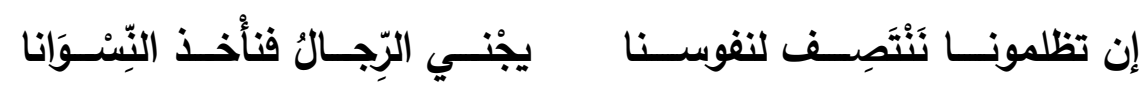

ولكثرة هجائه في رجال عصره قال عنه ابن سعيد : ( هو ابن رومي عصرنا ، وحطيئة دهرنا لا تجيد

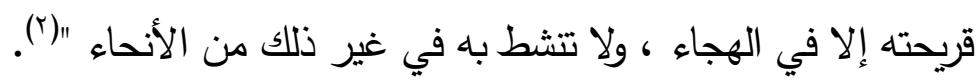

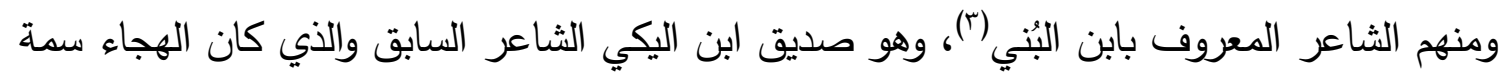

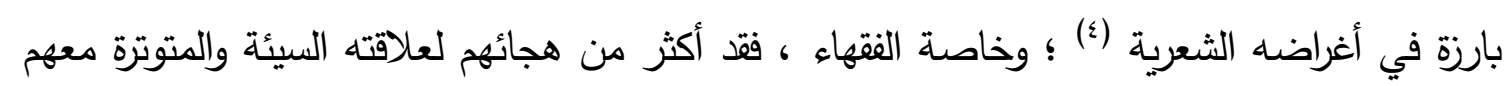

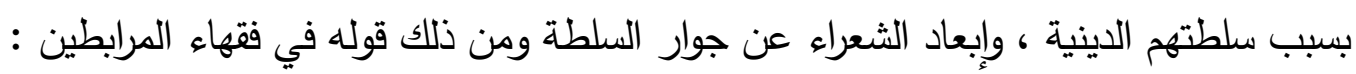

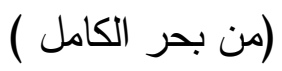

أهل الرياء لبستموا ناموسكم كالذئب أدلج في الظلام العاتم فملكتموا الدنيا بذهب مالك وقسمتموا الأموال بابن القاسم

وركبتموا شهب الدواب بأشهب وبأصبغ صيفت لكم في العالم(0)

( من بحر الكامل ) وقوله عنهم بعد الثناء على الإمام مالك :

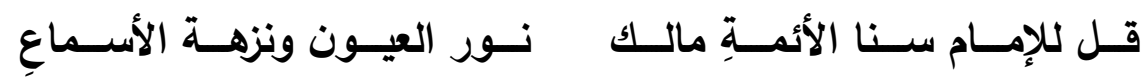

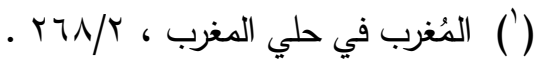

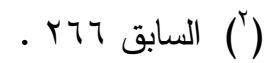

(") هو أحمد بن الحسن بن شقير ، وكنيته أبو جعفر ، عربي صليبة دخل أسلافه الأندلس في فترة ربما هي فترة الفتح

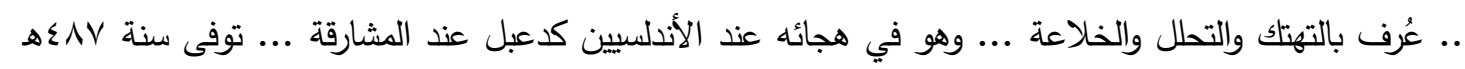

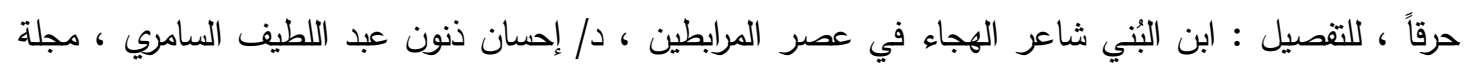

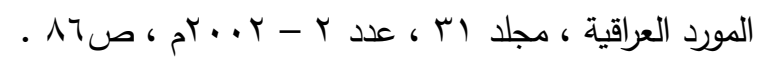

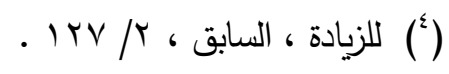

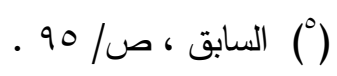




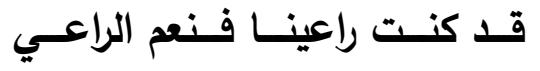

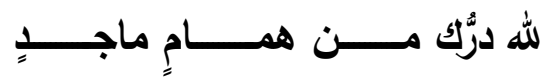

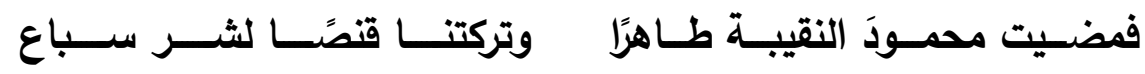

أكلــوا بـك الــنيا وأنــت بمعـزلٍ طـاوى الحشــا متكتف الأضـلاع

تثـكوك دنيـا لــم تـزل بـك بـرةً مــاذا رفعت بها مـن الأوضـاع|(')

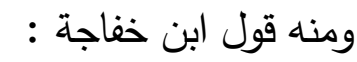

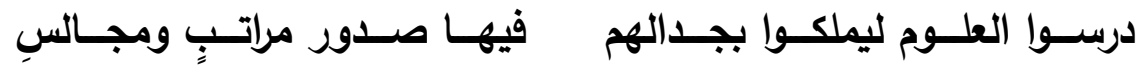

وتزهّــدوا حتــى أصــابوا فرصــةً في أخذ مـال مسـاجٍٍ وكنـائس(؟)

هذا وقد كان للنثر الفني نصيبه من هجاء المرابطين ورجال الدولة فكما كان الهجاء في الثعر كان

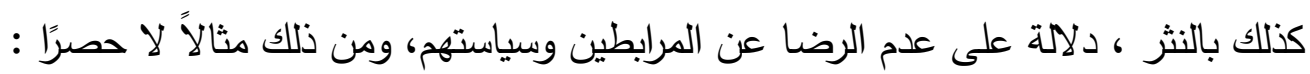
- رسالة ابن أبي الخصال (ז) وقد ( أفحش فيها على المرابطين ، وأغلظ لهم في القول أكثر من الحاجة

- رسالة الثقندي والتي يسخر فيها من عدم فهم قائد دولة المرابطين للشعر ومعانيه (०) ويتهمه بجفاء

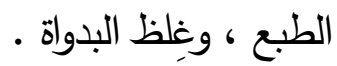

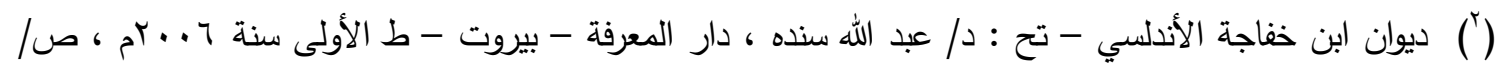

(") المعجب في تلخيص أخبار المغرب ، عبد الواحد المراكثي ، شرحه وحققه د/ صلاح الدين الهواري ، المكتبة

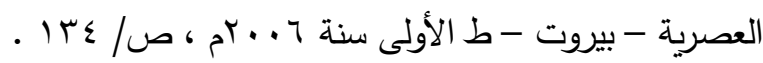

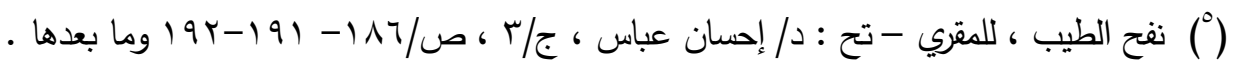




\section{المطلب الثالث}

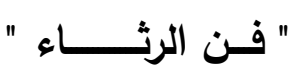

وكثر الرثاء بأنواعه في عصر المرابطين ( فقد توسع فن الرثاء ) في هذا العصر من رثاء النفس ، أو من الرثاء الاجتماعي ، للأحباب ، والأصدقاء ، والزوجات وحتى الدواب والكلاب ، والأثاث ('). أو رثاء المدن وسقوطها سواء على أيدي النصارى ، أو على يد المرابطين أنفهه ، وما أظن هذه الاه الكثرة في شعر الرثاء إلا عملية استبدال وتعويض لضعف الثعر فيما سبق ذكره ، فوجد الثعراء هنا

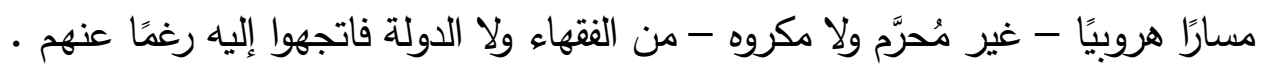
ويجب لفت الأنظار إلى أمر نقدي مهم للغاية ، بخصوص شعر الرثاء ألا وهو أن المرابطين أنفسهم

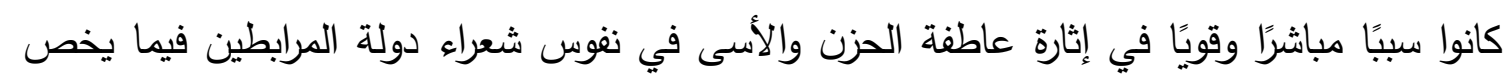
(رثاء الممالك الزائلة ( عندما دخلوا إلى بلاد الأندلس واحتلوا إمارات ملوك الطوائف بفتوى من فقهاء المالكية .

فنجم عن ذلك شعرٌ كثيرٌ في رثاء ممالك الطوائف الزائلة ، ورثاء الأمراء الذين زالت دولتهم وسلبت عروشهم على يد المرابطين البربر (؟). فقد أفتى فقهاء المالكية يوسف بن تاشفين بخلع ملوك الطوائف فأخذ يقضي عليهم الواحد تلو الآخر حتى قضى عليهم جميعاً ، وصارت الأندلس ولاية مرابطية ... ) (ץ). وقد مثَّل فن الرثاء على يد شعراء من مخضرمي الدولتين دولة الطوائف ودولة المرابطين نتاجًا عزيزًا وصادقًا يحن بصدق لدولة الطوائف ويبغض المرابطين ؛ لأن دولة السابقين هي دولة الثعر والثعراء ببلاطاتها المختلفة والمتعددة ، وقد مثل ذلك مادة علمية قامت عليها دراسة جادة وفي بابها جاءت : تحت عنوان

رثاء ملوك الطوائف وممالكهم التي سقطت على يد يوسف بن تاشفين ( (؛).

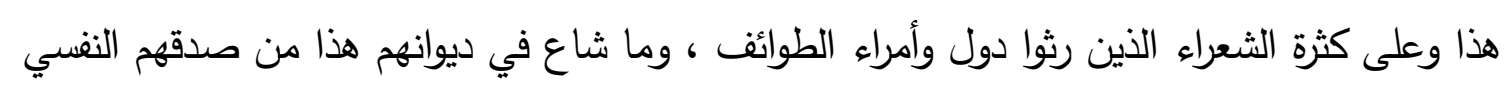

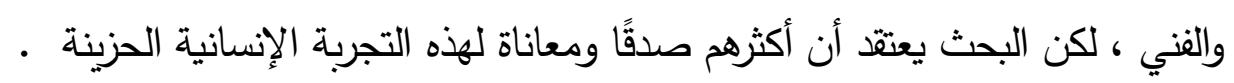

(') اللتقيل : الرثاء في الأندلس عصر ملوك الطوائف د/ فدوى عبد الرحيم قاسم ، فلسطين ، سنة م ...rم ، صل م م ، وما بعدها

(') المعجب في تلخيص أخبار المغرب ، لابن عذارى المراكثي ، تقديم وتحقيق د/ حمح عرب ، دار الفرجاني ، بدون ، ص ص r מ

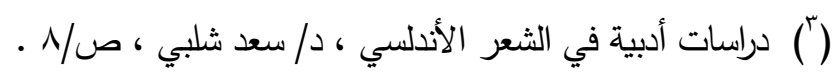

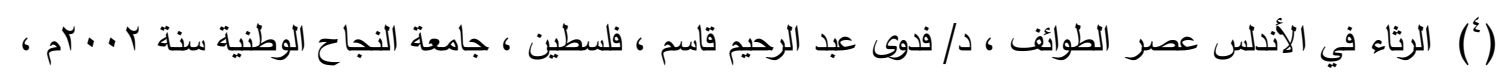

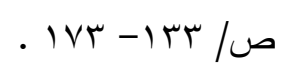


1- ابن اللبانة الداني (ت V • مهـ ) في رثاء إثبيلية وأميرها المعتمد بن عباد بعد سقوط دولته على يد

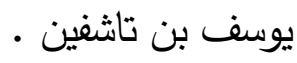

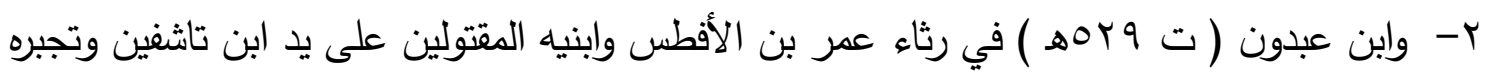

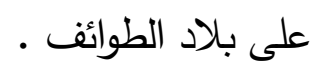

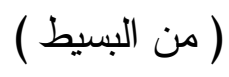

على البهالئل مِن أَبْنَاء عَبَّادِ وكانتِ الأرضُ منهم ذَاتَّ أوْْتَادِ

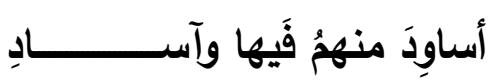

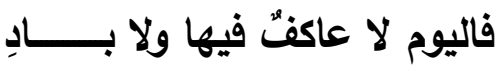

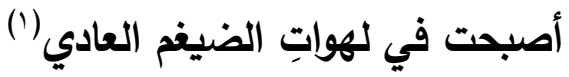

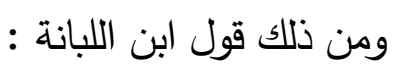
تبكي السَّماءُ بلمع رائح غائه

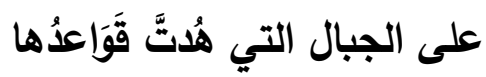

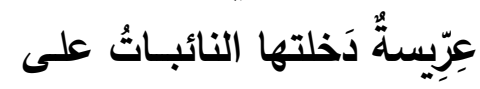

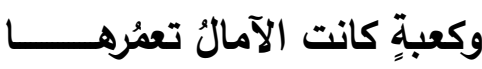
ألقي السّلاح وخل المشرفي فقد

ولو رحنا نستعرض العاطفة عند ابن اللبانة في شعره الغزير في رثاء دولة بني عباد فنجد أن كل فئل

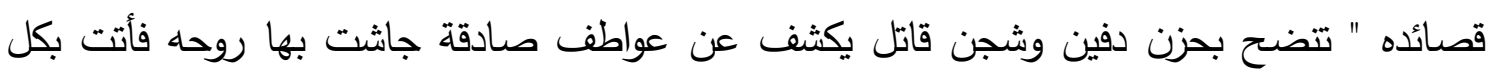
حزينِ وبالكٍ " (r) ومن قصيدة ابن عبدون الأنللسي(") في رثاء ابن الأفطس ودولته ( من البسيط ) :

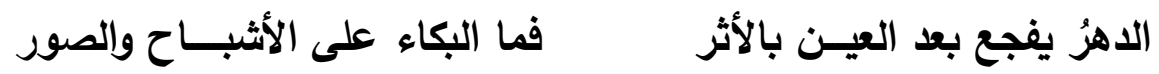

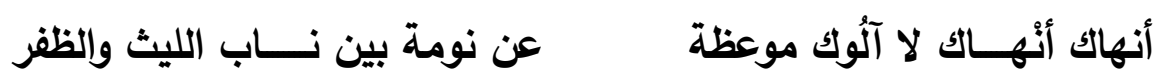

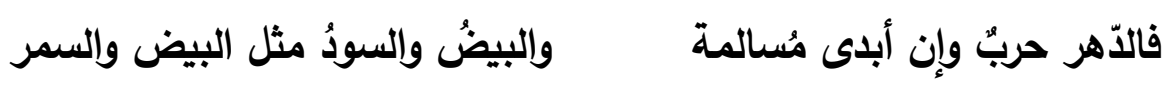

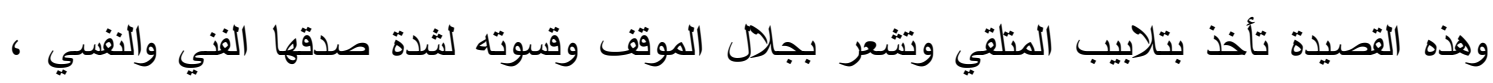
وتعكس صورة البربر الغليظة في حكمه للأندلس زمن المرابطين .

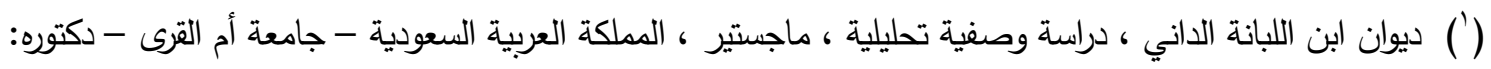

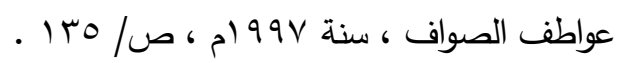

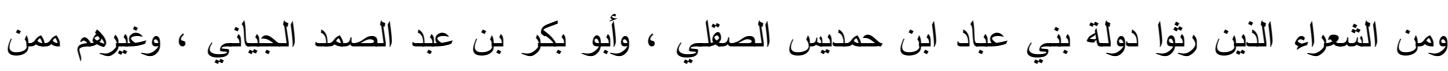
عاصروا هذه الفترة .

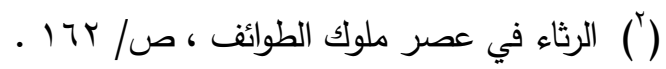

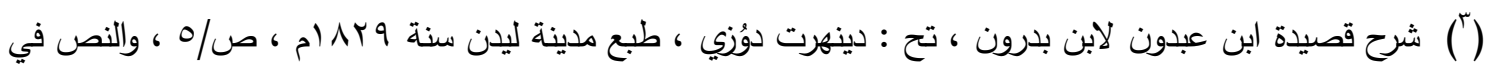

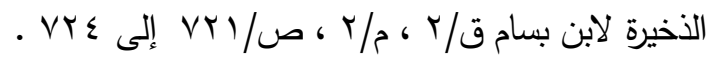




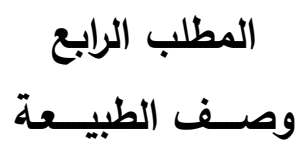

وأمَّـا وصف الطبيعة : فمن أوسع أبواب الثعر غزارة في عهر المرابطين ، فقد كثرت القصائد الطوال

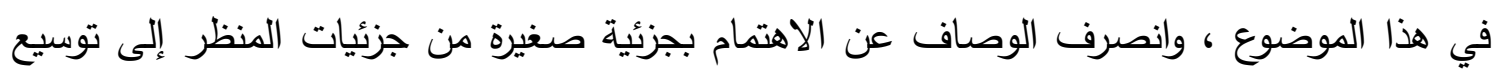

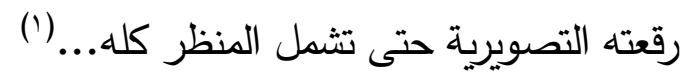
وهذا واقع لا مرية فيه ، ويُعد مزية تميز بها شعر وصفئ الطبيعة فئهي في عهد المرابطين ، بيد أن التأمل والقراءة الواعية حول هذا الغرض تضع أيدينا على حقائق نقدية مهمة ، منها التالي :

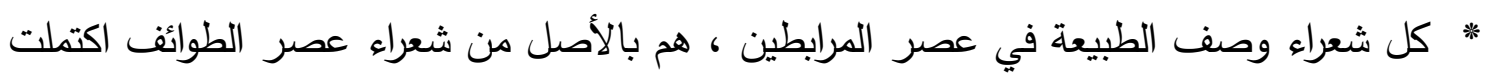

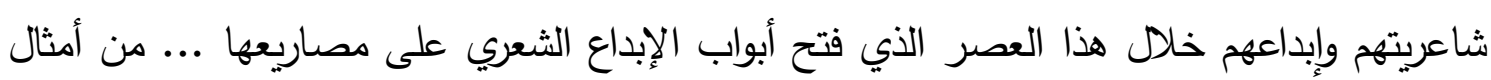
ابن خفاجة ، وابن صارة الثنتريني ، وابن الزقاق ، والأعمى التطيلي وغيرهم ل...

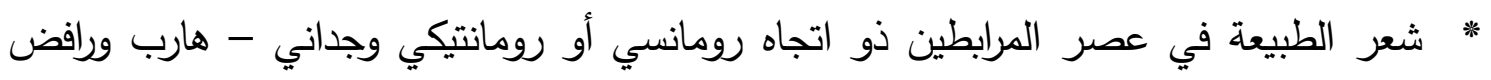

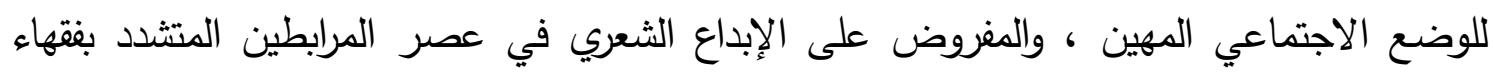

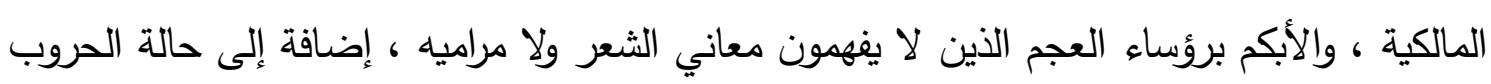

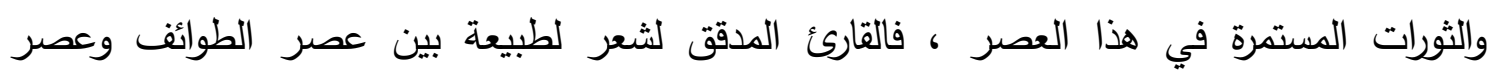

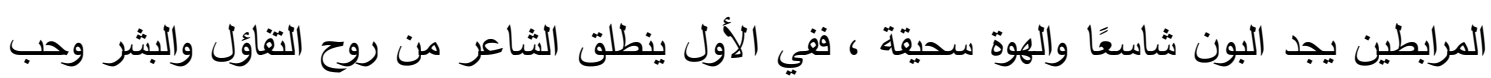

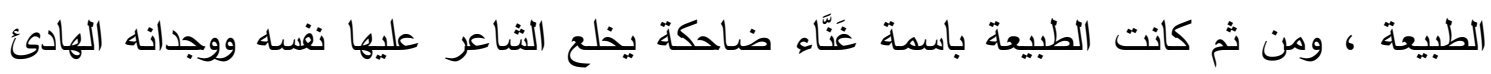

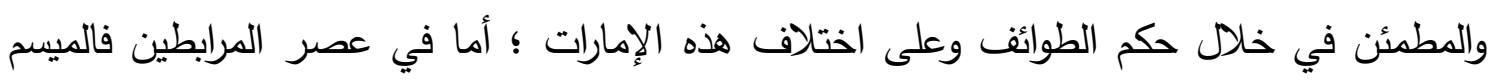

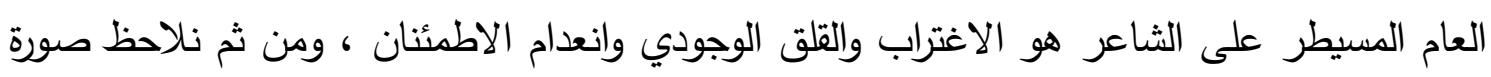

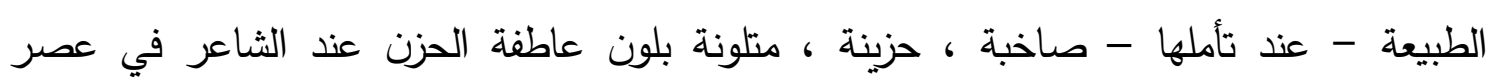

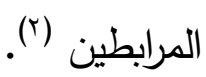

ويكأني بشعر الطبيعة في هذا العصر يمثل نوعًا من التحرر الفكري للثاعر من القيود الدينية

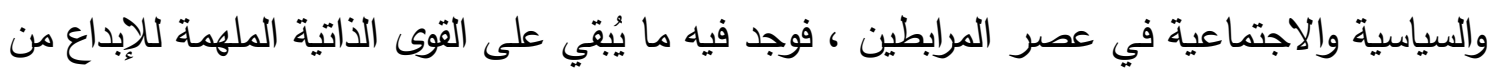

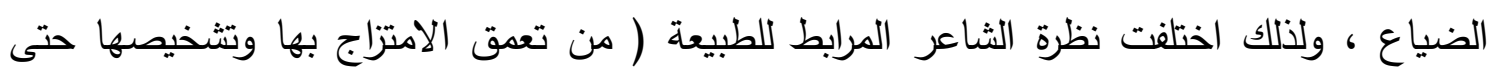

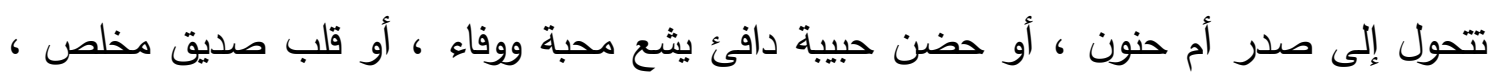

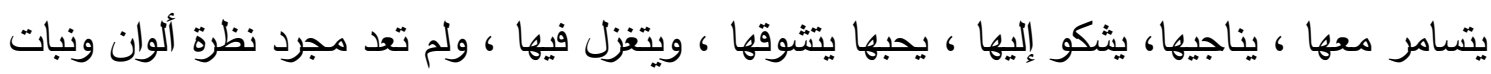

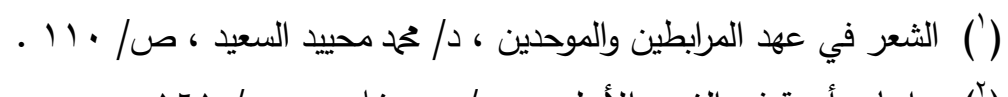

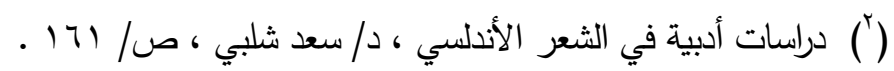


وظواهر بل أخذت بُعدًا آخر ، يحوي عاطفة إنسانية حزينة (').

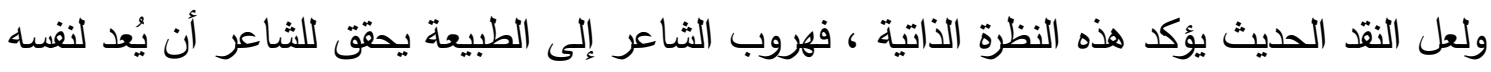
مجالاً أكثر ملائمة لنشوئه وترعرع قواه الذاتية (؟).

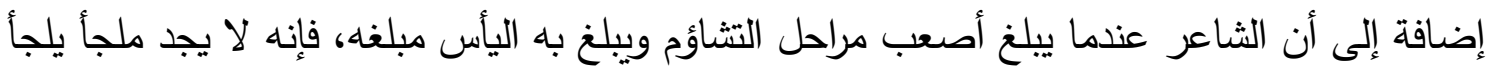

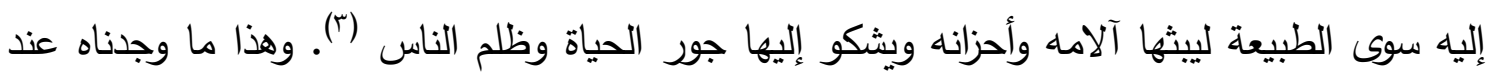

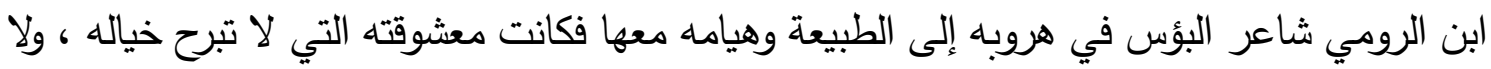
تتأى عن ناظريه ويستكين في أحضانها ساعة البأساء إذ تزحمه الهموم .... "(\{).

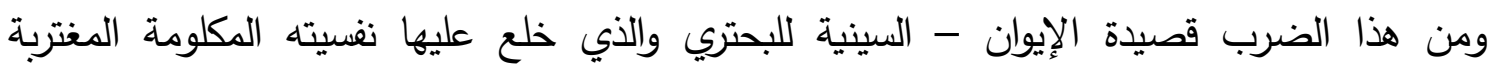
القلقة (०). وفي الحديث نجد الكثير من شعراء المهر وغيرهم ممن تغنوا بجمال الطبيعة ، وتماهوا معها لأنها كانت كانت سبيلهم للهروب من الظلم والعقبات الاجتماعية والغربة النفسية " .

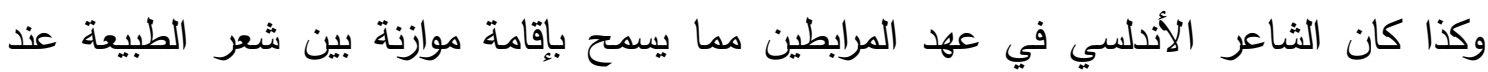

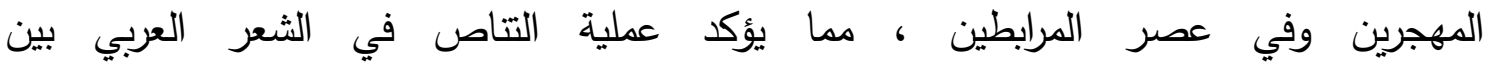

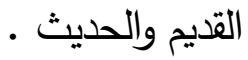
قلت ، وليس أدل على ما ندعيه هنا من شعر الطبيعة تحديدًا عند ابن خفاجة الثاعر المبدع خلال

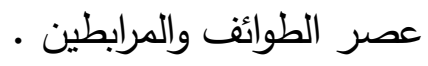
فثعر الطبيعة عنده في عهده الأول في دولة الطوائف يغلب عليه " وصف الطبيعة الضاحكة ...

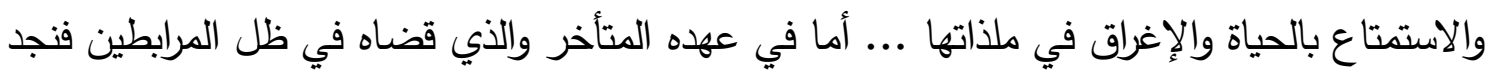

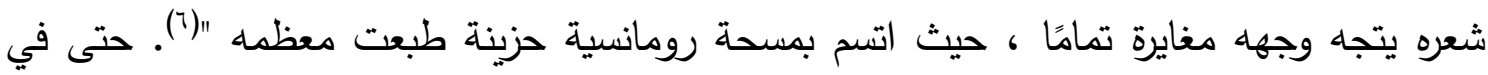

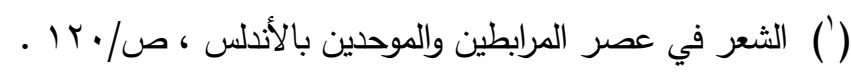

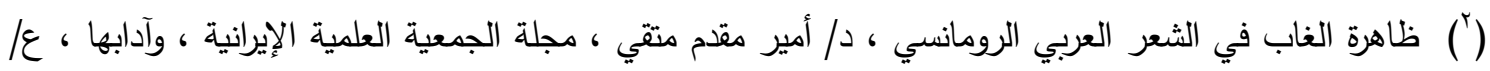

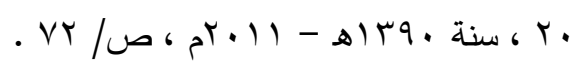

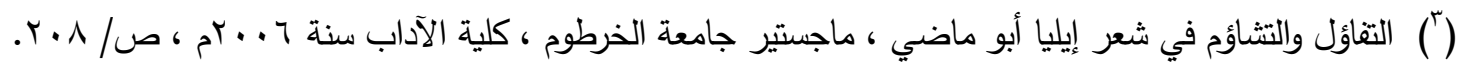

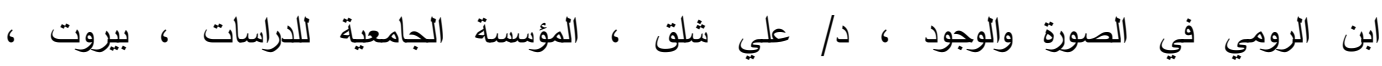

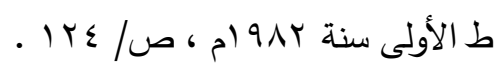

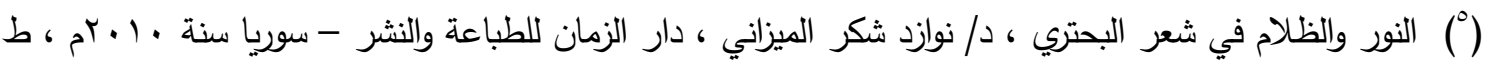

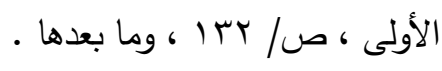

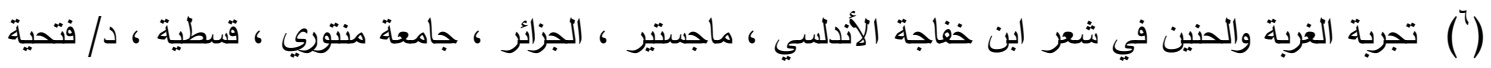

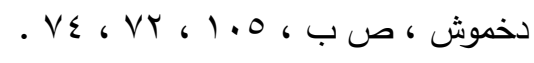




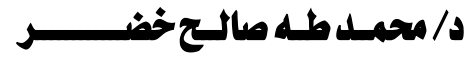

قصائده المدحية في ظل المرابطين فسرعان ما تتحول إلى قصائد غربة وحنين وكثيرًا ما يتردد فيها الثكوى والحسرة واجترار آلام للحاضر بتذكر آمال الماضي ... ومن ثم تحول شعر الطبيعة عند ابن فئن خفاجة بين العهدين أيام الطوائف والمرابطين " فأصبحت الطبيعة ومظاهر الكون كئية مظلمة كذاته

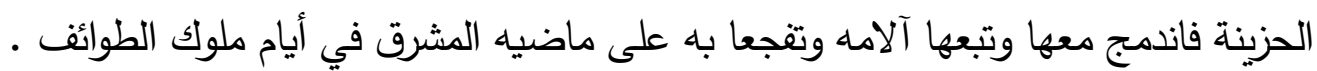

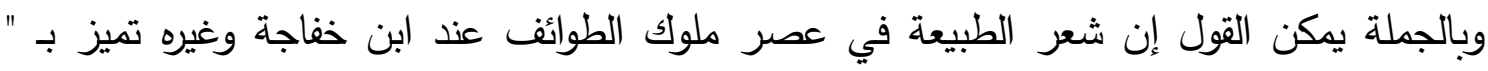

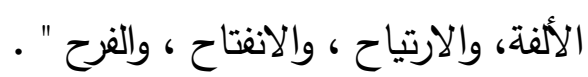

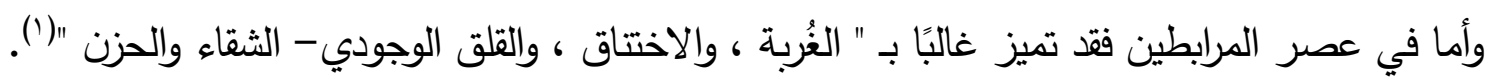

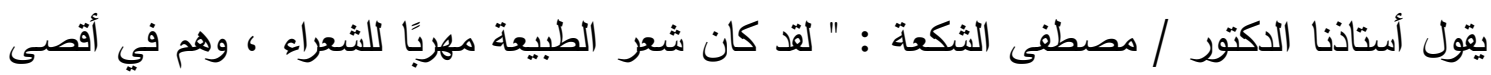

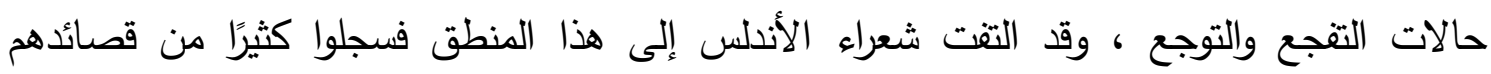

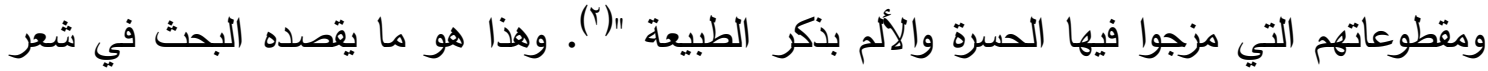
الطبيعة في عهد المرابطين - وخاصة شاعرهم الأكبر في وصف الطبيعة ابن خفاجة " فهو قمة شعراء الطبيعة في الأندلس كلها وخاصة في عهد الطوائف والمرابطين " (؟).

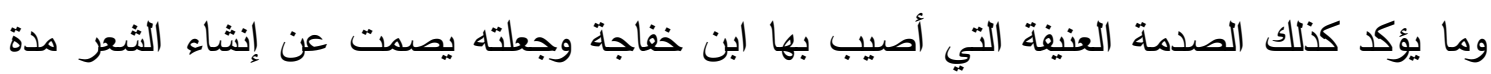
اضطراب شبه الجزيرة في أوائل عهد الررابطين ، والذين كانوا أعداء حقيقيين للثعر والثعراء ، قصيدته

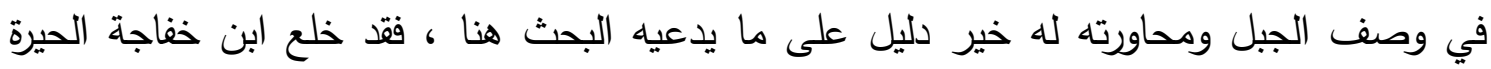
والحسرة والضعف والحزن النفسي وأسقطها على الجبل كأنسنة للطبيعة وتماهى معها هروبًا من واقعه . " ولذلك كان ابن خفاجة شاعر الطبيعة الأولى بين عصر الطوائف والمرابطين يرى الطبيعة في إطار

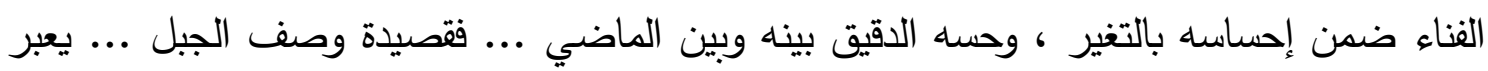

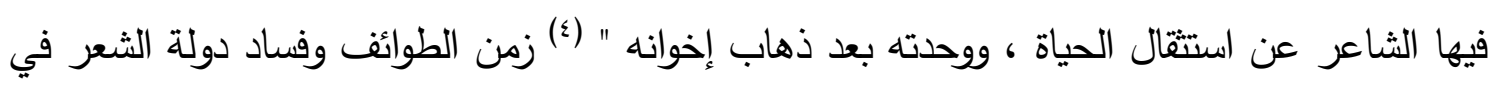

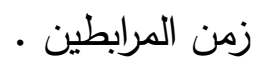

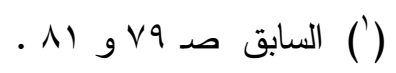

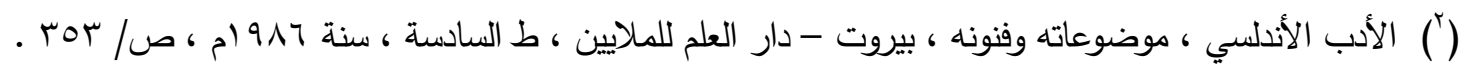

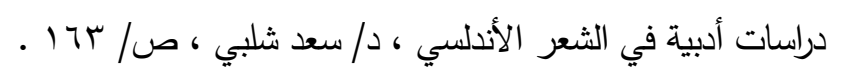

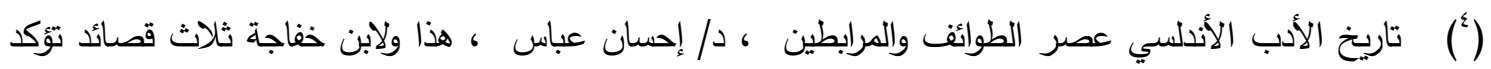

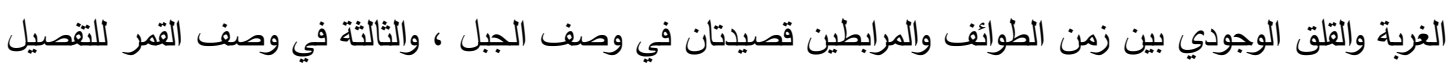




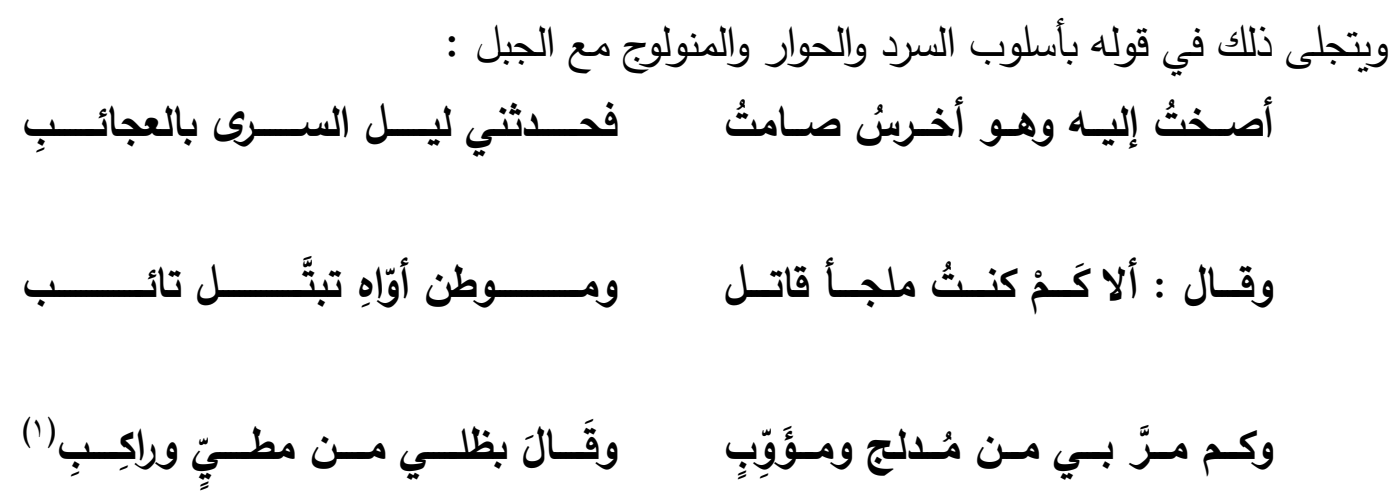

إلى آخر النص مما يتطلب قراءة تأويلية تتفق والتلقي لهذا النص المراوغ من شاعر يشتكي الغربة الفنية

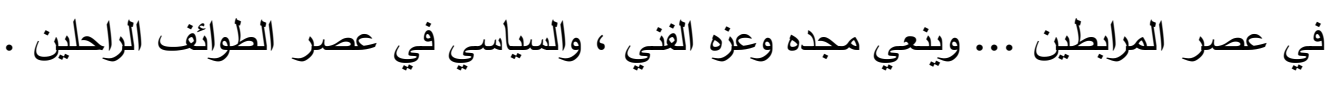




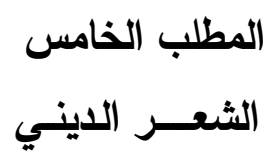

كثر الثعر الديني من الزهديات ، والنبويات وغيره في عصر المرابطين - كثرة مفرطة ... ولكنها كثرة

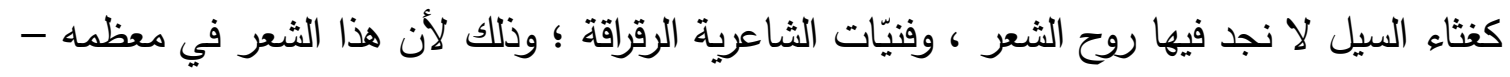

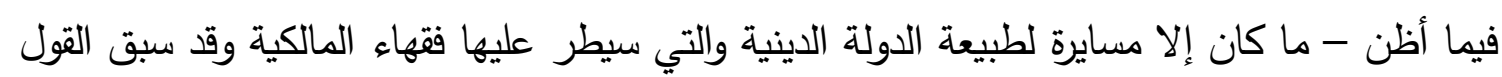

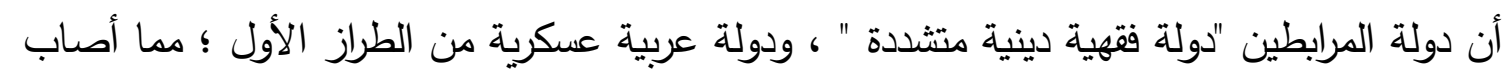

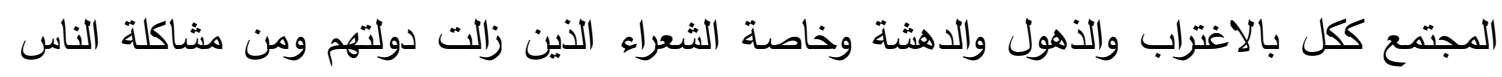

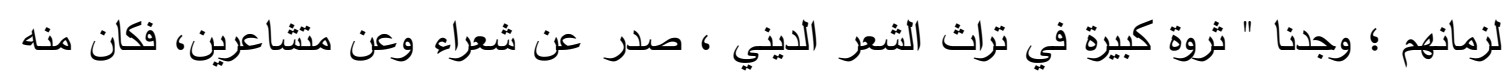

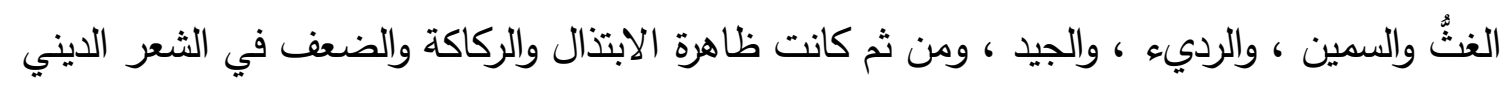

$$
\text { واضحة بينة " ('). }
$$

ناهيك عن المقصد النفعي البعيد عن العاطفة الثعرية الخالية من صدق التجربة في هذا الثعر "

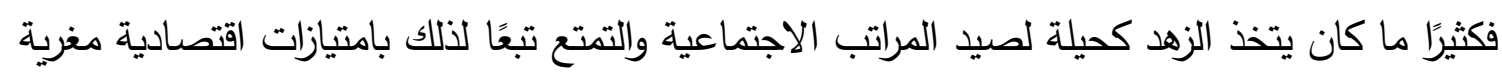
، ولا سيما إذا كانت السياسة العامة للدولة مشجعة على هذا التيار الزهدي " (؟).

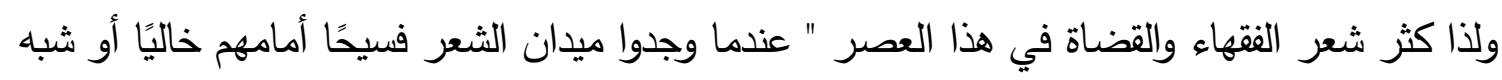
خال من الفحول ، فكثر بينهم الثعراء وذلك كان أمرًا طبيعيًا بسبب تأخر طبقة الثعراء الحقيقيين

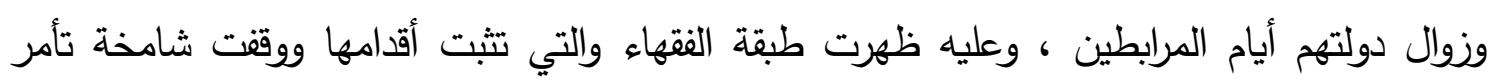

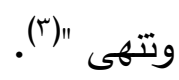
وبالجملة يمكن القول إن شعر هؤلاء إنما هو من شعر العلماء الذي يغلب عليه الطبيعة النثرية ، ويخلو

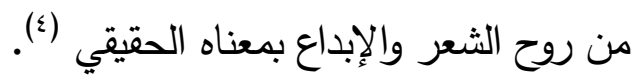

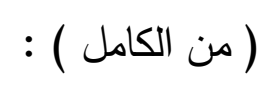

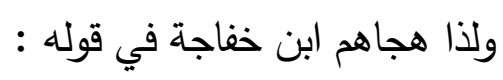

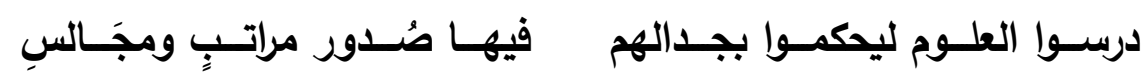

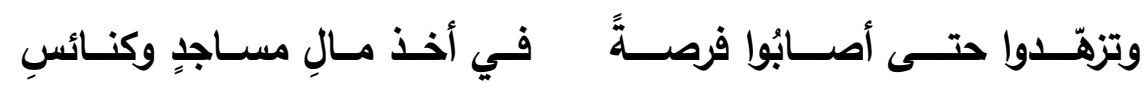

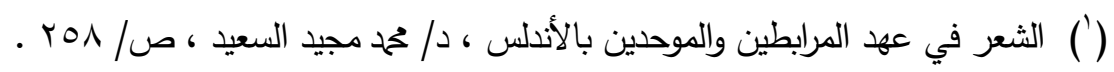

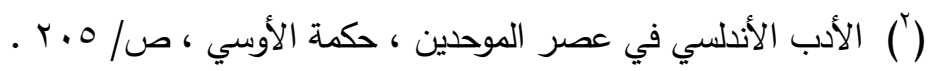

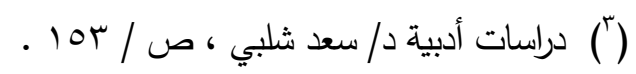

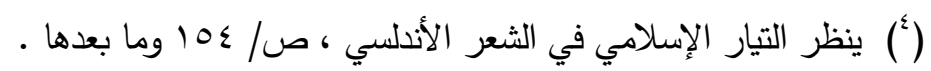


يقول د/ منجد مصطفى (') " إن نشاط الأدب بدأ يخف شينًا فثينًا في عصر المرابطين فأصابه الخمول والضمور ... فأدبرت دولة الشعر في ظلهم ولم يكن له النصيب الذي أحرزته في ظل ملوك

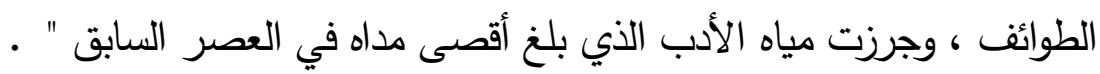

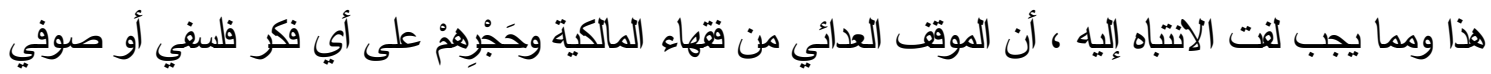
يحاول أن يهام دولتهم وكيانهم اليني المتثدد ، حرم الثعر العربي في عهد المرابطين من ( عبقرية الخيال ) في

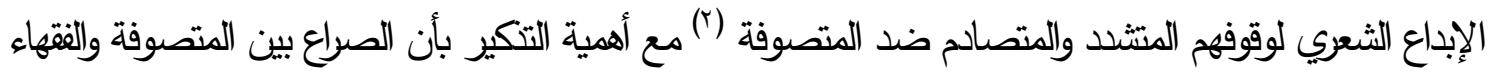

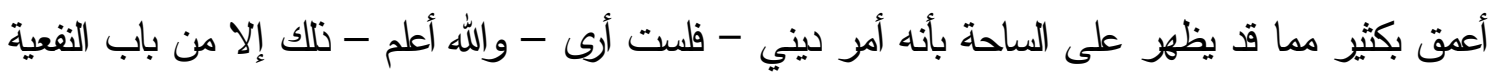
وخوف ذهاب المكانة التي وصل إليها أولئك الفقهاء زمن المرابطين ؛ ولذا لم يتجاوز الأستاذ / حمح عبد الله عنان

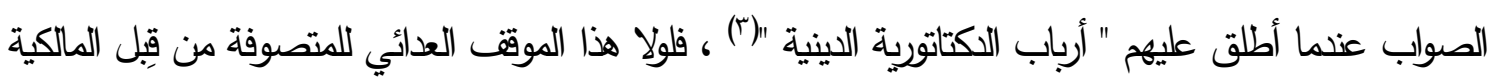
لكان للخيال أثثه في قوة الثعر في عصر المرابطين مما وجنا بعد نلك في أبب ابن عربي ، وأبي الحسن

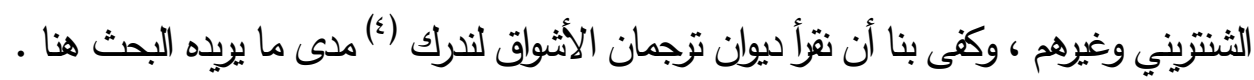

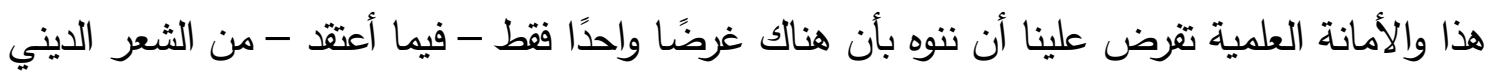
في عهد المرابطين قد تميز بالإبداع المتقن ؛ لأنه صدر عن صنان صدان فئن في العاطفة ومعايشة حقيقية

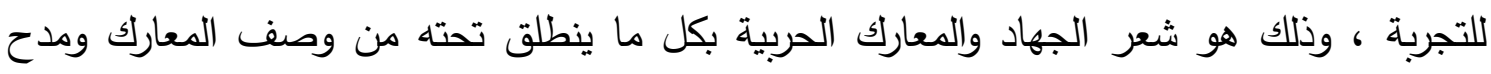

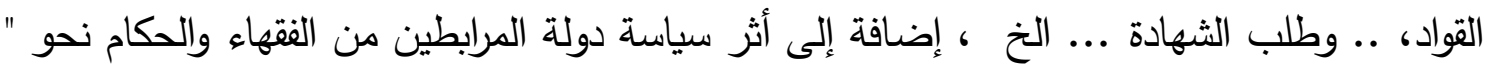
الولع بالحروب والجهاد في سبيل الله ونشر الدين ؛ ومن ثم بدتُ صورة شعر الحرب أكثر إثراقا

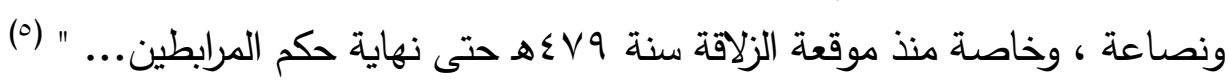
وكما انعكس نلك في الشعر بوضوح انعكس كذلك في النثر الفني أيام المرابطين .

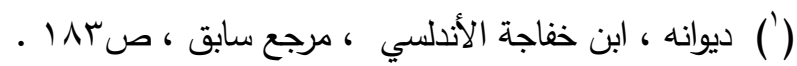

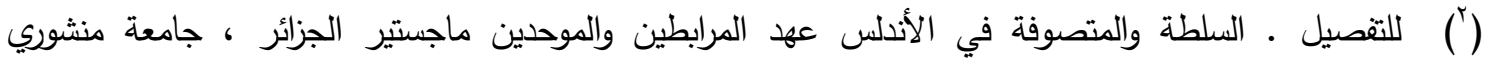

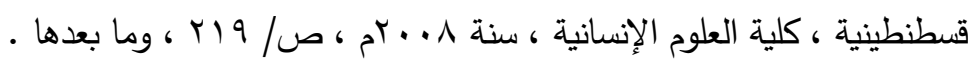

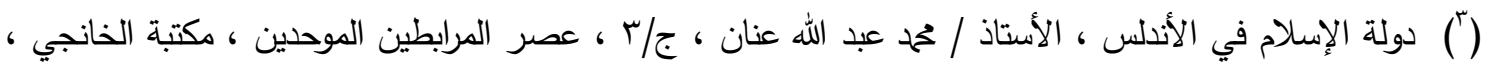

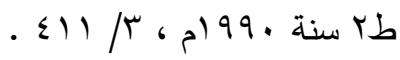

() ألتوسع • بنية اللغة الثعرية في ديوان ترجمان الأشواق ، لابن عربي د / أنور مصطفى أحمد ، سلسلة كتابات نقدية

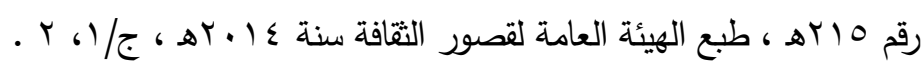

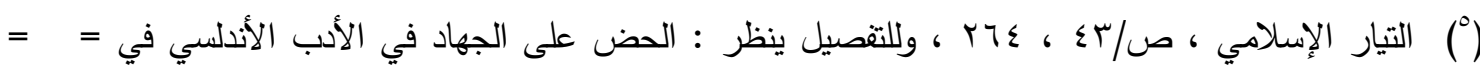

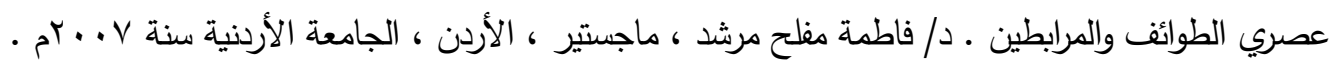

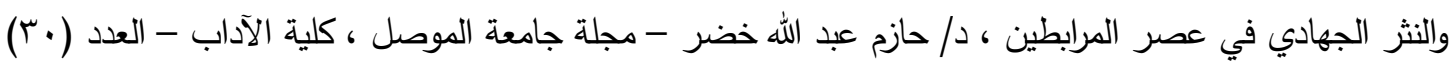

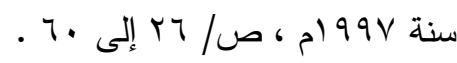




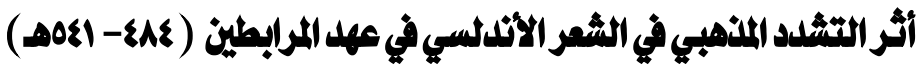

\section{د/ محمـلــه مالـح}

المطاب السادس

العاطفة الشعربية عند شعراء دولة المرابطين

وترتيبًا على ما سبق وإذا ما كان " للعاطفة دورها الفعال في تحديد الأغراض الثعرية وتوجيهها في النقد الأدبي قديمًا وحديثًا (') ، فلثعر دواع تحث البطيء ، وتبعث المتكلف ، منها الطهع ومنها الثوق ، ومنها الثراب ، ومنها الطرب ، ومنها الغضب ، ... فإن البحث ليؤكد هنا نضوب قريحة الثعراء غالبًا من عاطفة الرضا والطرب - فالواقع الاجتماعي والنفسي لحالة الثعراء يؤكد ذلك - وإنما العاطفة التي سيطرت على إبداع هذا العصر بأكمله عاطفة الغضب والحزن والأسى ، وقد ذكرنا سابقًا أن إبداع هؤلاء الثعراء مفتاحه الاغتراب ، والذي يعني الانفصال والانعزال من الثعر عن واقعه الاجتماعي بسبب سطوة الفقهاء وسيطرتهم على مقاليد البلاد ، إضافة إلى وجود رؤساء غلاظ الطبع لا يفهون الشعر، ولا يتذوقونه مما يؤكد أن الثاعر في عصر المرابطين أصيب بالفشل كمبدع ، وبالاغتراب الروحي كغرد متميز في المجتمع •

قلت " وإذا كانت عاطفة الرغبة أو الطمع أو الرجاء ، من أكثر ضروب العاطفة التي تؤدي إلى كثرة الانتاج الشعري من حيث الغزارة والجودة ، الأمر الذي عاد بالخير الكثير على النقد الأدبي وأحكامه خاصة عند القدماء ... (؟). فإن غرض المديح(r) تحديًا دون غيره من الأغراض قد تأخرت رتبته وتلاشت قيمته بسبب عجمة الرؤساء المرابطين وسطوة الدولة الحربية الفقهية العسكرية وتشدد الفقهاء مما مثَّل معاول هدم حقيقة لفن المديح ، ولأحكامه النقدية . ألمان. - ملا ريب أن البحث يؤكد أن الاغتراب هو المفتاح الذي يجب أن نضعه في خلدنا عند الدخول لشعر وشعراء عصر المرابطين ، فكان من الطبيعي لأدباء هذه الفترة أن يُصاب الثاعر بالذهول

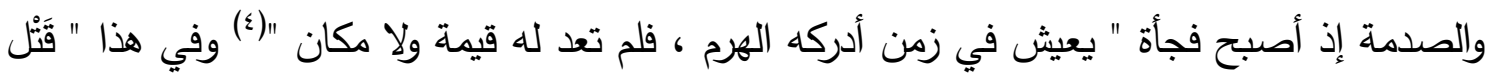
لملكة الإبداع الذاتية لاى الثاعر، أو قل قتل للإلهام وربة الثعر التي تطفح على لسان الثاعر رغمًا عنه " (0)

(') (العاطفة والإبداع الثعري دراسة في التراث النقدي عند العرب إلى نهاية القرن الرابع الهجري ، د/ عيسى علي

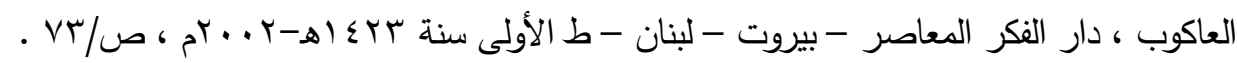

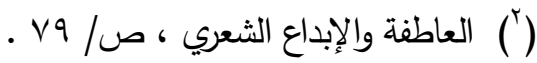

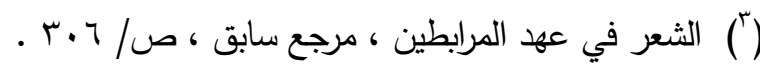

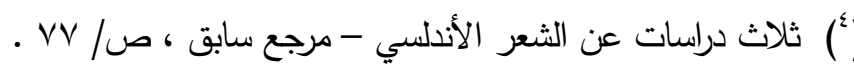

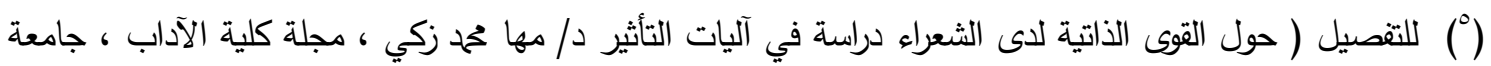

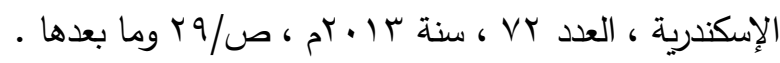


الأمر الذي يثبت أن النقلة السياسية من دولة الطوائف إلى دولة المرابطين ، كانت نقلة مُحبطة

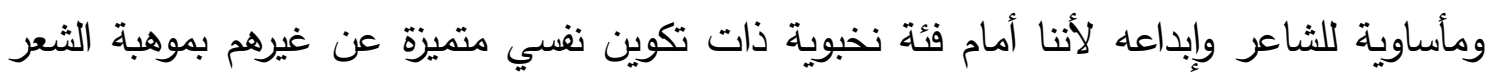
الأمر الذي جعلهم في حالة قلق دائم وتوتر مستمر يستمد زخمه من الإحساس المغترب لضياع لضياع مكانة

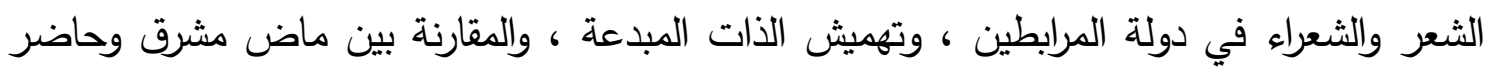

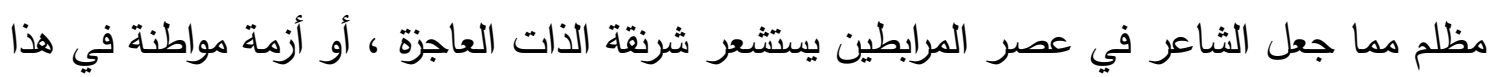
المجتمع الفقهي العسكري المتثدد دينيًا ، ومن ثم كانت علاقة الثاعر بالزمان والمكان علاقة مرفوضنة

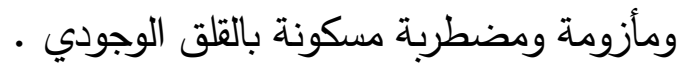




\section{الخـاتمـــة}

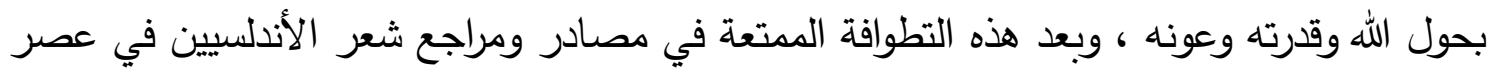

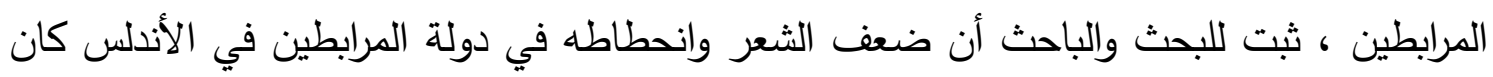

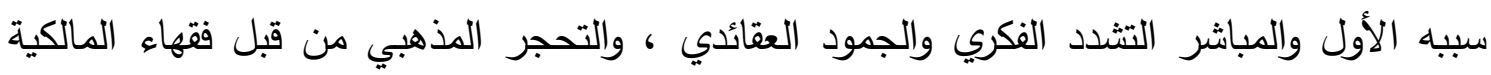

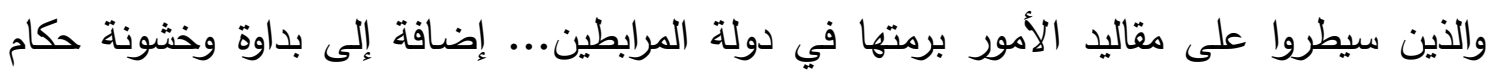

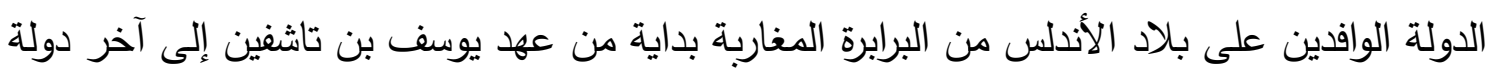

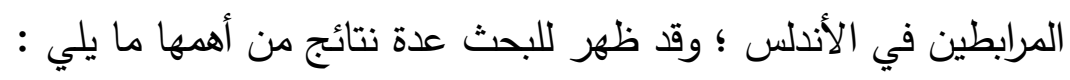

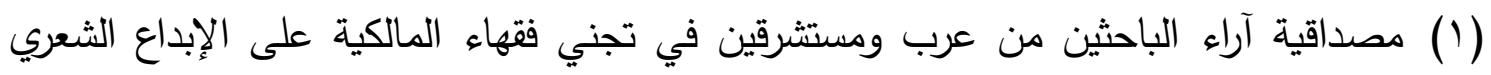

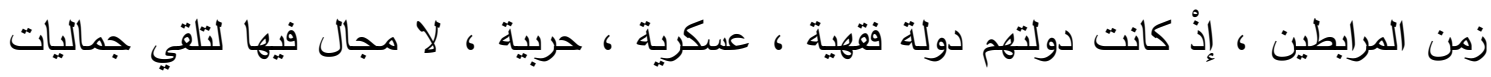

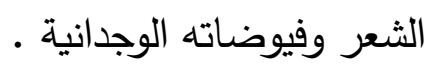

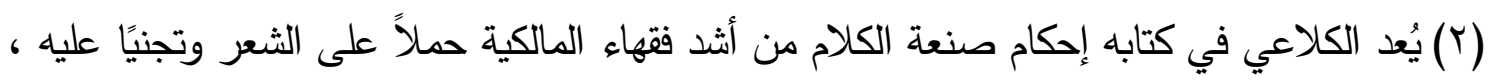

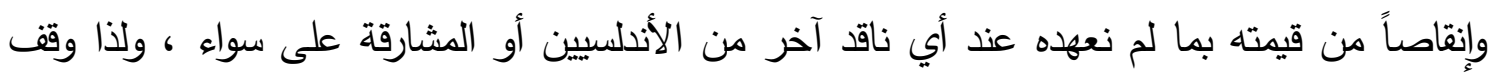
البحث معه وقفة متعجل لإثبات فكرته .

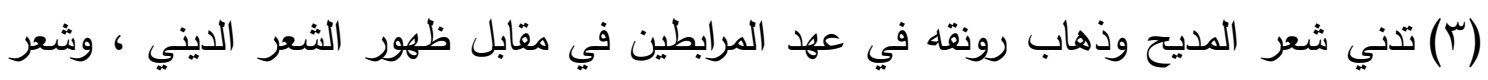
الحرب ، والثكوى ، وشعر الرثاء خاصة للمدن الزائلة على يد المرابطين في فئين.

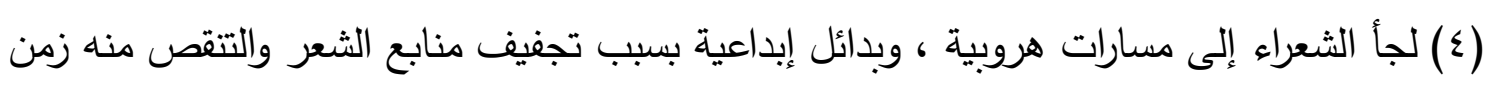

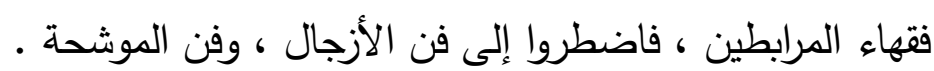

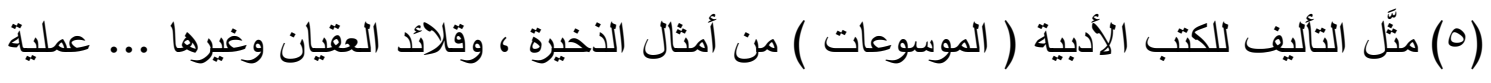

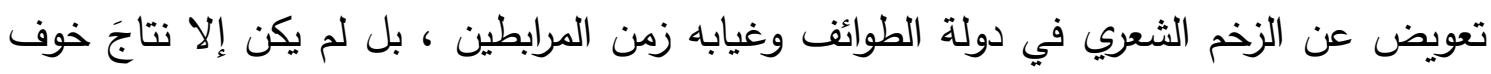

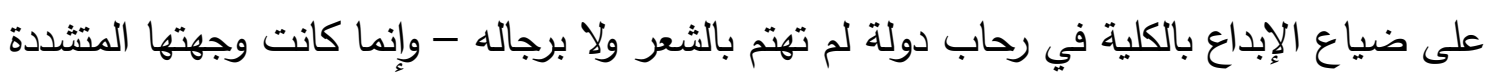
للفقه والحرب والجهاد . لإع باعل (7) فصَّل البحث مدى ضيق الأفق ، ومحدودية الفكر الإبداعي والنقدي زمن المرابطين ، الأمر

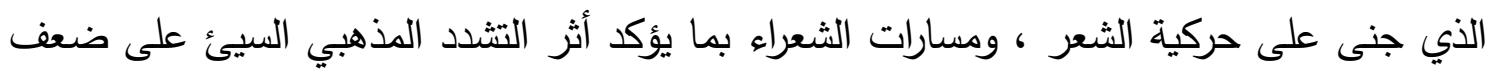

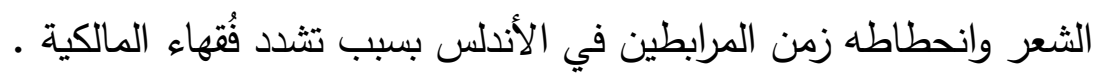

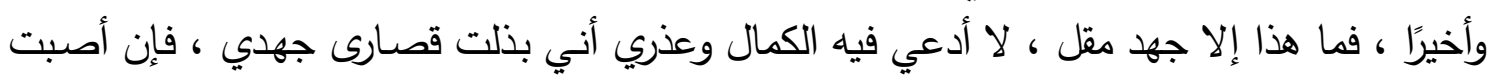

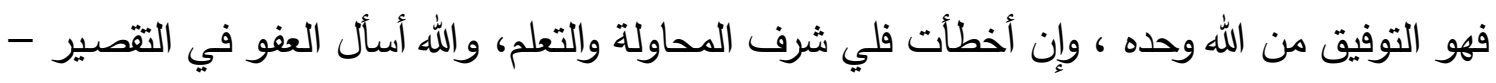

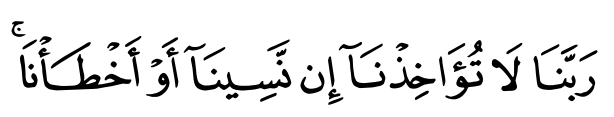

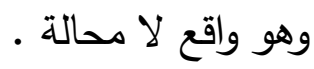

والحمد لله الذي بنعمته تتم الصالحات وصلى الله وبارك على سيدنا محمد

الباحث/ تحمد طه صالح خضر 
فهرس المصادر والمراجع

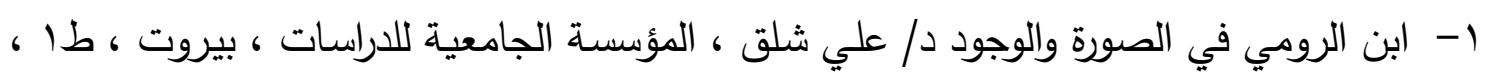

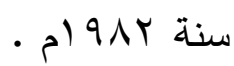

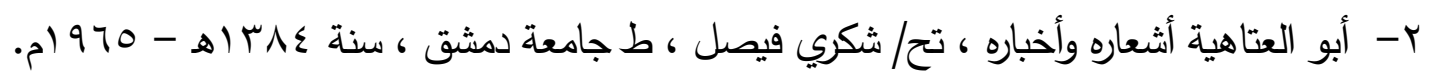

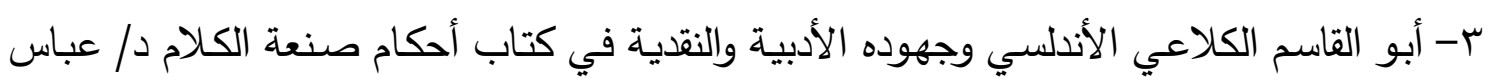

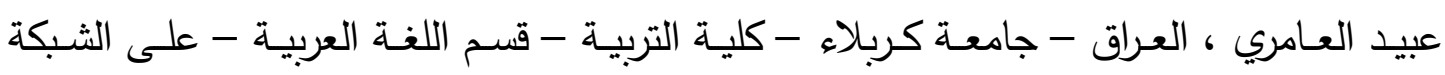

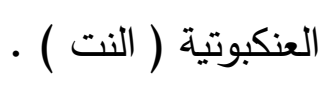

ع- الاتجاه الإسلامي في الثعر الأندلسي في عهدي ملوك الطوائف والمرابطين د/ مصطفى بهجت

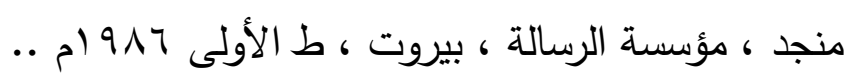

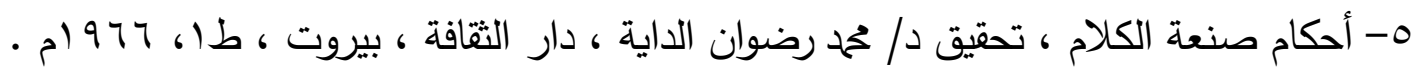

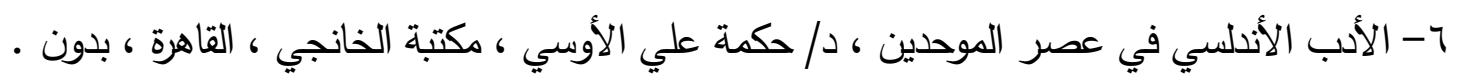

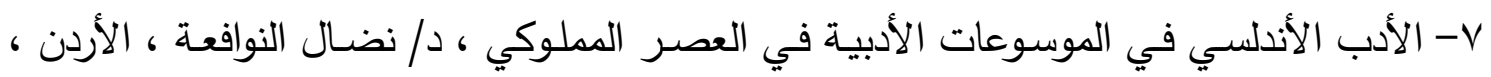

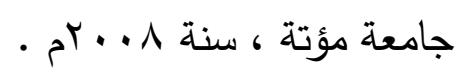

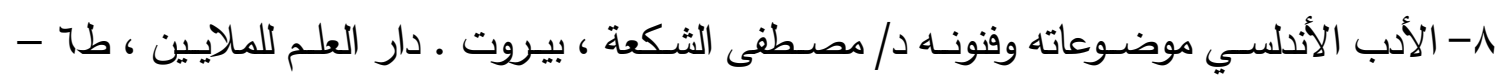
.

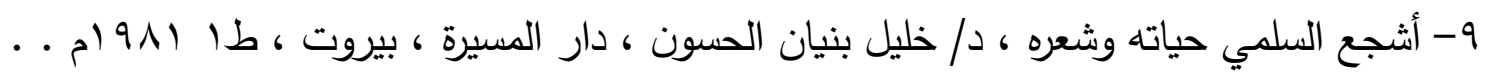

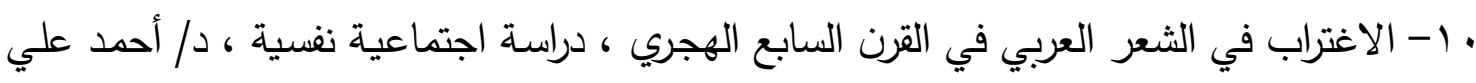

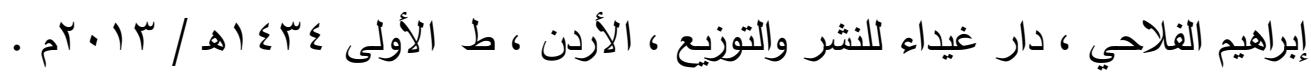

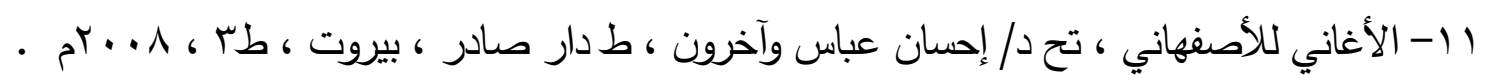

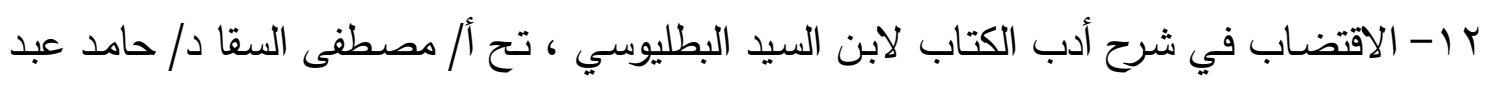

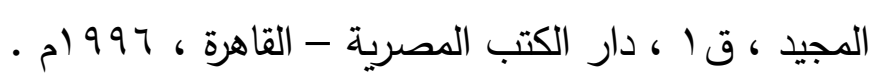

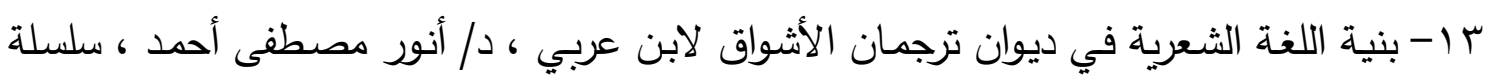

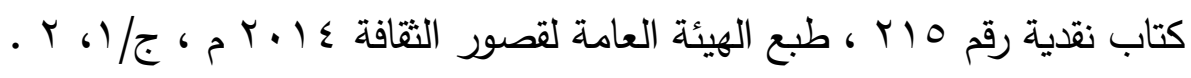

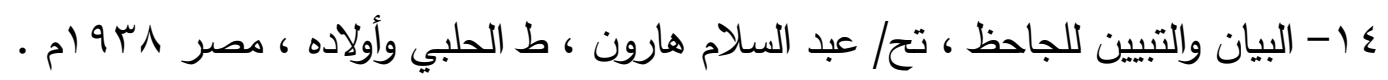

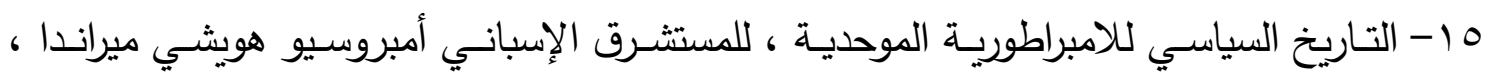

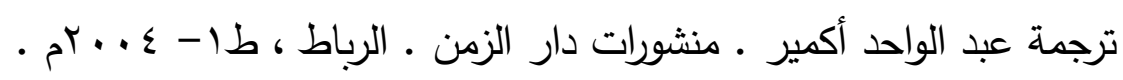

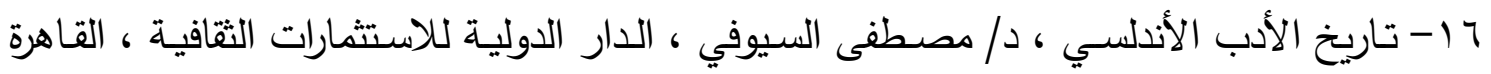
- . 


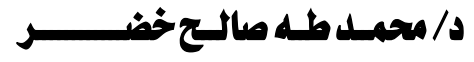

V ا تاريخ الأدب الأندلسي عصر الطوائف والمرابطين ، د/ إحسان عباس دار الثروق ، عمان ، وان

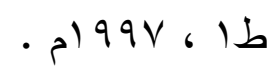

1 1- تاريخ الفكر الأندلسي آنخل جنثالث بالنثيا ، ترجمة د/ حسين مؤنس ، مكتبة الثقافة الدينية - بدون .

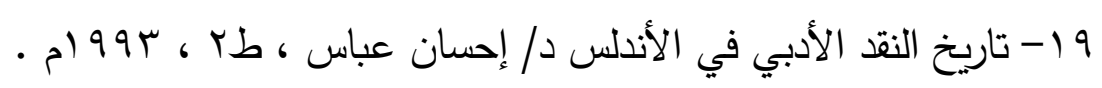

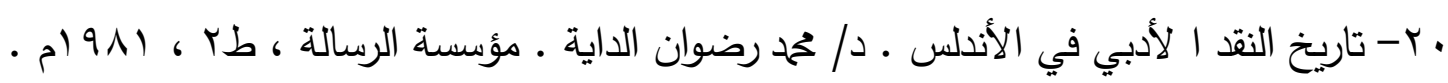

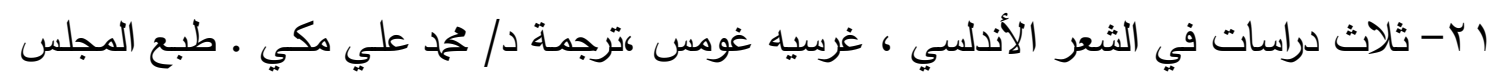

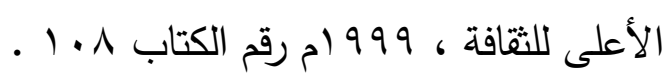

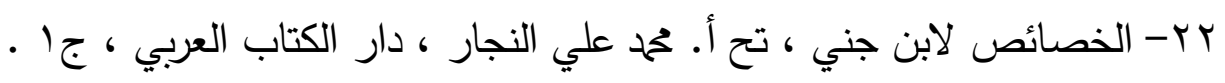

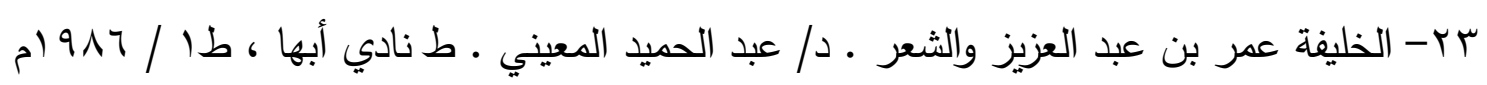

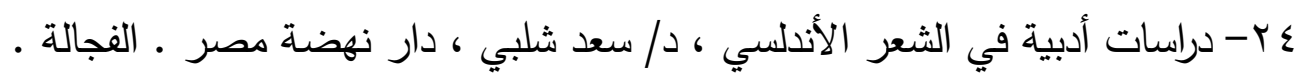

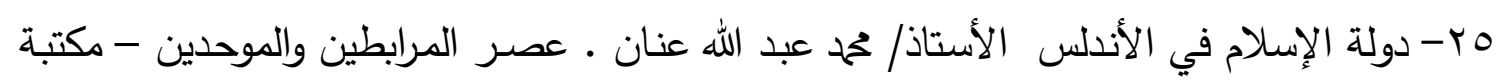

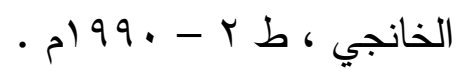

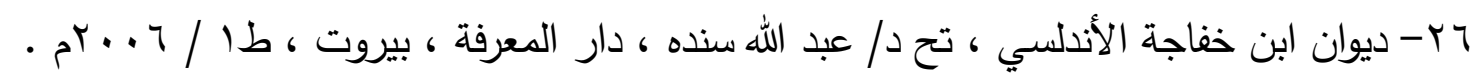

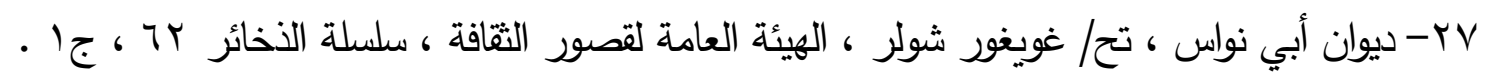

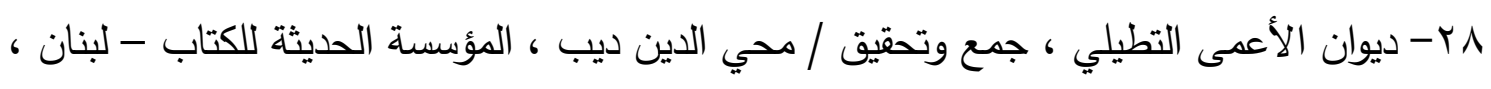
- ط

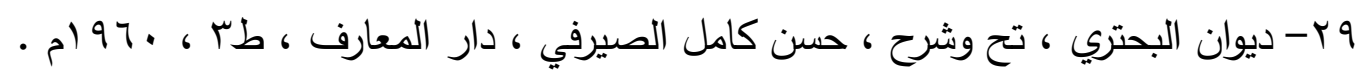

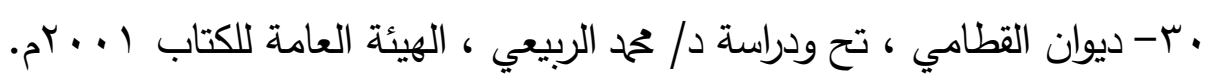

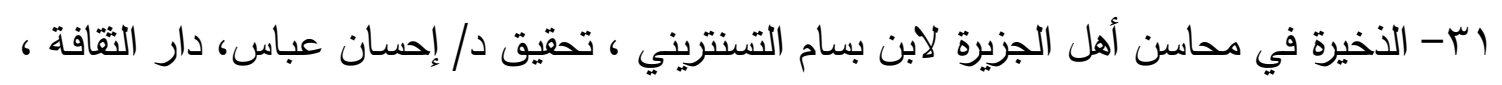

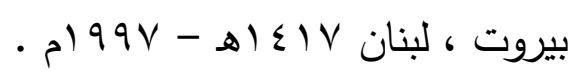

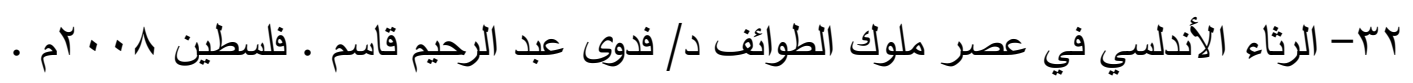

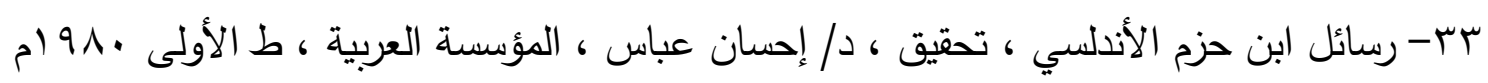

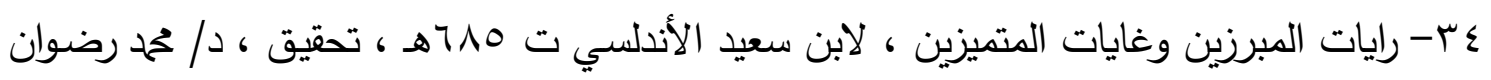

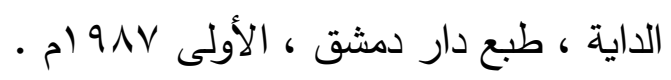

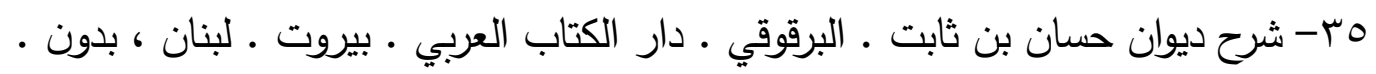

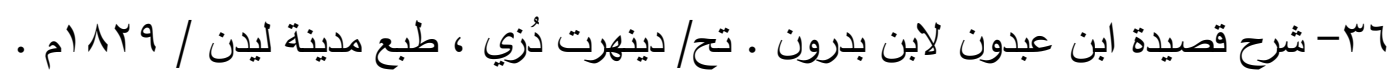

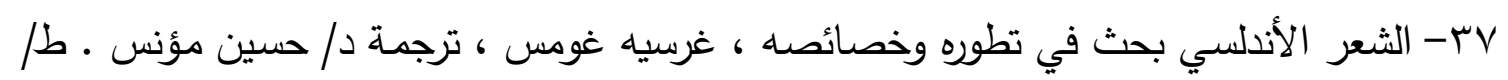

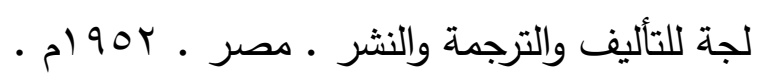


1ـ- الثـعراء الكتاب في العـراق في القرن الثالث الهجري ـ د/ حسين صـبح العـلاق ، مؤسســة

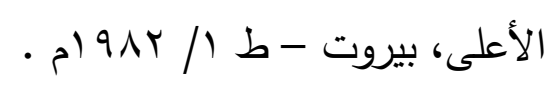

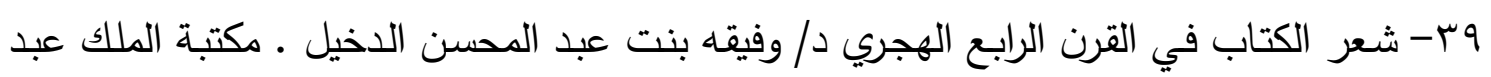

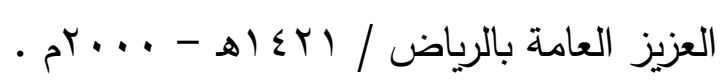

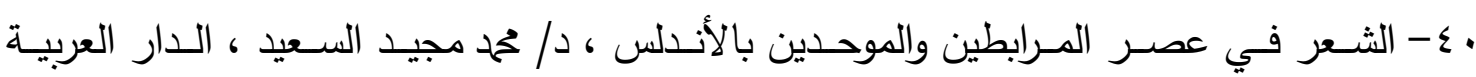

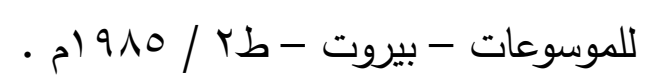

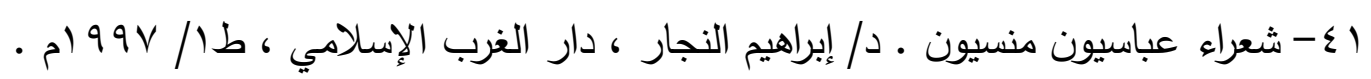

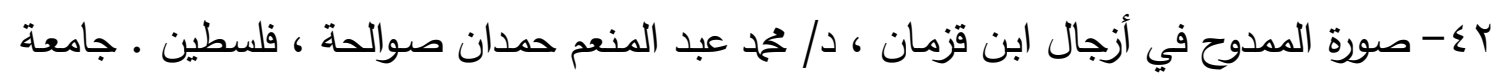

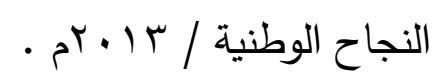

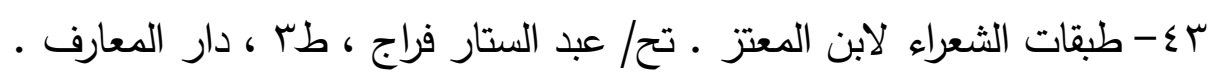

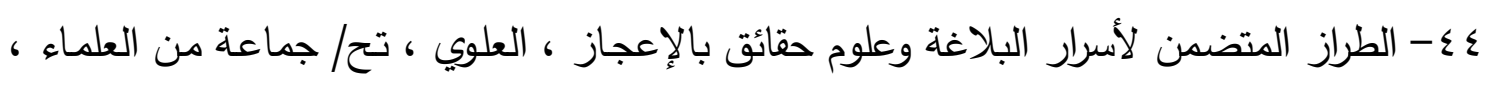

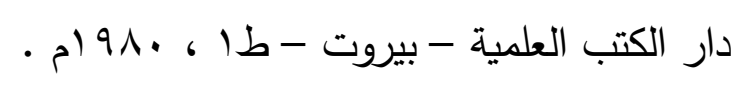

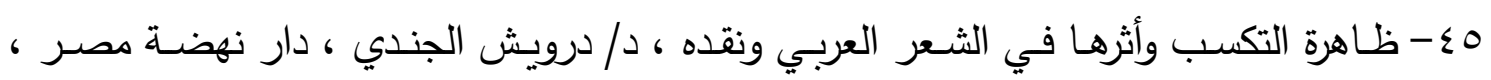
. 19V.

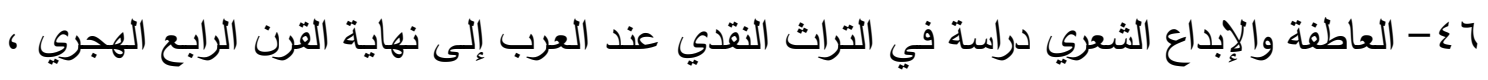

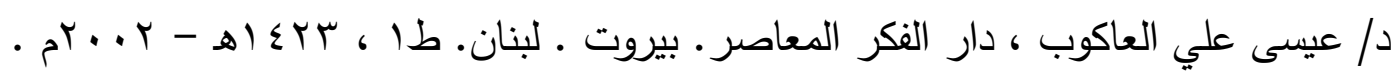

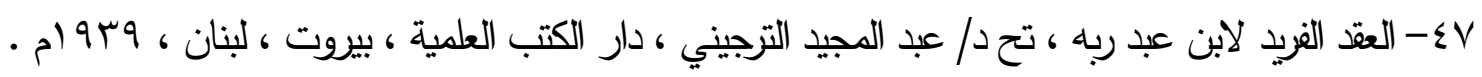

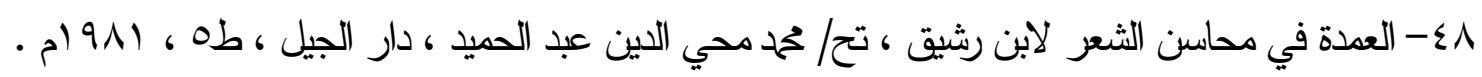

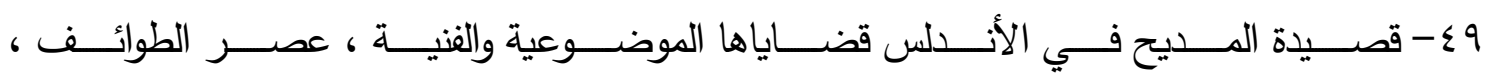

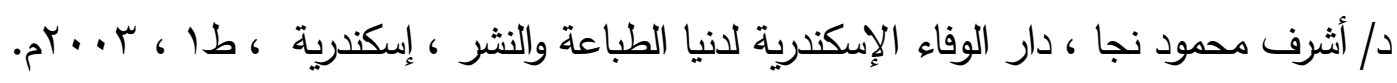

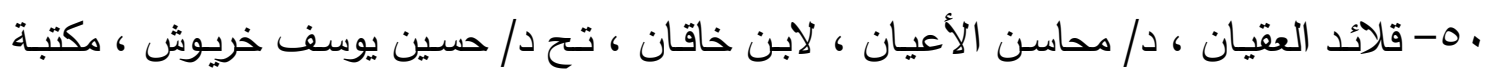

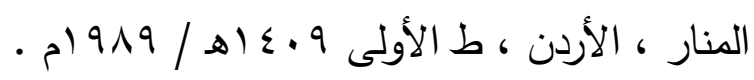

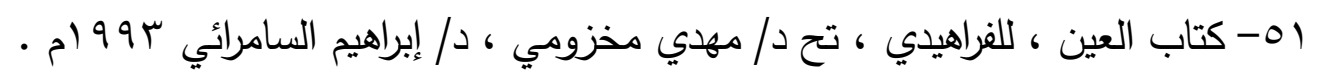

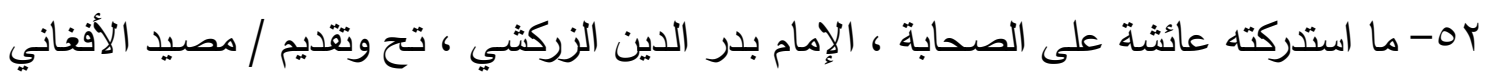

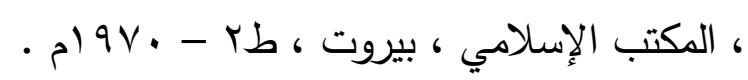

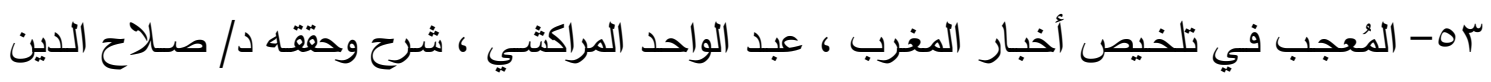

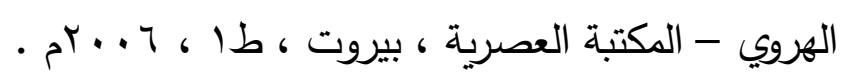

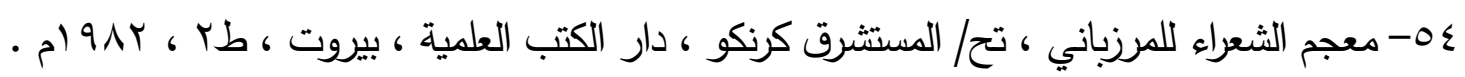




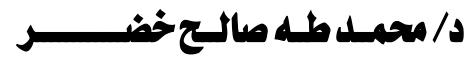

00- المُغرِب في حلي المَغرب ، لابن سيعيد المغربي ، تح د/شوقي ضيف ، دار المعارف ، ط الرابعة ، بدون - المغن

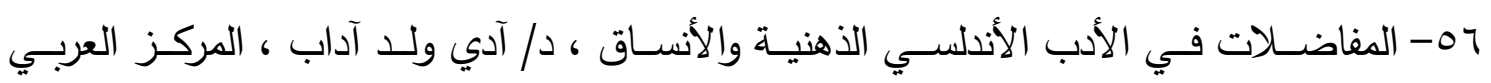

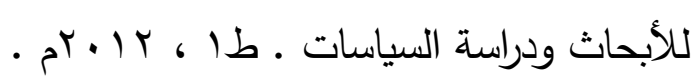

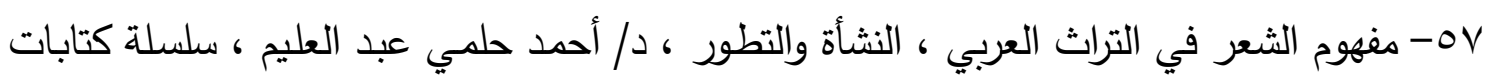

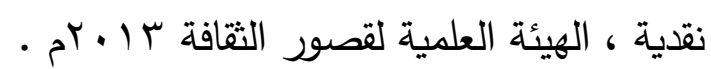

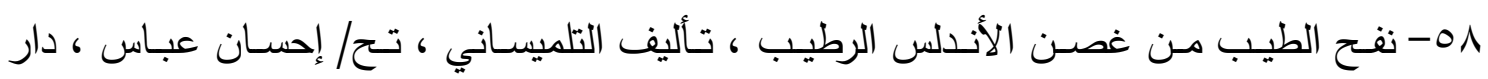

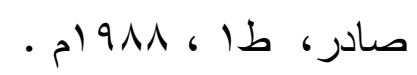

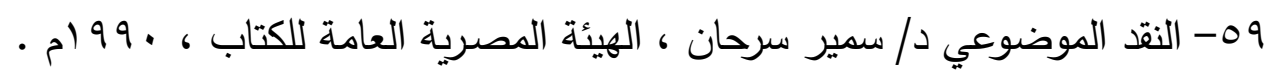

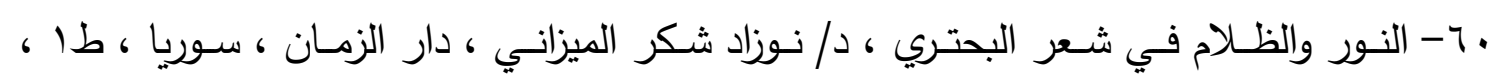

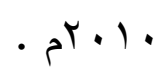

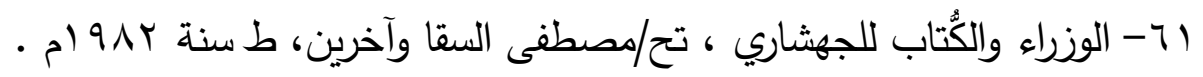

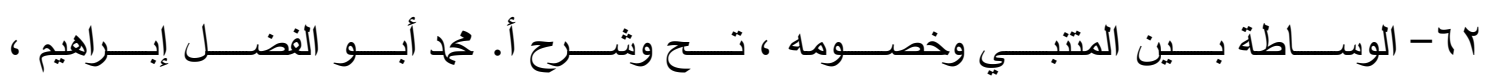

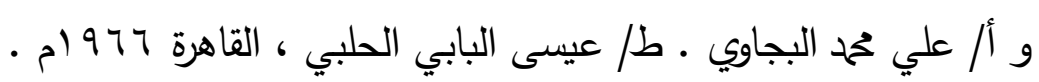

الرسائل العلمية:

1- تجربة الغرية والحنين في شعر ابن خفاجة الأندلسي ( ماجستير ) الجزائر · جامعة منتوري ،

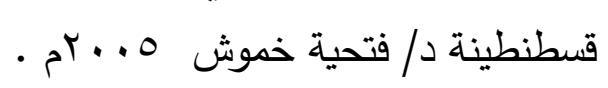

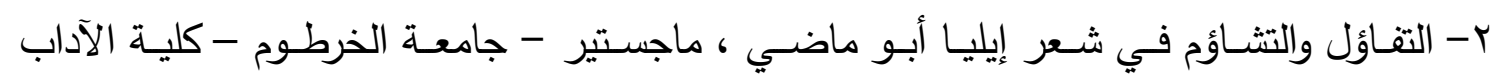

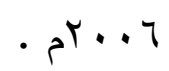

r- الجهاد في الأدب الأندلسي في عصر الطوائف والمرابطين د/ فاطمة مفلح مرشد (ماجستير )

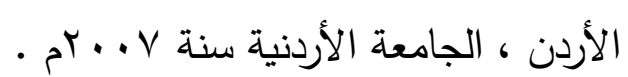

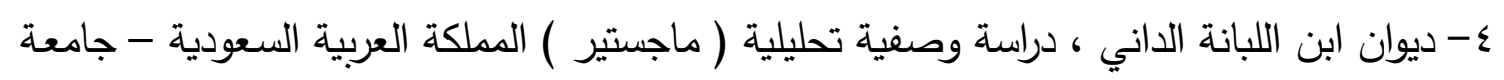
أم القرى ، عواطف الصواف لو 99 ام .

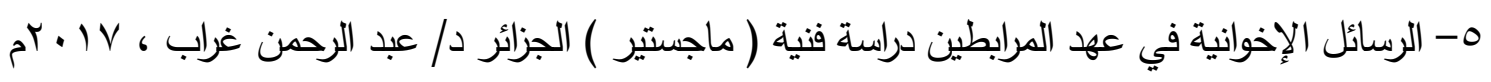

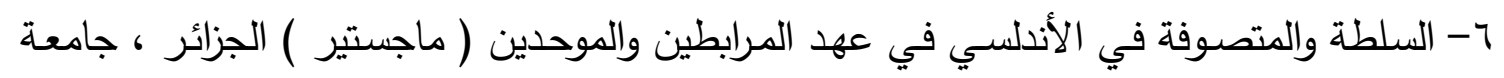

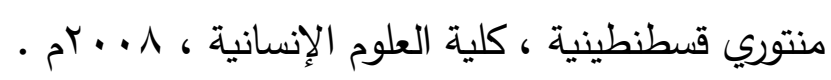

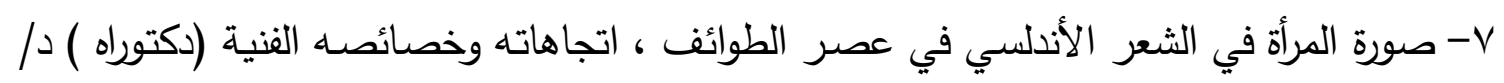

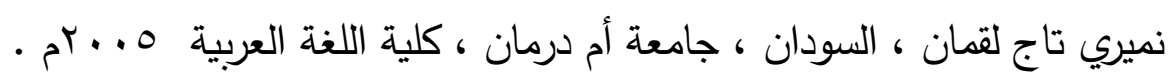


^- المعتمد بن عباد دراسة نفسية ( ماجستير ) الجزائر ، جامعة الإخوة منتوري قسطنطين ، كلية

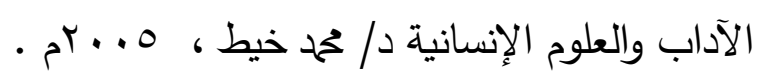

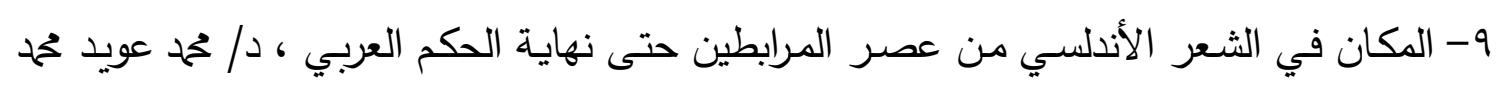

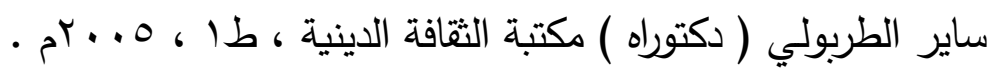

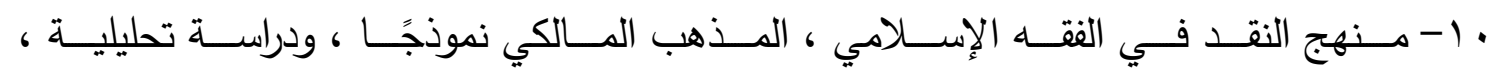

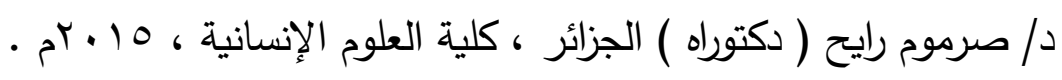

المحــالات

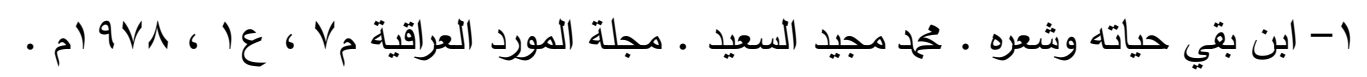

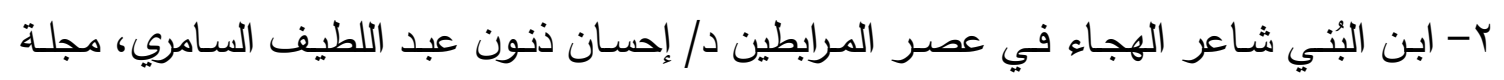

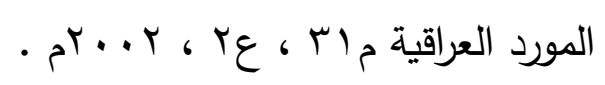

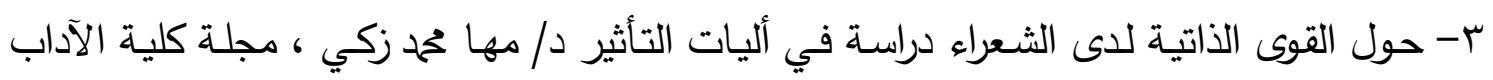

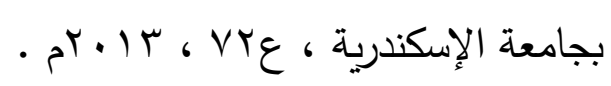

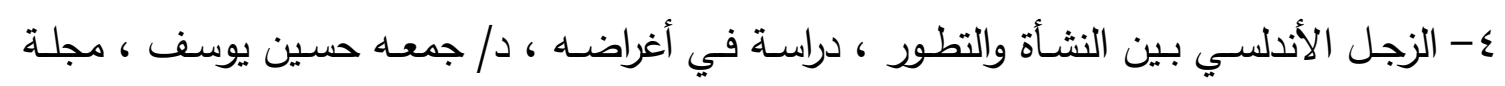

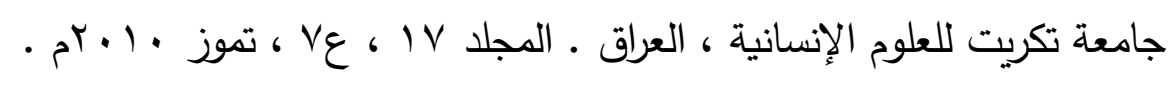

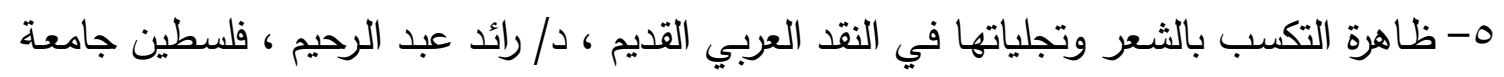

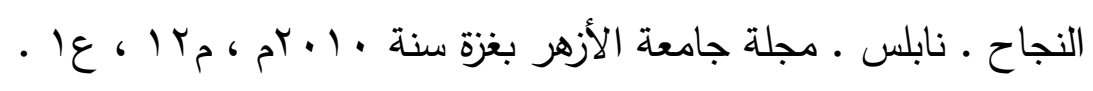

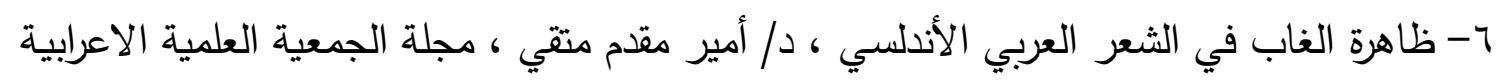

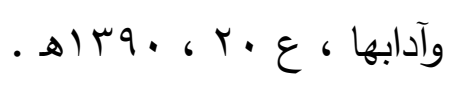

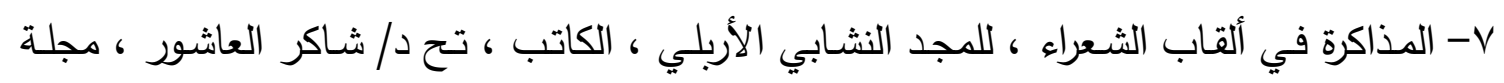

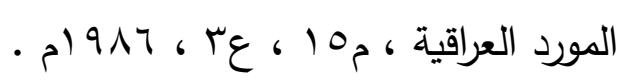

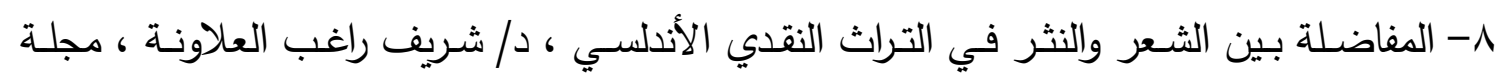

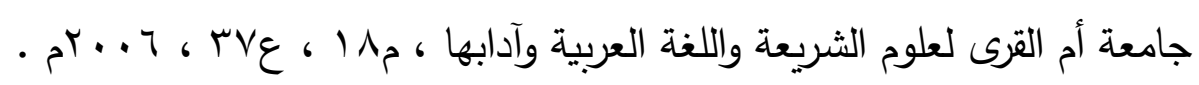

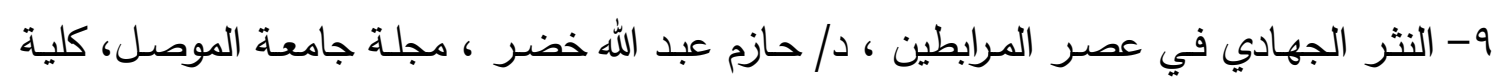

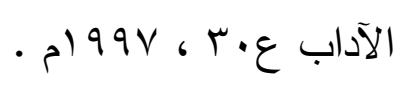


د/ محمسلدطه صالـحخ

\begin{tabular}{|c|c|}
\hline الصفحة & الموضــــــــوع \\
\hline $0 \leqslant 0$ & - المقدمـة . \\
\hline $0 \leqslant V$ & - التمهيد وفيه : التظير النقدي للفكر المتشدد في دولة المرابطين \\
\hline $0 \leqslant \vee$ & 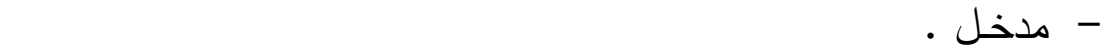 \\
\hline $0 \leq 1$ & - - بواكير الظاهرة عند ابن حزم • \\
\hline 00 & 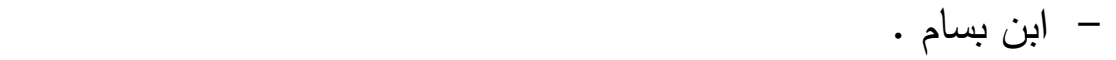 \\
\hline 001 & - ابن السيد البطليوسي • \\
\hline oor & ب - نقد فكر وليس نقد أشخاص • \\
\hline $00 \leqslant$ & ج - النقد الفقهي للتشدد المذهبي عند فقهاء المرابطين . \\
\hline 007 & هـ - شعراء دولة المرابطين هم بالأصل شعراء دولة الطوائف . \\
\hline 009 & المبحثقاث الأول : الكلاعـي وكتابـه ( الأحكـام في صـنـعة الكـلام نموذجًا \\
\hline 009 & المطلب الأول : حول الكتاب . \\
\hline $07 r$ & المطلب الثاني : الدين ضد الشعر • \\
\hline $07 \varepsilon$ & المطلب الثالث : التكسب بالمديح • \\
\hline 071 & المطلب الرابع : تعدي الضرر الأدبي من الشعر للنقد . \\
\hline 079 & المطلب الخامس : الادعاء بتتافر الشعر والكتابة . \\
\hline OVY & المطلب السادس : السجع عيب في الثعر \\
\hline ov $\varepsilon$ & المبحر الثاني : تداعيات التشدد المذهبي وأثرها على حركة الثعر زمن \\
\hline ov $\varepsilon$ & المطلب الأول : الشعراء وحس الاغتراب . \\
\hline $0 \wedge$. & المطلب الثاني : الهجرة المكانية . \\
\hline $0 \wedge$. & المطلب الثالث : الهروب للثعر الثعبي بدلاً عن الرسمي • \\
\hline ON & المطلب الرابع : التأليف في تاريخ الأدب بدافع الخوف من ضياع الشعر \\
\hline $0 \wedge 0$ & المبحث الثالث: أثر التشدد المذهبي على الأغراض الثعرية والعاطفة زمن \\
\hline $0 \wedge 0$ & مدخل : \\
\hline
\end{tabular}




\begin{tabular}{|c|c|}
\hline 010 & المطلب الأول : شعر المديح وأغراض أخرى . \\
\hline ONV & المطلب الثاني : كثرة هجاء الحكام ورجال الدولة . \\
\hline 09 . & المطلب الثالث : فن الرثاء . \\
\hline 094 & المطلب الرابع : وصف الطبيعة . \\
\hline 097 & المطلب الخامس : الشعر الديني . \\
\hline 091 & المطلب السادس : العاطفة الثعرية عند شعراء دولة المرابطين • \\
\hline ฯ. & - الخاتمــة وأهم النتائج . \\
\hline $7 \cdot 1$ & - فهرس المصادر والمراجع • \\
\hline 7.7 & - فهرس الموضوعات . \\
\hline
\end{tabular}

